\title{
Hydrogen Program Summary Fiscal Year 1994
}

Hydrogen Program Office Industrial Technologies Division National Renewable Energy Laboratory

National Renewable Energy Laboratory 1617 Cole Boulevard

- Golden, Colorado 80401-3393

A national laboratory of the U.S. Department of Energy Managed by Midwest Research Institute for the U.S. Department of Energy under contract No. DE-AC36-83CH10093 


\section{NOTICE}

This report was prepared as an account of work sponsored by an agency of the United States government. Neither the United States government nor any agency thereof, nor any of their employees, makes any warranty, express or implied, or assumes any legal liability or responsibility for the accuracy, completeness, or usefulness of any information, apparatus, product, or process disclosed, or represents that its use would not infringe privately owned rights. Reference herein to any specific commercial product, process, or service by trade name, trademark, manufacturer, or otherwise does not necessarily constitute or imply its endorsement, recommendation, or favoring by the United States government or any agency thereof. The views and opinions of authors expressed herein do not necessarily state or reflect those of the United States government or any agency thereof.

Available to DOE and DOE contractors from:

Office of Scientific and Technical Information (OSTI)

P.O. Box 62

Oak Ridge, TN 37831

Prices available by calling (615) $576-8401$

Available to the public from:

National Technical Information Service (NTIS)

U.S. Department of Commerce

5285 Port Royal Road

Springfield, VA 22161

(703) $487-4650$ 


\section{DISCLAIMER}

Portions of this document may be illegible in electronic image products. Images are produced from the best available original document. 


\section{Table of Contents}

Hydrogen Program Summary $\ldots \ldots \ldots \ldots \ldots \ldots \ldots \ldots \ldots \ldots \ldots$

Management Support $\ldots \ldots \ldots \ldots \ldots \ldots \ldots \ldots \ldots \ldots \ldots \ldots \ldots \ldots$

Technology Transfer $\ldots \ldots \ldots \ldots \ldots \ldots \ldots \ldots \ldots \ldots \ldots \ldots$

Technology Development and Validation $\ldots \ldots \ldots \ldots \ldots \ldots \ldots \ldots$

Production $\ldots \ldots \ldots \ldots \ldots \ldots \ldots \ldots \ldots \ldots \ldots \ldots \ldots \ldots \ldots \ldots \ldots \ldots \ldots \ldots \ldots \ldots$

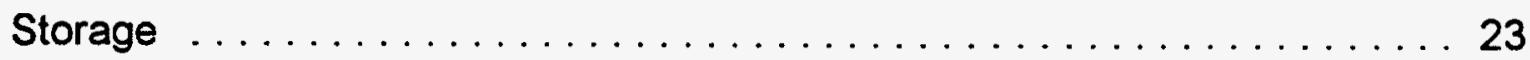

Utilization $\ldots \ldots \ldots \ldots \ldots \ldots \ldots \ldots \ldots \ldots \ldots \ldots \ldots \ldots \ldots \ldots \ldots \ldots \ldots$

System Studies $\ldots \ldots \ldots \ldots \ldots \ldots \ldots \ldots \ldots \ldots \ldots \ldots \ldots \ldots \ldots$

Life Cycle Cost Analysis $\ldots \ldots \ldots \ldots \ldots \ldots \ldots \ldots \ldots \ldots$

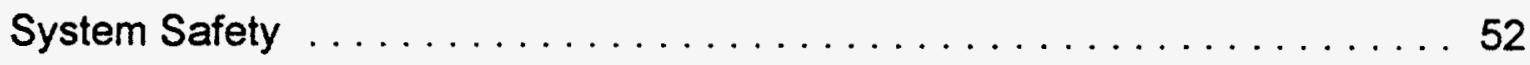

Market Analysis and Assessment $\ldots \ldots \ldots \ldots \ldots \ldots \ldots \ldots \ldots$ 


\section{Hydrogen Program Summary \\ Fiscal Year 1994}

\section{Purpose of Document}

The annual program summary provides stakeholders within the hydrogen community with a snapshot of important advances that have occurred in the National Hydrogen Program over the fiscal year, including industry interactions and cooperation. The document will also be used to encourage additional potential industrial partners to join the Hydrogen Program team.

\section{Background}

The U.S. Department of Energy (DOE) initiated the Hydrogen Program in the mid-1970's following the OPEC oil embargo, as a means to enhance energy diversity and to mitigate possible future energy supply shocks. The early program was driven by the need for energy resources that were free from foreign control, and the desire to develop a domestically based, sustainable energy economy. Hydrogen produced from domestic renewable resources would reduce energy imports and provide a sustainable energy supply. The program initially focused on the production of hydrogen from inexpensive nuclear-derived electricity. As environmental and safety concerns and the cost of nuclear energy mounted, and analysis indicated that hydrogen as a fuel was not economically competitive, the focus of the Program shifted to hydrogen as an energy carrier. This included addressing the need for storage of intermittent, renewable resources such as solar and wind. Additional benefits of hydrogen as an energy carrier have been identified by the more recent focus on air and water pollution and global warming.

The Hydrogen Research, Development, and Demonstration Act of 1990, often referred to as the Matsunaga Act, directed the Department of Energy to prepare a comprehensive five-year program management plan for hydrogen research and development, with renewable energy as the primary source for the production of hydrogen, and to develop a technology assessment and transfer program among other federal agencies. To meet these requirements, the Five-Year Plan for the Hydrogen Program was published in June 1992, and the Hydrogen Program Implementation Plan was published in October 1993. The Matsunaga Act also established the Hydrogen Technical Advisory Panel (HTAP), which provides advice to the Secretary of Energy on the Hydrogen Program. The Panel is appointed by the Secretary of Energy and consists of representatives from industry, universities, professional societies, government labs, financial, environmental, and other appropriate organizations. HTAP reviews and makes any necessary recommendations to the Secretary on the implementation and conduct of the Program; the economic, technical, and environmental consequences of the deployment of hydrogen production and use systems; and improvements to the comprehensive five-year plan.

The Energy Policy Act (EPACT) of 1992 supplemented the Matsunaga Act by requiring the assessment and development of hydrogen production from renewables, systems for hydrogen storage that may be suitable for electric vehicles powered by fuel cells, natural gas pipelines to carry hydrogen, and other R\&D programs as deemed necessary by DOE.

\section{The Year in Review}

Fiscal year 1994 marked a turning point for the Hydrogen Program, with a budget that grew significantly ( $\$ 10$ million in FY94 compared to approximately $\$ 4$ million in FY93). The focus of the Program was broadened to include development of hydrogen production technologies using municipal solid waste (MSW) and biomass, in addition to an increased emphasis on industrial involvement and near-term demonstration projects. In order to maintain its near- and long-term balance, the Hydrogen Program will continue with basic, fundamental research that provides the long-term, high-risk, high-payoff investment in hydrogen as an energy carrier.

Technology transfer and industry outreach have also received renewed attention. The National Hydrogen Association (NHA) completed an industry survey of major hydrogen producers for information on the hydrogen 
market. The DOE and NREL, in partnership with NHA, have implemented an outreach program to meet with the leaders of industries who could benefit from technology development and demonstration. In addition, an effort is now underway to educate the general public through informational brochures, videos, high school and college curricula, and publications.

\section{Programmatic Activities}

The Hydrogen Technical Advisory Panel (HTAP) met twice during FY94. At the March meeting, the committee reviewed the recommendations of the subcommittee on aircraft, reviewed and commented on hydrogen vehicles of the future, and reviewed the DOE demonstration program options. In addition, a new chairman was elected (Patrick Takahashi, HNEI). Dr. Takahashi assumed the chair in September, with new members actively participating in the meeting. Four subcommittees were established to provide recommendations for: a demonstration program; sustainable energy research and development centers; the budget and program structure; and technology requirements for applications.

The U.S. and Switzerland took lead roles in reinvigorating the International Energy Agency (IEA) Hydrogen Agreement and fostering the development of several new Annexes. Annex 10 (Advanced Production), Annex 11 (Integrated Systems), and Annex 12 (Hydrogen Storage and Transport) are supported by members of the Hydrogen Team.

Working groups are being formed to provide avenues for information exchange and input to program direction and emphasis. These four groups will consist of active researchers in hydrogen production, storage, utilization, and analysis, respectively. It is anticipated that, by utilizing the existing expertise of the national labs, universities, and industry, good communication and improved interaction will be fostered, thus enabling the program to effectively use the available funding.

\section{Technical Activities}

A patent was awarded to Dr. Paul Weaver, NREL, for photoconversion of gasified organic materials. Dr. Weaver has an additional patent pending. Patent applications are being prepared or have been filed by the University of Hawaii (Antal, catalyst) and Energy Conversion Devices (Sapru, metal hydrides).

Industry involvement in the program increased with the signing of three storage subcontracts (A.D. Little, Energy Conversion Devices, and H Power). These one-year efforts have been completed or are nearing completion. Additional industry-lead projects are under development or review.

Production research continued in three areas (photobiological, photoelectrochemical, and thermochemical processes) and was concluded in solar thermal production. Significant advances have been made in each area. Research in hydrogen storage continued at a number of facilities, and included efforts in the production and characterization of carbon nanotubules, aerogels, and glass microspheres. Advances were made in the development and use of computer models of hydrogen-fueled engines. Analysis work also continued, with additional efforts directed toward life-cycle cost studies and pathway analysis.

Hydrogen researchers presented technical results at numerous conferences, many of which had large international audiences. A number of papers were accepted for publication in refereed journals. Researchers were invited to participate in workshops and as speakers at technical conferences.

\section{Program Structure}

The Hydrogen Program consists of three program areas, in addition to program management. The number of projects in each program area in FY94 is shown below in parentheses.

- Technology Development and Validation

- Production

- Photobiological (5)

- Photoelectrochemical (2) 


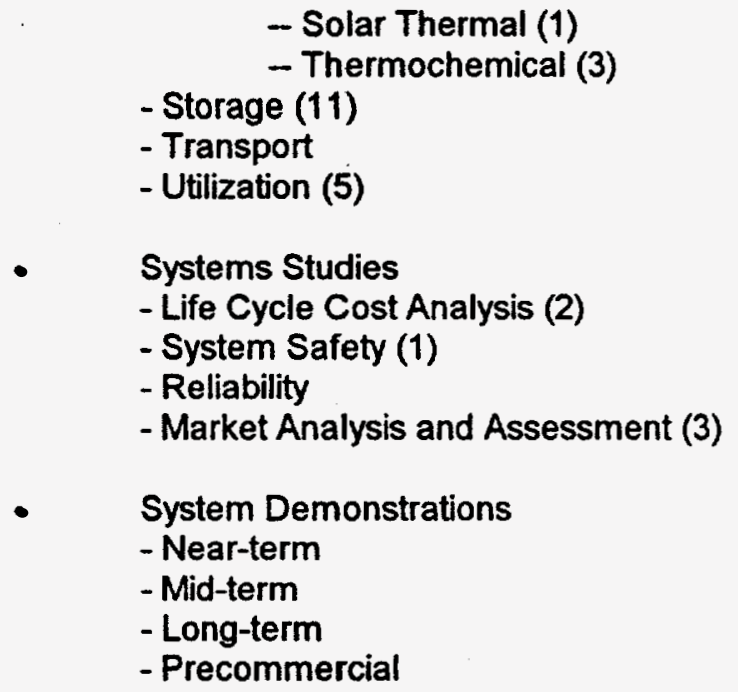

\section{Program Participants}

The Hydrogen Program counts as members of its team universities, national laboratories, private industry, and a number of consultant groups. These constituents bring a variety of skills and expertise to the program. Program participants include:

- National Laboratories

- Lawrence Livermore National Laboratory

- Los Alamos National Laboratory

- National Renewable Energy Laboratory

- Oak Ridge National Laboratory

- Sandia National Laboratories

- Universities

- Princeton University

- University of Central Florida/Florida Solar Energy Center

- University of Hawaii//Hawaii Natural Energy Institute

- University of Miami/Clean Energy Research Institute

- Industry and Consultants

- A.D. Little

- Energetics

- Energy Conversion Devices

- H Power

-W. Hoagland and Associates

- Peter Hoffmann/The Hydrogen Letter

- National Hydrogen Association

\section{Program Summary Sheets}

Each funded project submitted a summary of work conducted in FY 1994. These summaries are presented in the following sections, grouped by program area. 
Management Support 


\begin{tabular}{|c|c|c|c|c|c|c|c|c|}
\hline $\begin{array}{l}\text { Task } \\
\text { Thie }\end{array}$ & \multicolumn{4}{|c|}{ Program Planning and Analysis } & Contractor & Energetics, & $\begin{array}{l}\text { Principal } \\
\text { nuestiontor }\end{array}$ & Joseph S. Badin \\
\hline \multirow{2}{*}{$\begin{array}{l}\text { Task } \\
\text { Funding } \\
\text { (KS) }\end{array}$} & FY91 & FY92 & FY93 & FY94 & \multirow{2}{*}{$\begin{array}{l}\text { Hydrogen } \\
\text { Program } \\
\text { Area }\end{array}$} & \multirow{2}{*}{$\begin{array}{l}\text { Management } \\
\text { Support }\end{array}$} & \multirow[t]{2}{*}{ Researchers } & \multirow{2}{*}{$\begin{array}{l}\text { Phil DiPietro } \\
\text { George Kervitsky } \\
\text { Ed Skolnik }\end{array}$} \\
\hline & 0 & 0 & 0 & 150 & & & & \\
\hline
\end{tabular}

Objective:

To provide analytical and technical management support to assist the Program Manager of the Hydrogen Energy Program within the Office of Energy Management. To prepare drat documents, briefings, and program review summaries; support technical and analytical studies; gather and refine data; and coordinate activities with other related DOE programs. To represent and support the program in activities associated with industry outreach, interagency coordination, system studies integration, the Hydrogen Technical Advisory Panel (HTAP), and the International Energy Agency Agreement.

Approach/Background:

The DOE Hydrogen Energy Program is planning near-term activities to build an experience and knowledge base that will allow the transitional and large-scale introduction of hydrogen into the national energy mix by funding a portfolio of research and development projects aimed at minimizing technology risks, establishing priorities for R\&D and demonstration that reflect the needs of the private sector. The program also coordinates activities with other federal agencies and the International community, and communicates program objectives, direction, activities, and other related information to stakeholders so that program goals can be achieved.

The development and distribution of program planning documents are important for the management and outreach functions of the Hydrogen Program. The Hydrogen implementation Plan FY 1994-1998, October 1993, is a key planning document for the program. It incorporates the programs historical overview, mission, and vision. The status of R\&D activities, program strategy, goals, planning activities, assumptions, and milestones were reviewed and refined for inclusion in the document. A rigorous review of the document was conducted and comments and suggestions from the National Laboratories, HTAP, and key industry representatives were incorporated into the document's final draft.

The Annual Hydrogen Program Review meeting assists in program management and provides the DOE Program Manager the opportunity to evaluate the technical progress, approach, rationale, and technology transfer efforts of funded projects. This "peer" review draws upon the expertise of both government and industry reviewers. A scoring system was developed that enables reviewers to score projects based on technical achievement, approach, progress, and other categories of merit. Project summaries collected from all program-funded R\&D projects were used to generate reviewer workbooks and participant notebooks. Scores and comments gathered from the reviewers were synthesized and used to produce a review panel report and recommendations.

Additional programmatic planning activities are accomplished by the Hydrogen Program System Studies program element through the activities of the System Studies Coordination Group. Consisting of the principal investigators funded by the Hydrogen Program, this group conducts periodic meetings to review the status of currently funded system studies and to discuss future activities and assessment priorities. Meetings are planned, process agendas developed, and materials are prepared as needed to facilitate the coordination meetings and support the activities of the System Studies program element Project Manager.

The successful commercial development of practical hydrogen technologies and systems will be driven by market forces and not government mandate. The needs of the private sector wil be realized by private sectorindustry participation through each stage of the program and priorities will be established that reflect this involvement. DOE will foster this participation through various activities, including: cost-shared projects, technical workshops, and planning groups. Site interviews will be conducted with industry stakeholders to help identify potential demonstration projects for DOE/industry co-development, to assist in the evaluation of safety and reliability concerns, and to participate in other technology transfer meetings. DOE will continue its participation in the activities of the Hydrogen Technical Advisory Panel (HTAP) and the International Energy Agency (IEA). HTAP conducts biannual meetings to discuss and review Hydrogen related issues and to report recommendations to DOE on the implementation and conduct of the program. The biannual meetings are attended by the public and DOE representatives. Briefings and presentation materials are prepared as needed. In addition, a DOE-designated official has participated in working group meetings of the IEA in support Annex 11 activities which includes hydrogen energy system development. This involvement helped to develop the IEA Hydrogen Work Plan and the assigned attendee took responsibility for key areas in which the U.S. will lead the development of integrated hydrogen energy systems.

Proper communications between DOE and hydrogen's many stakeholders will ensure that the issues, successes, and concerns regarding hydrogen research and the development of safe, practical, and competitive hydrogen technologies and systems are responsive to the private sector. The activities of the hydrogen program are communicated to stakeholders through the use of DOE Hydrogen Program planning documents, the activities of HTAP, technical workshops, information exchange and educational programs, outreach activities, and technology transfer meetings.

Accomplishments/Status:

The development and distribution of the program planning document The Hydrogen Implementation Plan FY 1994-1998, October 1993, was a key planning document for the program. It incorporated the programs historical overview, mission, vision, status of R\&D activities, program strategy, goals, planning activities, assumptions, and milestones.

Project summaries collected from all program-funded R\&D projects were used to generate reviewer workbooks and participant notebooks for the Hydrogen Program Review. Scores and comments gathered from the reviewers were synthesized and used to produce a review panel report and recommendations. 


\begin{tabular}{|c|l|l|l|l|l|}
\hline $\begin{array}{c}\text { Task } \\
\text { Thtle }\end{array}$ & Program Planning and Analysis & Contractor & $\begin{array}{l}\text { Energetics, } \\
\text { Incorporated }\end{array}$ & $\begin{array}{c}\text { Princlpal } \\
\text { Investigator }\end{array}$ & Joseph S. Badin \\
\hline
\end{tabular}

Accomplishments/Slatus (continued):

Additional programmatic planning activities are accomplished by the Hydrogen Program System Studies program element through the activities of the System Studies Coordination Group. Consisting of the principal investigators funded by the Hydrogen Program, this group conducts periodic meetings to review the status of currently funded system studies and to discuss future activities and assessment priorities. Meetings are planned, process agendas developed, and materials are prepared as needed to facilitate the coordination meetings and support the activities of the System Studies program element Project Manager.

The successful commercial development of practical hydrogen technologies and systems will be driven by market forces and not government mandate. The needs of the private sector will be realized by private sectorindustry participation through each stage of the program and priorities will be established that reflect this imolvement. DOE will foster this partictpation through various activities, including: cost-shared projects, technical workshops, and planning groups. Site interviews will be conducted with industry stakeholders to help identify potential demonstration projects for DOE/industry co-development, to assist in the evaluation of safety and reliability concerns, and to participate in other technology transfer meetings. DOE will continue its participation in the activities of the Hydrogen Technical Advisony Panel (HTAP) and the International Energy Agency (IEA) on Task 11. HTAP conducts biannual meetings to discuss and review hydrogen-related issues and to report recommendations to DOE on the implementation and conduct of the program. The biannual meetings are attended by the public and DOE representatives. Briefings and presentation materials are prepared as needed. Additionally, a DOE-designated official, has participated in working group meetings of the IEA in support of Task 11 activities which include hydrogen energy system development. This involvement helped to develop the IEA Hydrogen Work Plan and the assigned attendee took responsibility for key areas in which the U.S. will lead the development of integrated hydrogen energy systems.

Publications/Awards:

Implementation Plan FY 1993-1997, produced by Energetics, Incorporated for U.S. Department of Energy, October 1993

Meeting Reports from Industry Outreach Meetings, prepared by Energetics, Incorporated for U.S. Department of Energy, April 1994

1994 Annual Review Participants Notebook, produced by Energetics, Incorporated for U.S. Department of Energy, April 1994

1994 Annual Review Reviewers Notebook, produced by Energetics, Incorporated for U.S. Department of Energy, April 1994

1994 Annual Review Results Analysis, prepared by Energetics, Incorporated for U.S. Department of Energy, April 1994

System Studies - Matrix/Gap Analysis, prepared by Energetics, Incorporated for U.S. Department of Energy, July 1994

Materials for Hydrogen Program System Studies Coordination Group, prepared by Energetics, Incorporated for U.S. Department of Energy, August 1994

Summary of Current System Studies, prepared by Energetics, Incorporated for U.S. Department of Energy, July 1994

Summaries of Program Outreach Meetings, prepared by Energetics, Incorporated for U.S. Department of Energy, August 1994

HTAP Briefing Materials, produced by Energetics, Incorporated for U.S. Department of Energy, October 1994

IEA Working Group Meeting Notes, prepared by Energetics, Incorporated for the U.S. Department of Energy, November-1994

Students associated with the Program (Undergraduate, Graduate, Post Doctoral):

None

Future Directions/Industry Interactions:

DOE management support on issues regarding program planning and analysis will be continued. An enhanced portfolio of program planning and information documents will be prepared to effectively communicate activities and goals. This will potentially attract greater private sector participation in the program and contribute to its successes. Coordinated interactions with other federal agencies and private sector stakeholders interested in hydrogen technology, systems, and applications will be expanded. 


\begin{tabular}{|c|c|c|c|c|c|c|c|c|}
\hline $\begin{array}{l}\text { Tack } \\
\text { Tutie }\end{array}$ & \multicolumn{4}{|c|}{$\begin{array}{l}\text { Technical Support to Hydrogen } \\
\text { Program }\end{array}$} & Contractor & $\begin{array}{l}\text { W. Hoagland \& Assoc., } \\
\text { Inc. }\end{array}$ & $\begin{array}{c}\text { Principal } \\
\text { Investigator }\end{array}$ & W. Hoagland \\
\hline \multirow{2}{*}{$\begin{array}{l}\text { Task } \\
\text { Funding } \\
\text { (K\$) }\end{array}$} & FY91 & FY92 & FY93 & FY94 & \multirow{2}{*}{$\begin{array}{l}\text { Hydrogen } \\
\text { Program } \\
\text { Area }\end{array}$} & \multirow{2}{*}{$\begin{array}{l}\text { Management Support: } \\
\text { Technology transfer }\end{array}$} & \multirow[t]{2}{*}{ Researchers } & \\
\hline & 0 & 0 & 0 & 118 & & & & \\
\hline
\end{tabular}

Objective:

The purpose of this subcontract is to procure the technical support services of W. Hoagland \& Associates in three areas:

Task 1: Technical support to DOE for the International Energy Agency Hydrogen Agreement

Task 2: Technical and management support to the U.S. Department of Energy for public education and Information transfer

Task 3: Technical and economic analysis of hydrogen production processes

\section{Approach/Background:}

Task 1: Technical support to DOE for the IEA Hydrogen Agreement includes the duties of serving as operating agent for Task 12 - Hydrogen Storage and Transport. This includes technical scope, development of work plans, reporting and participation in IEA Executive Committee and Experts Meetings.

Task 2: This task involves providing technical input to DOE's efforts in public education and outreach programs. This includes acting in an advisory capacity to other subcontractors in this area.

Task 3: This task will be to conduct brief, technical engineering feasibility analysis of electrolysis and photoconversion processes to ascertain the relevancy of current research activities and goals to the practical application of such production processes to hydrogen production for energy applications.

Accomplishments/Status:

The reinvigorated IEA Hydrogen Agreement has initiated several new annexes. Annex 12 was developed and approved at the last Executive Committee meeting. The IEA tasks will be conducted for a period of three years. The technology assessments will identify opportunities and priorities for research efforts.

All work as stated above in currently underway and will be competed by March 31, 1995.

Publications/Awards:

IEA "Final Summary Report - Hydrogen Production", October 1994

Presentation on the IEA Hydrogen Agreement and Chair of Photobiological Hydrogen Production Session at the World Hydrogen Energy Conference, Cocoa Beach, FL June 1994.

Presentation and Chairman of Hydrogen Session at IECEC Conference on Sustainable Energy, Monterey, CA, August 1994.

Students associated with the Program (Undergraduate, Graduate, Post Doctoral):

None

Future Directions/Industry Interactions:

This effort will support the DOE Hydrogen program to advance the international Energy Agency collaboration for task-shared projects and to provide technical input to the DOE public education effort for hydrogen systems. A follow-on to the technology assessments will assist in the DOE program planning. 


\begin{tabular}{|c|c|c|c|c|c|c|c|c|}
\hline $\begin{array}{l}\text { Toek } \\
\text { Tille }\end{array}$ & \multicolumn{4}{|c|}{$\begin{array}{l}\text { Information Transfer for the } \\
\text { DOENRREL Hydrogen Program }\end{array}$} & Contrector & Peter Hoffmann & $\begin{array}{l}\text { Princlpal } \\
\text { Investlgator }\end{array}$ & Peter Hoffmann \\
\hline \multirow{2}{*}{$\begin{array}{l}\text { Tack } \\
\text { Funding } \\
\text { (Kt) }\end{array}$} & FYo1 & FYO2 & FY93 & FYo4 & \multirow{2}{*}{$\begin{array}{l}\text { Hydrogen } \\
\text { Program } \\
\text { Area }\end{array}$} & \multirow{2}{*}{$\begin{array}{l}\text { Management Support: } \\
\text { Technology transfer }\end{array}$} & \multirow[t]{2}{*}{ Researchers } & \\
\hline & 0 & 0 & 41.6 & 42.6 & & & & \\
\hline
\end{tabular}

Objective:

To promote the public's awareness of the potential benefits of a hydrogen economy.

Approach/Background:

Under DOE's Hydrogen Multi-Year Plan, NREL has been assigned the task of conducting an information exchange program to disseminate hydrogen program information to laboratories, universities, other Federal agencies and private industry needing to keep abreast of hydrogen technology. The Matsunaga Act provides for the inclusion of publications for use by the public and private sectors in the information exchange program.

Accomplishments/Status:

During 1993 and 1994, NREL has contracted with "The Hydrogen Letter" for the monthly distribution of close to 350 copies - the limit set by the contract to officials in various federal and state agencies, Capitol Hill staffers, selected industry representatives, researchers and others. Since this is a large-volume contract, the contractor has agreed to a price that is slightly less than $50 \%$ of the normal subscription price of $\$ 160 / y e a r$. During that period, each issue of the newsletter has included a story covering specific NREL activities - such as meetings of the HTAP panel - or NREL-sponsored research projects related to hydrogen. The reporter has also covered and reported on, as part of the contract, four meetings in each year relevant to hydrogen energy research.

Publications/Awards:

Twelve monthly issues of The Hydrogen Letter.

Students associated with the Program (Undergraduate, Graduate, Post Doctoral):

None

Future Directions/Industry Interactions:

A new element will be added in 1995 to revise and update the 1981 book "The Forever Fuel - The Story of Hydrogen" (Westview Press, Boulder CO). Al the time of publication, the book was rated as "the book on the subject" by a publishing industry review service, Kirkus Reviews. When completed, the book is expected to be an up-to-date reference book on hydrogen energy research, applications and general status in the U.S. and abroad. 
Technology Development and Validation 


\begin{tabular}{|c|c|c|c|c|c|c|c|c|}
\hline $\begin{array}{l}\text { Taak } \\
\text { Thtle }\end{array}$ & \multicolumn{4}{|c|}{ Photobiological $\mathrm{H}_{2}$ from $\mathrm{H}_{2} \mathrm{O}$} & Contractor & NREL & Principal & P. Weaver \\
\hline \multirow{2}{*}{$\begin{array}{l}\text { Task } \\
\text { Fundling } \\
\text { (K\$) }\end{array}$} & FYS1 & FYs2 & FY93 & FYSA & \multirow{2}{*}{$\begin{array}{l}\text { Hydrogen } \\
\text { Program } \\
\text { Area }\end{array}$} & \multirow{2}{*}{$\begin{array}{l}\text { Production: } \\
\text { Photobiological }\end{array}$} & \multirow[t]{2}{*}{ Researchers } & \multirow[t]{2}{*}{ P.-C. Maness } \\
\hline & 0 & 38 & 119 & 200 & & & & \\
\hline
\end{tabular}

Objective:

The objective of the research is to produce hydrogen from water using a photosynthetic microorganism and sunlight.

Approach/Background:

Prolonged, simultaneous photoproduction of $\mathrm{H}_{2}$ and $\mathrm{O}_{2}$ from $\mathrm{H}_{2} \mathrm{O}$ has not been observed in undifferentiated photosynthetic organisms due to rapid inactivation of hydrogen-evolving enzymes by $\mathrm{O}_{2}$. A new class of bacterial hydrogenase enzyme that evolves $\mathrm{H}_{2}$ even in the presence of $\mathrm{O}_{2}$ has been found in a sub-group of photosynthetic bacteria. Genetic transfer and expression of the bacterial hydrogenase enzymes into an oxygenic photosynthetic microbe should generate a biophototytic system that will produce $\mathrm{H}_{2}$ from $\mathrm{H}_{2} \mathrm{O}$ in the absence of $\mathrm{CO}_{2}$.

Accomplishments/Status:

Oxygentolerant hydrogenase activity has been detected in twelve recently isolated strains of photosynthetic bacteria that were selected by their ability to grow under mandatory $\mathrm{H}_{2}$-producing conditions, even in the presence of air. The hydrogenase enzymes are deeply embedded in bacterial membranes, but have been partially characterized after extraction with detergents. The oxygen tolerance is retained in the purified preparations, indicating an altered, and potentially useful, change in hydrogenase structure.

Publications/Awards:

Weaver, P.F. "Photoconversion of Producer Gas into Single-Cell Protein." U.S. patent pending.

Students associated with the Program (Undergraduate, Graduate, Post Doctoral):

Seven high school biology teachers have been involved with the project as summer interns. One teacher went on to become Colorado teacher of the year. One advanced placement high school student did a science fair project. One mechanical engineer student has done pre-graduate and post-graduate work on reactor design.

Future Directions/industry Interactions:

Genetic transfer of the oxygen-tolerant hydrogenase genes will be pursued with cyanobacterial or green algal recipient hosts. Cell-free systems for the production of $\mathrm{H}_{2}$ from water are also being examined. Spin-off technologies for single-cell protein production, etc., are being examined for their potential development through private or governmental support. 


\begin{tabular}{|c|c|c|c|c|c|c|c|c|}
\hline Task & \multicolumn{4}{|c|}{ Biological Water-Gas Shift } & Contractor & NREL & Principal & P. Weaver \\
\hline \multirow{2}{*}{$\begin{array}{l}\text { Task } \\
\text { Funding } \\
\text { (K\$) }\end{array}$} & FY91 & FY92 & FY93 & FY94 & \multirow{2}{*}{$\begin{array}{c}\text { Hydrogen } \\
\text { Program } \\
\text { Ares }\end{array}$} & \multirow{2}{*}{$\begin{array}{l}\text { Production: } \\
\text { Photobiological }\end{array}$} & \multirow[t]{2}{*}{ Researchers } & \multirow{2}{*}{$\begin{array}{l}\text { A. Frank } \\
\text { P.-C. Maness } \\
\text { S. Muralidharan }\end{array}$} \\
\hline & 0 & 38 & 119 & 205 & & & & \\
\hline
\end{tabular}

\section{Objective:}

The objective of the research is to produce a pure gas stream of $\mathrm{H}_{2}$ from thermally gasified biomass using a bacterial catalyst for gas conditioning.

Approach/Background:

A novel sub-group of photosynthetic bacteria has been isolated that shift carbon monoxide into hydrogen at high rates and efficiencies in a dark reaction. Equilibrium concentrations of carbon monoxide from synthesis gas are less than $18 \mathrm{ppm}$ at near-ambient temperature and pressure conditions. The ratelimiting step is the mass transfer of the gaseous substrate into the aqueous environment of the microbes. Microbes reversibly immobilized on solid supports are being used in the absence of a bulk water phase.

Accomplishments/Status:

More than $\mathbf{4 0 0}$ strains of bacteria have been isolated from natural environments that are capable of shifting carbon monoxide into hydrogen. Rates of shift can reach $1.52 \mathrm{mmol}$ per minute per gram of celis. Planar and particulate conducting surfaces have been derivatized with electroactive groups that have positive or negative charges with a small change in imposed bias and that function to adsorb or desorb negatively charged bacteria. Adsorbed bacteria in the absence of a bulk water phase exhibit carbon monoxide shift activity for at least ten weeks. An expandable, columnar reactor design unit has been constructed.

Publications/Awards:

Weaver, P.F. and P.-C. Maness. "Photoconversion of Gasified Organic Materials into Biologically Degradable Plastics." U.S. patent No. 5,250,427 issued on October $5,1993$.

Students associated with the Program (Undergraduate, Graduate, Post Doctoral):

Four postdoctoral synthetic chemists have been associated with the project. A part-time mechanical engineering student has been involved with scale-up designs and their operation. A biology graduate student is examining ion exchange of bacteria.

Future Directions/industry interactions:

A demonstrated reversible adsorption of enzymes on derivatized electrodes can lead to electrical mediation between redox enzymes and conducting surfaces. This opens possibilities for a large variety of specific biosensors and bioelectrochemical fuel cells. Schemes for cell-free biophotolysis with hydrogen production at solar efficiencies in excess of $20 \%$ are also feasible and are being pursued. Biological plastics and singie-cell protein projects have been spun off into separate projects and proposals with considerable industrial interest. 


\begin{tabular}{|c|c|c|c|c|c|c|c|c|}
\hline Task & \multicolumn{4}{|c|}{ Photobiological Production of Hydrogen } & & Hawaii Natural & Principal & K.R. McKiniey \\
\hline \multirow{2}{*}{$\begin{array}{l}\text { Task } \\
\text { Funding } \\
\text { (K\$) }\end{array}$} & FY91 & FY92 & FYs3 & FYs & \multirow{2}{*}{$\begin{array}{l}\text { Hydrogen } \\
\text { Program } \\
\text { Area }\end{array}$} & \multirow{2}{*}{$\begin{array}{l}\text { Production: } \\
\text { Photobiological }\end{array}$} & \multirow[t]{2}{*}{ Researchers } & \multirow{2}{*}{$\begin{array}{l}\text { Ed Bylina (Task Leader) } \\
\text { K.R. McKinley } \\
\text { D. Borthakur }\end{array}$} \\
\hline & 130 & 104 & 58 & 110 & & & & \\
\hline
\end{tabular}

Objective:

Explore the potential for mydrogen production from biological sources (specifically to apply techniques of modern molecular biology toward enhanced hydrogen production in cyanobacteria.

\section{Approach/Background:}

Hydrogen production in cyanobacteria is particularly attractive because these organisms are able to generate their own source of organic substrates using light energy and use water as their ultimate source of reductant. Molecular biology approaches are being applied to understanding and increasing hydrogen production in filamentous strains of cyanobacteria. Other potential hydrogen producers are also being examined.

Accomplishments/Status:

Spinina produces tydrogen under anaerabic conditions in the dark. We have identified and established components required for the development of a genetic system for the cyanobacterium, Spirulina pecifica. These include: (1) the identification of Spinulina restriction enzymes and their corresponding modification systems, (2) determining the levels of natural resistance to antibiotics, (3) PCR amplification of the gene encoding the 16S ribosomal RNA in this strain, (4) constructing a library of Spirulina chromosomal DNA, (5) developing DNA vectors for use in Spinulina, and (6) developing physical or biological methods for introducing foreign DNA into Spinulina cells.

Publications/Awards:

None.

Students associated with the Program (Undergraduate, Graduate, Post Doctoral):

K. Gao (post-doctoral fellow)

Future Directions/Industry Interactions:

Once the genetic system is completed, it will be used to elucidate the molecular basis of hydrogen metabolism in Spirulina in order to redirect the metabolic energies of cyanobacteria toward the production of hydrogen. Future work will be directed toward expansion of the number of suitable species for hydrogen production and engineering design solutions for large scale culturing and hydrogen capture. 


\begin{tabular}{|c|c|c|c|c|c|c|c|c|}
\hline Task & \multicolumn{4}{|c|}{ Photobiological Hydrogen Production } & & Clean Energy & Principal & T. Nejat Veziroglu \\
\hline \multirow{2}{*}{$\begin{array}{l}\text { Task } \\
\text { Funding } \\
\text { (K\$) }\end{array}$} & FY91 & FY92 & FY93 & Frse & \multirow{2}{*}{$\begin{array}{c}\text { Hydrogen } \\
\text { Program } \\
\text { Area }\end{array}$} & \multirow{2}{*}{$\begin{array}{l}\text { Production: } \\
\text { Photobiological }\end{array}$} & \multirow[t]{2}{*}{ Researchers } & \multirow{2}{*}{$\begin{array}{l}\text { D. G. Baden } \\
\text { Yasuyuki Nemoto } \\
\text { Yao-Hua Luo }\end{array}$} \\
\hline & 108 & 56 & 40 & 50 & & & & \\
\hline
\end{tabular}

Objective:

In their synchronous culture experiments, Mitsui and his associates discovered that a rare strain of unicellular cyanobacterium, Synechococcus sp. strain Miami BG 043511 , exibils two distinct stages in photobiological production of hydrogen: the first characterized by high photosynthesis and low nitrogenase activity, and the second conversely marked with low photosynthesis and high nitrogenase activity. They proceeded periodically and alternatively. The objective of the present project is twofold: (a) to find the switching mechanism for change from low to high nitrogenase activity, and (b) to measure the solar to hydrogen conversion efficiency.

\section{Approach/Background:}

Synechococcus sp. strain Miami BG 043511 exhibits two distinct stages in solar energy conversion for photobiological hydrogen production: the first is characterized by high photo-synthesis and low nitrogenase activity, and the second conversely identified by low photo-synthesis and high nitrogenase activity. These two stages (represented here by $2 \mathrm{~h}$ and $12 \mathrm{~h}$ harvesting, respectively, after light on at the last light-dark periodic treatment during synchronous culture) proceed periodically and allematively. This is obviously an elegant manner leading to the survival of nitrogenase, a highly $\mathrm{O}_{2}$ sensitive enzyme, by temporally avoiding inactivation by dioxygen. However, some questions are still left to be answered: What is the mechanism or the switch for the cycle? What is the energy conversion efficiency? Experiments have been conducted to explore these issues.

\section{Accomplishments/Status:}

(1) Mechanisms of Periodic Changes in Photosynthetic Activation: Data of $\mathrm{O}_{2}$ evolution rate show that when melhylviologen and dimethyiquinone are used as electron acceptors, there is no difference between $2-\mathrm{h}$ and 12-h cells; but a significant change in $\mathrm{O}_{2}$ evolution rate occurred between the two cells when $\mathrm{CO}_{2}$ was used as electron acceptor. Therefore, it may be concluded that the shift from photosynthetic to $\mathrm{H}_{2}$ photoproduction function in the $12-\mathrm{h}$ cells is independent of electron transport.

Oxygen evolution rates of the two celis were further examined. The results indicated that the periodic changes in photosynthetic activation is independent of electron transport. The reversible deactivation of the bicarbonate transport system may be directly responsible for the alternative activation of photosynthesis of synchronously growing the strain.

(2) Effect of Calcium Ion on Nitrogenase Activity. Nitrogenase activities of synchronously cultivated cells were examined at various growth stages by acetylene reduction method with and without $20 \mathrm{mM}$ calcium chloride. The removal of calcium made no remarkable difference on activities before $11 \mathrm{~h}$ after final light on, when the activity was about $80 \%$ of its highest. But after $12 \mathrm{~h}$, cells lost activity much earlier and quicker than those in presence of calcium. Cells were harvested at $14 \mathrm{~h}$, when the dependency on calcium was the highest, and their activity was measured under strictly anaerobic condition using argon gas and thiglycolate as an $\mathrm{O}_{2}$ absorbent. Activity disappeared only in the aerobic calcium-free condition, while it was well maintained in the anaerobic calcium-free condition. This resut suggests that calcium is closely related to a protection mechanism of nitrogenase from external $\mathrm{O}_{2}$.

(3) Photoconversion Efficiency of $\mathrm{H}_{2}$ Production: In order to evaluate the feasibility of $\mathrm{H}_{2}$ production, photoconversion efficiency of $\mathrm{H}_{2}$ production was examined, using cells with high-nitrogenase activity prepared by a synchronous culture. Photoconversion efficiency was calculated to be $5.5 \%$ if only the very short period with the maximum rate of $\mathrm{H}_{2}$ production was considered. However, if the whole cycle is taken into account, then the efficiency rate was $2.6 \%$. This value is the real energy conversion efficiency of the system.

(4) Substrate Use by the Strain: Cells from the batch culture of the strain usually lost their nitrogenase activity rapidly with cell age, but it was found that the deactivation could be recovered by addition of substrates such as pyruvate, glucose, sucrose and glycerol into the cell suspension. According to these results, and the fact that $\mathrm{H}_{2}$ production occurs only in the presence of light, it can be assumed that at least Photosystem $\mathrm{l}$ is involved in the recovery of nitrogenase activity and $\mathrm{H}_{2}$ production. These processes may be similar to those in photosynthetic bacteria. If so, then can the strain also use sulfide for $\mathrm{H}_{2}$ production like photosynthetic bacteria? If so, then the removal of sulfide from the environment via biological processes could be significant.

The stimulating effect in $\mathrm{H}_{2}$ production has been confirmed by gradually increasing sulfide with immobilized cells. These results suggest that the cyanobacterium is able to increase sulfide use for $\mathrm{H}_{2}$ production with cell age. Thus, the cyanobacterium not only removes sulfide and other organic substrates from waste water, but also uses them for $\mathrm{H}_{2}$ production. 


\begin{tabular}{|c|c|c|c|c|c|}
\hline Task & Photobiological Hydrogen Production & Contractor & $\begin{array}{l}\text { Clean Energy } \\
\text { Research Institute, } \\
\text { University } \\
\text { of Miami }\end{array}$ & $\begin{array}{l}\text { Principal } \\
\text { Investigator }\end{array}$ & T. Nejat Veziroglu \\
\hline \multicolumn{6}{|c|}{ Publications/Awards: } \\
\hline \multicolumn{6}{|c|}{$\begin{array}{l}\text { Kumazawa, S. \& Mtsui, A. (1994) "Efficient Hydrogen Photoproduction by Synchronously Grown Cells of a Marine Cyanobacterium, Synechococcus sp. strain } \\
\text { Miami BG 043511, under High Cell Density Conditions", Biotech. Bioeng. 44: 854-58. }\end{array}$} \\
\hline \multicolumn{6}{|c|}{$\begin{array}{l}\text { Ikemoto, H. \& Mitsul, A. (1994) "Dlazotrophic Synchronous Growth of a Marine Unicellular Cyanobacterium, Synechococcus sp. strain Miami BG 043511, } \\
\text { Under Aerobic and Micro-aerobic/Anaerobic Conditions", Microbiology 140:2148-53. }\end{array}$} \\
\hline \multicolumn{6}{|c|}{$\begin{array}{l}\text { Nemoto, Y., Blackwelder, P., \& Mitsui, A., (1994) "Ultrastructural Changes During Synchronous Growth of Aerobic Nitrogen-fixing Marine Unicellular } \\
\text { Cyanobacterium, Synechococcus sp. strain Miami BG } 043511 .\end{array}$} \\
\hline \multicolumn{6}{|c|}{$\begin{array}{l}\text { Luo, Y.-H., \& Mitsui, A. (1994) "Hydrogen Production from Organic Substrates in an Aerobic Nitrogen-fixing Marine Unicellular Cyanobacterium", Biotech. } \\
\text { Bioeng. 44: 1255-60. }\end{array}$} \\
\hline \multicolumn{6}{|c|}{$\begin{array}{l}\text { Campbel, C., Takeyama, H., \& Mitsui, A. (in press) "The Cyclic Synthesis of Messenger RNA from the Nitrogenase nifH Gene in Synchronous Cultures of } \\
\text { the Marine Unicellular Cyano- bacterium, Synechococcus sp. strain Miami BG } 043511 \text {. }\end{array}$} \\
\hline \multicolumn{6}{|c|}{ Students associated with the Program (Undergraduate, Graduate, Post Doctoral): } \\
\hline \multicolumn{6}{|c|}{ Graduate Student - C. Campbell } \\
\hline \multicolumn{6}{|c|}{ Future Directions/industry interactions: } \\
\hline \multicolumn{6}{|c|}{ Further investigation could be focused on the following aspects: } \\
\hline - & \multicolumn{5}{|c|}{ Nitrogenase of this strain: (a) isolation and (b) nitrogenase activity measurement through ${ }^{15} \mathrm{~N}$ analysis. } \\
\hline - & $\begin{array}{l}\text { ommercial production of hydrogen: At pre } \\
\text { pensive system which can produce hy }\end{array}$ & $\begin{array}{l}\text { ydrogen proo } \\
\text { continuousi }\end{array}$ & tion under anaerobic & Jition by argon & ssing is an expensive process. A less \\
\hline
\end{tabular}




\begin{tabular}{|c|c|c|c|c|c|c|c|c|}
\hline $\begin{array}{l}\text { Task } \\
\text { Title }\end{array}$ & \multicolumn{4}{|c|}{$\begin{array}{l}\text { Hydrogen Production by } \\
\text { Photosynthetic Water Spliting }\end{array}$} & Contractor & $\begin{array}{l}\text { Oak Ridge National } \\
\text { Laboratory }\end{array}$ & $\begin{array}{l}\text { Principal } \\
\text { Investigator }\end{array}$ & Elias Greenbaum \\
\hline \multirow{2}{*}{$\begin{array}{l}\text { Tusk } \\
\text { Funding } \\
\text { (K\$) }\end{array}$} & FY91 & FY92 & Fre3 & FYoA & \multirow{2}{*}{$\begin{array}{l}\text { Hydrogen } \\
\text { Program } \\
\text { Area }\end{array}$} & \multirow{2}{*}{$\begin{array}{l}\text { Production: } \\
\text { Photobiological }\end{array}$} & \multirow[t]{2}{*}{ Researchers } & \multirow{2}{*}{$\begin{array}{l}\text { E. Greenbaum } \\
\text { J. W. Lee } \\
\text { L. Mets } \\
\text { C. V. Tevault } \\
\text { S. L. Blankinship }\end{array}$} \\
\hline & 0 & 0 & 0 & 200 & & & & \\
\hline
\end{tabular}

Objective:

The objective of this research program is the production of renewable hydrogen and oxygen via light-activated photosynthetic water splitting.

Approach/Background:

This program builds upon promising results that have been obtained in the Chemical Technology Division of Oak Ridge National Laboratory on the utilization of intact microalgae for photosynthetic water splitting. In this process, specially adapted algae are used to perform the light-activated cleavage of water into its elemental constituents, molecular hydrogen and oxygen.

Accomplishments/Status:

Sustained simultaneous photoevolution of molecular hydrogen and oxygen has been observed in mutant B4 of Chlamydomonas reinhardti. B4 lacks Photosystem I, containing Photosystem II only. The data indicate that Photosystem II is capable of spanning the potential difference between water oxidation/oxygen evolution and proton reduction/hydrogen evolution. In addition, B4 is capable of photoassimilation of atmospheric carbon dioxide. Direct kinetic time-profile experiments on $\mathrm{CO}_{2}$ uptake with mutant $\mathrm{B} 4$ and control experiments with wild-type Chlamydomonas $137 \mathrm{c}$ indicated that whereas the wildtype alga, containing both light reactions, had stable photosynthetic activity in air and anaerobiosis, photosynthesis in mutant B4 was stable under anaerobiosis only. From a practical point of view, production of hydrogen and oxygen with a single photosystem implies an increase in the nel thermodynamic conversion efficiencies of light energy into chemical energy.

Publications/Awards:

E. Greenbaum, "Photobiotechnology. Application of Photosynthesis to the Production of Renewable Fuels and Chemicals" Proc. Ind. Acad. Sci. 106, 333-342 (1994).

J. W. Lee, C.V. Tevault, S. L. Blankinship, R. Collins and E. Greenbaum, "Photosynthetic water splitting: In situ photoprecipitation of metallocatalysts for simultaneous photoproduction of molecular hydrogen and oxygen in thylakoids" Energy \& Fue/s 8,770-773 (1994).

E. Greenbaum, "Biomolecular Electronics," invited article for The Encyclopedia of Biotechnology, VCH Publishers, in press (1994).

J.W. Lee and E. Greenbaum, "Bioelectronics and Biometallocatalysis for Production of Fuels and Chemicais with Photosynthetic Water-Splitting," accepted for publication Appl. Biochem. Biotechnol. (1994).

J.W. Lee S. L. Blankinship, and E. Greenbaum, "Temperature Effect on Production of Hydrogen and Oxygen by Chlamydomonas Cold Strain CCMP1619 and Wild Type 137c," accepted for publication, Appl. Biochem. Bjotechnol. (1994).

Students associated with the Program (Undergraduate, Graduate, Post Doctoral):

J.W. Lee is an ORNL Post-Doctoral Research Associate.

Future Directions/Industry Interactions:

The objective of this program is to perform applied research and development leading to the construction of a practical photobiological reactor system that can produce renewable hydrogen and oxygen via light-activated photosynthetic water splitting. Although laboratory work is still needed on this project, industry interactions and participation are welcome. The final goal of this work is to build a cost-competitive system that can contribute to the further growth and competitiveness of the U. S. economy via the production of renewable fuels and chemicals. 


\begin{tabular}{|c|c|c|c|c|c|c|c|c|}
\hline $\begin{array}{l}\text { Task } \\
\text { Titie }\end{array}$ & \multicolumn{4}{|c|}{$\begin{array}{l}\text { Photoelectrochemical Production of } \\
\text { Hydrogen }\end{array}$} & Contractor & $\begin{array}{l}\text { Hawaii Natural } \\
\text { Energy Institute }\end{array}$ & $\begin{array}{l}\text { Principal } \\
\text { Investigator }\end{array}$ & $\begin{array}{l}\text { K.R. McKinley } \\
\text { R.E. Rocheleau }\end{array}$ \\
\hline \multirow{2}{*}{$\begin{array}{l}\text { Task } \\
\text { Funding } \\
\text { (K\$) }\end{array}$} & FY91 & FY92 & FY93 & FY94 & \multirow{2}{*}{$\begin{array}{l}\text { Hydrogen } \\
\text { Program } \\
\text { Area }\end{array}$} & \multirow[t]{2}{*}{$\begin{array}{l}\text { Production: } \\
\text { Photoelectrochemical }\end{array}$} & \multirow[t]{2}{*}{ Researchers } & \multirow{2}{*}{$\begin{array}{l}\text { R.E. Rocheleau (Task Leader) } \\
\text { Zhe Zhang } \\
\text { Ching-hua Gao } \\
\text { Eric Miller }\end{array}$} \\
\hline & 139 & 67 & 51 & 95 & & & & \\
\hline
\end{tabular}

Objective:

To develop high efficiency, stable, potentially low cost electrodes for photoelectrolysis of water using only sunlight as the energy source. Specific objectives include characterization of the electrode/electrolyte interface, identification of efficiency limitations imposed by the reactor/photoelectrode designs, and development of high efficiency photoelectrodes.

Approach/Background:

Progress in the development of an efficient system for the direct photoelectrolytic production of hydrogen from water has been limited by the high voltage required to dissociate water and the corrosiveness of the aqueous electrolytes. Loss analysis and reactor models show that high direct photoelectrolysis efficiencies (solar to hydrogen) can be obtained using multijunction solid state devices with appropriate catalytic surfaces. These designs provide greater flexibility in the photoelectrode design and a wider choice of materials to be used for protection and catalytic activation of the interface. Based on available semiconductor systems and anticipated catalyst performance, we have concluded that photoelectrodes based on low-cost multijunction amorphous silicon devices have the greatest potential of meeting USDOE efficiency goals at a reasonable cost. This program is directed toward the development of appropriate catalysts and photoelectrode structures to optimize the potential of the amorphous silicon based photoelectrodes.

Accomplishments/Status:

We have demonstrated direct solar-to-hydrogen conversion efficiencies greater than $7.5 \%$ using photoelectrodes fabricated in our laboratory. These photoelectrodes, fabricated from triple-junction amorphous silicon solar cells supplied by Solarex Thin Film Corp., with protective layers and catalysts synthesized in our laboratory. The hydrogen production rate, determined by monitoring current between anodic and cathodic surfaces, remained constant for more than 2 hours. Degradation at longer times has been attributed to loss of adhesion of the epoxies used to fabricate the structures, not degradation of the semiconductor/catalyst/electrolyte interfaces. Thin film mixed-metal oxides and Group VI-VIII metal alloys have been developed for use as anodic and cathodic catalysts respectively. These materials exhibit low overpotentials and extreme stability in the alkaline electrolytes. Current efforts are focused on measurement of evolved gases, fabrication of larger area devices, and development of a bench-scale demonstration system.

Publications/Awards:

R. E. Rocheleau, Z. Zhang, E. L. Miller, and M. Vierthaler, "Photoelectrochemical Production of Hydrogen: Engineering Loss Analysis", Hydrogen Energy Progress X, D. L. Block and T.N. Veziroglu eds., P737, 1994.

Students associated with the Program (Undergraduate, Graduate, Post Doctoral):

Eric Miller, PhD candidate, EE

Matthis Vierthaler, MS EE, May 1994

Future Directions/Industry Interactions:

Development of improved thin-film catalysts for incorporation into high efficiency structures will be continued. Energy Conversion Devices and Solarex Thin Film Corporation have collaborated by contributing unencapsulated multijunction amorphous silicon solar cells for fabrication of photoelectrodes. Continued collaboration with these firms with increased emphasis on demonstration of stable performance with larger area electrodes will be the focus of future efforts. 


\begin{tabular}{|c|c|c|c|c|c|c|c|c|}
\hline Task & \multicolumn{4}{|c|}{ Water Splitting via Direct Conversion } & Contractor & NREL & Principal & Dr. John A. Turner \\
\hline \multirow{2}{*}{$\begin{array}{c}\text { Task } \\
\text { Funding } \\
\text { (K\$) }\end{array}$} & FY91 & FY92 & FY93 & FY94 & \multirow{2}{*}{$\begin{array}{c}\text { Hydrogen } \\
\text { Program } \\
\text { Area }\end{array}$} & \multirow[t]{2}{*}{$\begin{array}{l}\text { Production: } \\
\text { Photoelectrochemical }\end{array}$} & \multirow[t]{2}{*}{ Researchers } & \multirow{2}{*}{$\begin{array}{l}\text { Dr. Shyam Kocha } \\
\text { Dr. Mark Peterson } \\
\text { Dr. Doug Arent } \\
\text { Dr. Simon Tsuo } \\
\text { Dr. D. Brent MacQueen } \\
\text { Dr. Hikmat Hilal }\end{array}$} \\
\hline & 80 & 125 & 360 & 500 & & & & \\
\hline
\end{tabular}

Objective:

The goal of this research is to develop a stable, cost effective, photoelectrochemical based system that will split water upon illumination, producing hydrogen and oxygen directly, using sunlight as the only energy input.

\section{Approach/Background:}

The photoelectrolysis of water is the process whereby light, illuminating a semiconductor, is used to split water into hydrogen and oxygen. The incident light, absorbed in a semiconductor electrode, splits water directly. This one-step monolithic system eliminates the need to generate electricity externally and subsequently feed it to an electrolyzer. Our research is directed at developing a photoelectrolysis device. We hope to accomplish our objective by: (1) judicial choice of semiconductor material; (2) surface modification to improve the energetics and stability; and (3) development of transparent and highly active catalysts. Our approach is to use the best semiconductor materials that are available, consistent with the energy requirements for a water splitting system and stability in an aqueous environment. These include III-V semiconductor systems as well as $\alpha$-silicon systems. These are the semiconductors that solid state research groups are focusing on as the next generation of high efficiency solar cells. These include single bandgap systems and multiphoton devices (tandem cells). NREL's Photovoltaic and Basic Sciences Divisions provide a state of the art resource for these materials and structures.

Accomplishments/Status:

Directed modification of a semiconductor surface for control of the energetic of the electrode/electrolyte interphase.

$10 \%$ direct conversion water splitting system based on Gain $P_{2} / G a A s$ tandem cell technology.

The design, manufacturing and testing of a mixed photovoltaic/photoelectrochemical device.

The design, fabrication and testing of an amorphous silicon based tandem cell with a protective surface layer of amorphous silicon carbide.

Publications/Awards:

Shyam S. Kocha, John A. Tumer, and A. J. Nozik, "Study of the Schottky Barrier and Determination of the Energetic Positions of Band Edges at the n- and p-type Gallium Indium Phosphide Electrode/Electrolyte Interphase" , J. Electroanal. Chem., 367, 27 (1994).

S. Kocha, M. Peterson, H. Hilal, D. Arent and J.A. Tumer, "Photoelectrochemical Based Direct Conversion Systems", Proceedings of the 1994 DOE/NREL Hydrogen Program Review, April 18-20, 1994, Livermore, California.

S. Kocha, M. Peterson, A. J. Nelson, Y. Rosenwaks, D. J. Arent and J.A. Turner, "Investigation of Chemical Wet-Etch Surface Modification of GainP, using Photoluminescence, X-ray Photoelectron Spectroscopy, Capacitance Measurements and Photocurrent-Voltage Curves", J. Phys. Chem., In Press

Students associated with the Program (Undergraduate, Graduate, Post Doctoral):

Dr. Shyam Kocha - Graduate, Post Doctoral

Dr. D. Brent MacQueen - Post Doctoral

Dr. Doug Arent - Post Doctoral

Dr. Yang Xiao - Graduate

Future Directions/Industry Interactions:

Our near term goals involve the further development of water splitting catalysts, metal colloids, and surface modification techniques for increased lifetime and efficiency of photoelectrochemical water splitting devices. Novel photoelectrolysis devices we are currently developing include mixed photovoltaic/ photoelectrochemical devices and well as advanced amorphous silicon/silicon carbide tandem cells. We are looking for industry partners who are interested in developing this technology for commercial applications. In particular we are looking to interact with solar cell manufacturers and those involved with catalytic coatings. 


\begin{tabular}{|c|c|c|c|c|c|c|c|c|}
\hline Task & \multicolumn{4}{|c|}{ Solar Thermal Hydrogen } & Contractor & NREL & Principal & Kent Scholl \\
\hline \multirow{2}{*}{$\begin{array}{l}\text { Task } \\
\text { Funding } \\
\text { (KS) }\end{array}$} & FY91 & FY92 & FY93 & FY94 & \multirow{2}{*}{$\begin{array}{c}\text { Hydrogen } \\
\text { Program } \\
\text { Area }\end{array}$} & \multirow{2}{*}{$\begin{array}{l}\text { Production: } \\
\text { Solar thermal }\end{array}$} & \multirow[t]{2}{*}{ Researchers } & \multirow{2}{*}{$\begin{array}{l}\text { Roland Pitts } \\
\text { Clark Fields } \\
\text { Al Lewandowski }\end{array}$} \\
\hline & 0 & 0 & 0 & 200 & & & & \\
\hline
\end{tabular}

Objective:

Produce large quantities of hydrogen from the dissociation of water vapor using concentrated solar energy in a process competitive with other renewable energy technologies.

Approach/Background:

Direct-thermal water-splitting is a process in which water vapor is heated until it begins to thermally dissociate. Hydrogen is produced by separating it from the other gaseous products.

The task was divided into three phases spanning a period of several years:

1) Proof of Concept - screen the most viable separation techniques based on background research and small-scale experimentation, determine the critical issues in the process, and report on proof-of-concept. This phase was designed as a go/no-go decision point for the balance of the plan.

2) Resolution of Critical lssues, Detailed Design and Analysis - test and determine the optimal separation technique from those identified in Phase I, develop a model of overall system performance.

3) Pilot Plant - identify industrial partners, design and construct a pilot plant.

Accomplishments/Status:

Small amounts of hydrogen were produced at NREL's High-Flux Solar Furnace by quenching water-dissociation product gases evolved from a hot zirconia target.

Critical issues determined under Phase I were: 1) High-temperature materials, 2) Product gas separation techniques, and 3) Solar thermal energy costs.

No recently-developed high-temperature materials capable of withstanding the oxidizing and reducing atmospheres of dissociated water vapor were located; zirconia was identified as the most likely reactor material. Given the low solar-to-hydrogen efficiencies of all the technologies studied and the relatively high costs of high-temperature, solar thermal energy, no clear path to successfully achieving DOE's goal of \$10MBtu was found.

With the completion of an August milestone and Phase I of the task, a decision was made not to pursue the technology further.

Publications/Awards:

Scholl, K., A. Lewandowski, R. Pitts, and C. Fields, "Report on Small-Scale Experimentation and Determination of Critical Issues in the Solar-Thermal Production of Hydrogen," Milestone Completion Report, August, 1994.

Students associated with the Program (Undergraduate, Graduate, Post Doctoral):

None

Future Directions/Industry interactions:

NREL research staff will stay abreast of the work being conducted in this field worldwide, but will not actively pursue the technology. 


\begin{tabular}{|c|c|c|c|c|c|c|c|c|}
\hline $\begin{array}{l}\text { Task } \\
\text { Titte }\end{array}$ & \multicolumn{4}{|c|}{$\begin{array}{l}\text { Biomass to Hydrogen via Fast } \\
\text { Pyrolysis \& Reforming }\end{array}$} & Contractor & NREL & $\begin{array}{l}\text { Principal } \\
\text { investigator }\end{array}$ & Esteban Chornet \\
\hline \multirow{2}{*}{$\begin{array}{l}\text { Task } \\
\text { Funding } \\
\text { (KS) }\end{array}$} & FY91 & FY92 & FY93 & FY94 & \multirow{2}{*}{$\begin{array}{l}\text { Hydrogen } \\
\text { Program } \\
\text { Area }\end{array}$} & \multirow[t]{2}{*}{$\begin{array}{l}\text { Production: } \\
\text { Thermochemical }\end{array}$} & \multirow[t]{2}{*}{ Researchers } & \multirow{2}{*}{$\begin{array}{l}\text { Stefan Czernik } \\
\text { Dingneng Wang } \\
\text { Margaret Mann } \\
\text { Jim Siebarth }\end{array}$} \\
\hline & 0 & 0 & 0 & 450 & & & & \\
\hline
\end{tabular}

Objective:

The goal of this work is to develop a novel thermochemical route for the production of $\mathrm{H}_{2}$ from renewables based on the use of fast pyrolysis to rupture lignocellulosics into small oxygenated molecules and their subsequent catalytic steam reforming.

Approach/Background:

Renewable biomass offers an attractive alternative to petroleum- and natural gas-derived $\mathrm{H}_{2}$. Closed-loop biomass will result in zero net carbon dioxide impact. Biomass includes wood and agricultural residues, diversified solid wastes and dedicated high production regional plantations. The challenge is to achieve $\mathrm{H}_{2}$ yields at a cost similar to that resulting from hydrocarbons. Fast pyrolysis converts biomass into a mixture of low molecular weight oxygenates with yields of typically $60 \%-65 \%$ wt of dry biomass. These oxygenates are to be used as feedstock to a steam reforming operation to generate $H_{2}$, which is separated from the $\mathrm{CO}_{2}$ by known methods. The novel aspect to be developed in this project is the key catalytic steam reforming step.

Accomplishments/Status:

A tterature review has provided a chemical understanding of the composition of the fast pyrolysis oils. They are a mixture of acids, aldehyde, and alcohols derived from the carbohydrate and lignin constituents. Major compounds are thus identified. Thermodynamic simulations have provided the equilibrium data base (steam/carbon and temperature) needed for the design of the reforming step.

Catalytic screening has been conducted using model compounds and monitoring the product gas with a mass spectrometer (MBMS). Results indicate that Ni-based alumina preparations can reform the different model compounds characteristic of the pyrolysis oils. A continuous flow tubular reactor has been constructed to carry out time-on-stream studies of different commercial catalysts as well as some improved non-commercial catalyst formulations.

A technoeconomic analysis of our biomass-to-hydrogen option shows that the production costs of $\mathrm{H}_{2}$ can be profitable in today's $\mathrm{H}_{2}$ market in niches where $\mathrm{H}_{2}$ is costed at $>1.10 \$ \mathrm{~kg}$.

Publications/Awards:

"Biomass to Hydrogen via Pyrolysis and Reforming": Chomet, E.; Czernik, S.; Wang, D.; Gregoire, C.; and Mann, M.; Proceedings of the $\mathrm{H}_{2}$ Program Review Meeting, Livermore, California, April 18-2, 1994, pp. 407-432, Document NREL/CP-470-6431.UC-1360.DE94011835.

"Biomass to Hydrogen via Pyrolysis and Reforming": Mann, M.; Czernik, S.; Wang, D.; and Chornet, E.; Paper presented at the 208th ACS National Meeting, Washington, August $21-25,1994$ (To be printed in the Preprints of the Fuel Division).

Students associated with the Program (Undergraduate, Graduate, Post Doctoral):

Undergraduate Summer (1994) Student: LeAnn Vargo, Chemical Engineering, University of Idaho

Postdoctoral: Daniel Montane, Ph.D., Univ. Rovirai Virgili, Tarragone, Catalonia, Spain

Future Directions/Industry Interactions:

Work to be conducled in FY 1995 involves:

- Catalytic reforming of model compounds and pyrolysis oils in the continuous flow reformer packed with the different calalysts selected for the study: yields of $\mathrm{H}_{2}$ and time-on-stream data will be obtained.

- Design and construct a fast pyrolysis reactor to integrate with the reformer.

- Technoeconomic reevaluation based on the data obtained.

- Industrial contacts to begin marketing the technology. Markets considered as: (1) $H_{2}$ as transportation fuel; (2) $H_{2}$ for hydrogenation processes: (3) $\mathrm{H}_{2}$ for fuel cells applications. 


\begin{tabular}{|c|c|c|c|c|c|}
\hline $\begin{array}{l}\text { Task } \\
\text { Thtle }\end{array}$ & Municipal Solid Waste to Hydrogen & Contractor & $\begin{array}{l}\text { Lawrence } \\
\text { Livermore National } \\
\text { Laboratory }\end{array}$ & $\begin{array}{l}\text { Principal } \\
\text { Investigator }\end{array}$ & Jeffrey H. Richardson \\
\hline \multicolumn{6}{|c|}{$\begin{array}{l}\text { We also started laboratory test work in support of the MSW preprocess development. This work has shown that hydrothermal treatment of newspaper } \\
\text { produces a concentrated slumy with an acceptable viscosity at a solids content of } 40 \text { wt\% ( } \approx 4500 \text { Btulb). Further optimization of the conditions should make } \\
\text { a } 50 \text { w\% stury possible. We have also started the laboratory work on two real MSW samples, one obtained from pilot plant tests conducted by BioMass inc. } \\
\text { of San Leandro. }\end{array}$} \\
\hline \multicolumn{6}{|c|}{ 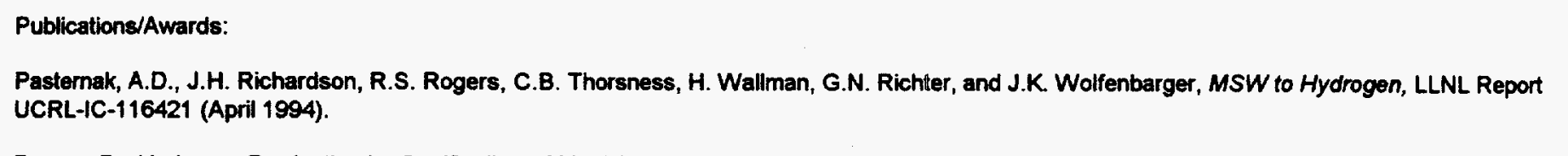 } \\
\hline \multicolumn{6}{|c|}{ Students associated with the Program (Undergraduate, Graduate, Post Doctoral): } \\
\hline \multicolumn{6}{|c|}{$\begin{array}{l}\text { The laboratory work on MSW samples will be carried out to establish favorable hydrothermal processing conditions for real MSW. A study of individual plastic } \\
\text { components will be performed because different plastics respond differently. Some shearing of the samples during the treatment will be attempted in the } \\
\text { laboratory because of the expected benefit of such shearing to the final slurry properties. Further work on slurry rheology is also planned at both LLNL and } \\
\text { Texaco. }\end{array}$} \\
\hline \multicolumn{6}{|c|}{$\begin{array}{l}\text { The main FY95 activity will be modification and operation of a Texaco-built hydrothermal preprocessing pilot plant and experimental testing at LLNL. This } \\
\text { modification is necessary because the batch laboratory work cannot be scaled up without pilot testing. The initial experimental testing will be conducted with } \\
\text { newspaper as feedstock because MSW feedstock requires further additions to the pilot plant. The nominal capacity of the hydrothermal pilot plant will be } 1 \\
\text { torvday (dry weight), but experimental runs will typically be limited to about } 8 \text { hours. The objective is to demonstrate that the high-Btu-content slurry preparation } \\
\text { process based on hydrothermal treatment works with an idealized MSW feedstock. Information for our system study will also be gathered. }\end{array}$} \\
\hline \multicolumn{6}{|c|}{$\begin{array}{l}\text { Gasification pilot plant tests will be started at Montebello with feed slurry prepared from newspaper. Texaco will complete a Phase I economic study of the } \\
\text { overall process, including analysis of the market as well as hydrogen cost. Texaco will also complete a laboratory-scale gasifier that will be able to accept feed } \\
\text { slurry from LLNL in the latter part of FY95 and FY96. }\end{array}$} \\
\hline \multicolumn{6}{|c|}{ In FY96, extension to real MSW feedstock will occur for the preprocessing unit, and the MSW-derived slurries will be used in gasification tests at Montebello. } \\
\hline \multicolumn{6}{|c|}{$\begin{array}{l}\text { The } 1 \text { tor/day hydrothermal pilot plant will be modified additionally to include continuous operation capability. For example, a new dewatering step is needed } \\
\text { for preparing the final high-Btu-content slurry (and for recycling the separated water back to the front end of the plant). Additional augmentation includes } \\
\text { adding a size-rectuction and initial separation step so that real MSW can be fed to the unit. Negotiations are underway with BioMass Inc. to use their pilot plant } \\
\text { as a staring point for this work. This pilot plant reduces the material in particle size and separates the material based on density, all in a water suspension. } \\
\text { The main product consists of a water suspension of the organic, combustible fraction of the MSW which will subsequently be fed to the hydrothermal treatment } \\
\text { unit. Recycling of water to avoid production of excess waste water is an important issue. }\end{array}$} \\
\hline \multicolumn{6}{|c|}{$\begin{array}{l}\text { Samples of the slurries produced at LLNL will be shipped to Texaco's pilot plant in Montebello for gasification tests. The objective is to determine product } \\
\text { yields and properties, particularly the properties of the ash byproduct. Laboratory leaching studies will be performed to assess this product relative to RCRA } \\
\text { and California waste disposal regulations. }\end{array}$} \\
\hline \multicolumn{6}{|c|}{$\begin{array}{l}\text { The FY97 plan calls for integrated MSW-to-hydrogen tests at Montebello. The hydrothermal pretreatment unit, which is built on trailers, will be transported } \\
\text { back lo Montebello for continuous test runs. One objective is to determine product qualities (including ash byproduct) in the face of varying feed quality (MSW } \\
\text { is inherently more variable than other fuel feedstocks). Another objective is to gather data for scaling up the process towards commercial size. }\end{array}$} \\
\hline
\end{tabular}

Technology Development and Validation/Production/Thermochemical 


\begin{tabular}{|c|c|c|c|c|c|c|c|c|}
\hline Task & \multicolumn{4}{|c|}{ Municipal Solid Waste to Hydrogen } & & Lawrence & Principal & Jeffrey H. Richardson \\
\hline \multirow{2}{*}{$\begin{array}{c}\text { Task } \\
\text { Funding } \\
\text { (K\$) }\end{array}$} & FY81 & FY92 & FY93 & FY94 & \multirow{2}{*}{$\begin{array}{c}\text { Hydrogen } \\
\text { Program } \\
\text { Area }\end{array}$} & \multirow{2}{*}{$\begin{array}{l}\text { Production: } \\
\text { Thermochemical }\end{array}$} & \multirow[t]{2}{*}{ Researchers } & \multirow{2}{*}{$\begin{array}{l}\text { Charles B. Thorsness } \\
\text { Henrik Wallman }\end{array}$} \\
\hline & 0 & 0 & 0 & 400 & & & & \\
\hline
\end{tabular}

Objective:

The goal of this project is to develop a commercial process for gasifying municipal solid waste (MSW) to produce hydrogen for use as a premium fuel. A potential use of the hydrogen is in fuel cells. Another important use would be as a feedstock for methanol production, which is a key component for the new gasolinejoxygenate formulations (legislation is pending that requires a fraction of all oxygenates to come from a renewable source, such as MSW).

\section{Approach/Background:}

Our approach is to couple innovative MSW preprocessing technology with established gasification technology. Texaco has developed a high-temperature gasitication process that has been applied commercially throughout the world. However, all applications are fossil fuel-based, and the extension to MSW fueling is difficult. The advantages of high-temperature gasification include a slagged glass-like ash byproduct that is expected to be nonhazardous, even under conditions where the corresponding combustion-derived ash would be classified as hazardous under RCRA. Interestingly, the high-temperature condition required by the slagging process results implicitly in a high yield of hydrogen. Hence hydrogen production and environmentally sound MSW treatment are intimately coupled. An advantage of gasification over MSW combustion is that gasification produces a small-volume fuel gas that is easily cleaned relative to the cleaning of a large-volume flue gas that contains pollutants at low concentrations.

Successfully accomplishing the project goal would lead to reduced landfill disposal, a mandated goal throughout the United States, and to reduced air pollution because hydrogen-fueled power production would displace "dirtier" fossil fuel-based power. Since MSW-fueled power production has the potential of being an "ultra-clean" technology, urban plant locations will be feasible, thus reducing today's transportation-generated air pollution associated with hauling MSW bong distances. A commercial MSW-to-hydrogen process also has strong export potential, particularly to Europe where the pressure to reduce landfill volume is even greater than in the United States.

LLNL and Texaco will cooperatively develop a physical and/or chemical treatment method for preparing and converting MSW to hydrogen by gasification and purification. Initially proposed pretreatments include processing by hydrothermal or dry pyrolysis techniques. Metrics for continual project evaluation range from siurry viscosity and calculated heating values to overall process economics and performance in test runs at the Texaco pilot plant gasifier. This work will analytically evaluate the process to optimize the production of hydrogen, perform bench-scale experiments to measure process variables, and ultimately scale the project for demonstration in the Texaco pilot facility. MSW will initially be modeled using biomass (e.g., cellulose) and subsequently considering other components and related wastes (e.g., sludge, piastics).

The project will consist of six research areas or tasks:

1. A survey of process research on waste and biomass upgrading, slurrying, and liquefaction and of the availability of various potential waste and biomass feedstocks.

2. Determination of the effects of pretreatment on heating value and viscosity properties of slurries. This work will focus on conversion of cellulose and/or general wood polymeric material, recognizing that some plastics will be present.

3. A system analysis of the feed preparation/gasification process to allow process trade-offs to be evaluated on an economic basis.

4. Production of a quantity of feed material for gasification testing and evaluation.

5. Demonstration of MSW and biomass slurrying, characterization of slurrying parameters, and gasification of the MSW and biomass slurries.

6. Development of a measurement/control system to ensure a slagging ash for variable feeds.

Accomplishments/Status:

In our work to establish a sound approach to MSW processing, we had invaluable help from the survey conducted by SRI International under DOE/NREL sponsorship and published in 1982. Our survey of existing technology (Task 1) was thus easily completed.

Task 3 was also completed in terms of its objective of establishing a process approach. This analysis was presented at the DOE contractors' review meeting at Sandia, Livermore in April 1994. A detailed system analysis will continue throughout the project.

Based on the work in Tasks 1 and 3, we concluded that the Texaco gasification process with its requirement for a pumpable feed stream can be adapted to MSW fueling by augmenting the process with a preprocessing step for siurry preparation. As expected, MSW proved in the laboratory tests to be difficult to turn into a pumpable suspension by purely mechanical means with the exception of very dilute conditions. However, our preliminary economic analysis showed that gasification economics is sensitive to the Btu-content of the slurry feed; a dilute feed stream results in poor economics and a very dilute feed cannot be gasified at all. In collaboration with Texaco, we determined that high-pressure hydrothermal preprocessing similar to pulp digestion used in papermaking was an appropriate approach to solve the feed preparation problem. Hydrothermal treatment as applied to waste streams such as sewage sludge has been shown by Texaco and others to produce a high Btu-content slurry. 


\begin{tabular}{|c|c|c|c|c|c|c|c|c|}
\hline $\begin{array}{l}\text { Task } \\
\text { Title }\end{array}$ & \multicolumn{4}{|c|}{$\begin{array}{l}\text { Hydrogen Production from High } \\
\text { Moisture Content Biomass }\end{array}$} & \multirow{3}{*}{$\begin{array}{c}\text { Contractor } \\
\begin{array}{c}\text { Hydrogen } \\
\text { Program } \\
\text { Area }\end{array}\end{array}$} & \multirow{3}{*}{$\begin{array}{l}\text { Hawaii Natural } \\
\text { Energy Institute } \\
\text { University of } \\
\text { Hawaii } \\
\text { Production: } \\
\text { Thermochemical }\end{array}$} & \multirow{3}{*}{$\begin{array}{c}\begin{array}{c}\text { Principal } \\
\text { Investigator }\end{array} \\
\text { Researchers }\end{array}$} & \multirow{3}{*}{$\begin{array}{l}\text { K.R. McKinley } \\
\text { R.E. Rocheleau } \\
\text { M. Antal, Jr. (Task Leader) } \\
\text { Xiadong Xu } \\
\text { Yukihiko Matsumura } \\
\text { Jonny Stenberg } \\
\text { Peter Lipnik }\end{array}$} \\
\hline \multirow{2}{*}{$\begin{array}{l}\text { Task } \\
\text { Funding } \\
\text { (K\$) }\end{array}$} & FY91 & FY92 & FY93 & FY94 & & & & \\
\hline & $* *$ & 14 & 10 & 52 & & & & \\
\hline \multicolumn{9}{|c|}{$\begin{array}{l}\text { Objective: } \\
\text { To identify reaction conditions and catalysts that improve the efficiency of hydrogen production from gasification of high-moisture content biomass in } \\
\text { supercritical water. }\end{array}$} \\
\hline \multicolumn{9}{|c|}{$\begin{array}{l}\text { Gucose was selected as a model compound for catalytic biomass gasification. Water hyacinth, paper sludge, and depithed bagasse liquid extract were studied } \\
\text { as representative wet biomass feedstocks. A proprietary heterogeneous catalyst } X \text { was extremely effective for the gasification of both the model compound } \\
\text { and whole biomass feeds. }\end{array}$} \\
\hline \multicolumn{9}{|c|}{$\begin{array}{l}\text { As high as } 22 \% \text { (by weight in water) glucose can be completely gasified to a hydrogen rich gas with catalyst } X \text { at a WHSV as high as } 22.2 \text { (g/hr)/g in } \\
\text { supercritical water at } 600^{\circ} \mathrm{C}, 34.5 \mathrm{MPa} \text {. Complete conversions of low concentrations of whole biomass feeds including water hyacinth, depithed bagasse } \\
\text { liquid extract, and paper sludge have also been achieved. }\end{array}$} \\
\hline $\begin{array}{l}\text { Publicatio } \\
\text { A patent }\end{array}$ & $\begin{array}{l}\text { Awards } \\
\text { lication }\end{array}$ & e prop & \multicolumn{6}{|c|}{ A patent application on the proprietary catalyst $X$ is being filed by the University of Hawaii. } \\
\hline \multicolumn{9}{|c|}{$\begin{array}{l}\text { Undergraduate: Anita Hansen } \\
\text { Graduate: Peter Lipnik } \\
\text { Post-Doctoral Fellow: Dr. Yukihiko Matsumura }\end{array}$} \\
\hline \multicolumn{9}{|c|}{ Future Directions/Industry Interactions: } \\
\hline
\end{tabular}

** Allocations for FY 91 included \$74K for Program Management. 


\begin{tabular}{|c|c|c|c|c|c|c|c|c|}
\hline $\begin{array}{l}\text { Task } \\
\text { Title }\end{array}$ & \multicolumn{4}{|c|}{$\begin{array}{l}\text { Synthesis, Characterization, and } \\
\text { Modeling of Carbon Aerogels for } \\
\text { Hydrogen }\end{array}$} & Contractor & $\begin{array}{l}\text { Lawrence } \\
\text { Livermore National } \\
\text { Laboratory }\end{array}$ & $\begin{array}{c}\text { Principal } \\
\text { Investigator }\end{array}$ & R.W. Pekala \\
\hline \multirow{2}{*}{$\begin{array}{l}\text { Task } \\
\text { Funding } \\
\text { (K\$) }\end{array}$} & FY91 & FY92 & FYg3 & FY94 & \multirow{2}{*}{$\begin{array}{c}\text { Hydrogen } \\
\text { Program } \\
\text { Area }\end{array}$} & \multirow[t]{2}{*}{ Storage } & \multirow[t]{2}{*}{ Researchers } & \multirow[t]{2}{*}{ C.T. Alviso } \\
\hline & 0 & 0 & 0 & 100 & & & & \\
\hline
\end{tabular}

Objective:

The objective of this work is to synthesize, characterize, and model carbon aerogels as a medium for hydrogen storage. This work is part of LLNL's systems approach to developing the critical technologies necessary to support the introduction of hydrogen or hydrogen-natural gas mixtures as transportation fuels, which would provide a sustainable, environmentally benign alternative to the use of imported petroleum.

\section{Approach/Background:}

Hydrogen can be adsorbed at high densities on the surface of activated, cryogenic carbons. The overall density of the hydrogen in the carbon/hydrogen system increases as the adsorbing surface area per unit volume increases. Conventional superactivated carbons have high surface-to-mass ratios but their typically low density results in a low surface area per unit volume. Carbon aerogels, however, permit the independent control of density and surface-to-mass ratio. Hence, the surface-fo-volume ratio may be optimized for hydrogen storage. Al LLNL, low-density carbon aerogels have already exhibited hydrogen densities that correspond to values greater than $30 \mathrm{~kg} \mathrm{H} / \mathrm{m}^{3}$ at $80 \mathrm{~K}$ and $3600 \mathrm{psi}$. There are early indications that the organic precursor to the carbonized aerogel may be able to adsorb more hydrogen per unit than the final carbon aerogel. This is probably a result of the extremely high surface areas achievable in organic aerogels.

Using the current carbon aerogel as a point of departure, we will optimize the density for organic and carbon aerogels exhibiting the highest surface-to-mass ratio. The adsorption loading and kinetics will be measured as a function of temperature. The mass and heat transfer rates will be measured as a function of aerogel density, so that a system with reasonable charging and cooling/heating rates can be designed. These measurements will be used to update the current aerogel hydrogen storage model. To optimize container fill, aerogel samples will be fabricated in micropellet form. An engineering prototype carbon aerogel storage system will be built to study the real charge, discharge, handling and capacity characteristics. It will be pressurized to 3600 psi to utilize the void space within the aerogel as an enhancement to the adsorbed hydrogen storage. We will also generate a computer model employing molecular dynamics to help predict the hydrogen storage performance of aerogels.

\section{Accomplishments/Status:}

Continued development of inverse emulsion process for the production of organic aerogel micropellets and their carbonized derivatives demonstrated that $>50 \mathrm{~g}$ batches of material can be synthesized using this process.

Produced $150 \mathrm{cc}$ of carbon aerogel micropellets for evaluation in a prototype pressure vessel at A.D. Little.

Examined particle size distribution and studied hydrogen adsorption properties of carbon aerogel micropellets.

Compared the hydrogen adsorption properties of carbon aerogels that have been supercritically dried vs. air dried.

Developed method for the chemical activation of aerogel micropellets, leading to increased surface area and improved hydrogen storage.

Initiated a computer modeling effort using molecular dynamics simulation to generate amorphous carbon networks.

Publications/Awards:

None

Students associated with the Program (Undergraduate, Graduate, Post Doctoral):

None

Future Directions/Industry Interactions:

FY95 Efforts

Begin computer modeling of hydrogen adsorption at carbon surfaces as a function of micropore diameter and surface group distribution.

Examine the chemical derivation of resorcinol-formaldehyde (RF) and melamine-formaldehyde (MF) aerogels as a method for improving hydrogen storage.

Evaluate the effects of chemical doping (e.g., P) on carbon structure and subsequent hydrogen storage.

Demonstration that carbon aerogels can be doped with metals that have a high affinity for hydrogen adsorption. 


\begin{tabular}{|c|c|c|c|c|c|}
\hline $\begin{array}{l}\text { Task } \\
\text { Titte }\end{array}$ & $\begin{array}{l}\text { Synthesis, Characterization, and } \\
\text { Modeling of Carbon Aerogels for } \\
\text { Hydrogen }\end{array}$ & Contractor & $\begin{array}{l}\text { Lawrence } \\
\text { Livermore National } \\
\text { Laboratory }\end{array}$ & $\begin{array}{l}\text { Principal } \\
\text { Investigator }\end{array}$ & R.W. Pekala \\
\hline \multicolumn{6}{|c|}{$\begin{array}{l}\text { Select optimum carbon aerogel formulation and measure hydrogen adsorption properties over complete temperature range }(77-273 \mathrm{~K}) \text { and pressure } \\
(0-3600 \mathrm{psi}) \text {. In effect this will yield the phase diagram for hydrogen on this aerogel. }\end{array}$} \\
\hline \multicolumn{6}{|c|}{$\begin{array}{l}\text { Select optimum RF and MF aerogel formulation and measure hydrogen adsorption properties over complete temperature range }(77-273 \mathrm{~K}) \text { and pressure } \\
(0-3600 \mathrm{psi}) \text {. In effect this will yield the phase diagram for hydrogen on this aerogel. }\end{array}$} \\
\hline \multicolumn{6}{|c|}{ FY96 Efforts } \\
\hline \multicolumn{6}{|c|}{ Demonstrate the production of a $200 \mathrm{~g}$ batch of carbon aerogel micropellets using an inverse emulsion process. } \\
\hline
\end{tabular}




\begin{tabular}{|c|c|c|c|c|c|c|c|c|}
\hline $\begin{array}{l}\text { Task } \\
\text { Title }\end{array}$ & \multicolumn{4}{|c|}{$\begin{array}{l}\text { Hydrogen Storage in Engineered } \\
\text { Microspheres }\end{array}$} & Contractor & $\begin{array}{l}\text { Lawrence } \\
\text { Livermore National }\end{array}$ & $\begin{array}{c}\text { Principal } \\
\text { Investigator }\end{array}$ & Glenn Rambach \\
\hline \multirow{2}{*}{$\begin{array}{l}\text { Task } \\
\text { Funding } \\
\text { (KS) }\end{array}$} & Fro1 & FY92 & FY93 & Frgs & \multirow{2}{*}{$\begin{array}{c}\text { Hydrogen } \\
\text { Program } \\
\text { Area }\end{array}$} & \multirow[t]{2}{*}{ Storage } & \multirow[t]{2}{*}{ Researchers } & \\
\hline & 0 & 0 & 0 & 50 & & & & \\
\hline
\end{tabular}

Objective:

The objective is to develop a novel storage method that will permit the safe, effective, and economical bulk storage and transport of hydrogen. New, highstrength glass microspheres filled with pressurized hydrogen exhibit densities that make them attractive for such bulk hydrogen storage and transport.

Approach/Background:

Commercially produced glass microspheres were studied in the late 1970s for their application to storage of hydrogen. These spheres have diameters of 25 to $500 \mu \mathrm{m}$ and wall thicknesses of approximately $1 \mu \mathrm{m}$. At elevated temperatures of $200-400^{\circ} \mathrm{C}$, the reduced permeability of the glass permits them to be pressurized with hydrogen. Fil rates are a function of glass properties, permeating gas, and temperature and pressure differentials. The commercial spheres were usually made by spraying glass frits or gels into a furnace. Because of defects in the sphere membrane, the hoop stress at failure of the commercial microspheres was limited to about 50,000 psi. Because LLNL's Laser Fusion Program needed glass microspheres made under much more controlled conditions, a method of microsphere production was developed that resulted in defect-free microspheres with ultimate hoop stress of about 150,000 psi, permitting a three-fold increase in pressure limits for microsphere of the same dimensions and materials as the commercial ones.

Accomplishments/Status:

A bed of 50- $\mu$ m-diameter engineered microspheres with 1.1- $\mu \mathrm{m}$-thick membranes and 150,000 psi hoop stress at burst, containing hydrogen at 9000 psi at a 1.5 safety factor, could exhibit a hydrogen mass fraction of $10 \%$ and a hydrogen bed density of $20 \mathrm{kgH}_{2} / \mathrm{m}^{3}$. Analysis of several infrastructures, production, end-use, and market scenarios indicate that hydrogen rail transportation in glass microspheres can be competitive with liquid hydrogen.

Publications/Awards:

None

Students associated with the Program (Undergraduate, Graduate, Post Doctoral):

None

Future Directions/Industry Interactions:

In 1995 we will complete a CRADA with Praxair and W.J. Schafer Associates (WJSA) focused on the production of sufficient quantities of glass microspheres to evaluate the critical intrinsic bed properties that are relevant to near-term commercialization. They will be manufactured by the process developed at LLNL, which results in defect-free microspheres. A glass microspheres production facility will be assembled at WJSA to produce $\mathrm{cm}^{3}$-quantities of microspheres for evaluation. Small beds of current-technology glass microspheres will be produced at WJSA. A microsphere hydrogen storage evaluation test facility will be assembled at LLNL within the high-pressure facilty. This will be capable of loading and unloading small beds of spheres at temperatures up to $400^{\circ} \mathrm{C}$ and pressures up to 10,000 psi.

Several small microsphere beds, spanning a range of concentration of network modifiers, will be evaluated for their actual hydrogen storage mass fraction and volumetric density. The loading and unloading kinetics will also be measured, and the measurements will be used to validate and enhance the density and kinetic model developed for microsphere hydrogen storage beds.

To identify development pathways for improving on the storage density and charge/discharge kinetics, we will perform a literature study to identify all material candidates that may satisfy the properties necessary in microspheres for high mass fraction storage of hydrogen and that potentially offer increased permeability control compared to current glass microspheres.

We will design the microsphere PVT test cell which will be used to supply the controlled pressure, volume and temperature environment necessary to accurately measure the loading characteristics and behavior $\mathrm{cm}^{3}$-quantities of the microspheres as they are developed. Heating will be accomplished with resistive heating elements. The system will also have the capability of containing the microsphere samples in a container of low heat capacity and conductivity. This apparatus will perform the equivalent function of a Sieverts apparatus used in the evaluation of metal hydrides for hydrogen storage. A piezoelectric pickup will be included to measure the pressure burst and crush statistic of the microspheres. Fabrication will begin in FY95. 


\begin{tabular}{|c|c|c|c|c|c|c|c|c|}
\hline Task & \multicolumn{4}{|c|}{ Novel Materials for Hydrogen Storage } & Contractor & NREL & Principa! & Michael J. Heben \\
\hline \multirow{2}{*}{$\begin{array}{c}\text { Task } \\
\text { Funding } \\
\text { (K\$) }\end{array}$} & FY91 & Fr92 & FY93 & FYs4 & \multirow{2}{*}{$\begin{array}{c}\text { Hydrogen } \\
\text { Program } \\
\text { Area }\end{array}$} & \multirow[t]{2}{*}{ Storage } & \multirow[t]{2}{*}{ Researchers } & \multirow{2}{*}{$\begin{array}{l}\text { Tim A. Bekkedah } \\
\text { Andrew F. Cahill } \\
\text { Anne C. Dillon }\end{array}$} \\
\hline & 0 & 0 & 190 & 255 & & & & \\
\hline
\end{tabular}

Objective:

Imvestigate new solid-state hydrogen storage options possessing the potential for quantum jump improvements over currently available technologies. Current focus is on hydrogen adsorption in the recently discovered family of materials known as carbon nanotubes. A key goal is the synthesis of assemblies of identical carbon nanotubes. Such assemblies are expected to be superior hydrogen adsorbents, and will allow definition of the ultimate performance of graphitic porous carbons in hydrogen storage applications.

\section{Approach/Background:}

Carbon nanostructural units that can be organized and assembled into optimal configurations for hydrogen storage by adsorption have been an initial focus of our work. This research direction is founded on the realization that; i) high-surface-area carbon materials have the potential to meet both the volumetric and gravimetric DOE energy density targets for transportation if concurrent increases in hydrogen storage capacity and carbon density can be achieved, ii) such increases are unlikely to be achieved with conventional porous materials in which surface area and material density are generally inversely related, and iii) the adsorption storage capability of a material will be maximized when both the surface area and the nanopore volume fraction are maximized if the strength of the hydrogenvcarbon interaction remains at least constant with changes in porosity and density. This latter situation is obtained in a high-surface-area material with minimal macropore volume. Indeed, if materials can be synthesized with nanoporous volumes of the proper dimensions such that nanocapillary filling mechanisms are activated, then hydrogen storage could be achieved at higher temperatures and lower pressures than is found for conventional cryoadsorbents. This type of structural arrangement can be realized with the use of engineered carbon nanotubules.

\section{Accomplishments/Status:}

We have performed two closely coupled tasks to assess the viability of using engineered carbon nanotubes for hydrogen storage applications. The first task utilizes a customized microbalance to investigate hydrogen uptake in nanotubule-containing samples under a variety of temperature and pressure conditions. To date, we have measured gravimetric hydrogen storage densities ranging from 5 to $8 w t \%$ at $82 \mathrm{~K}$ and 14 psi of hydrogen. These early results compare very favorably with the best activated carbons which display similar storage densities at much higher pressures (800 psi).

The second task is focused on the synthesis of carbon nanotubes and nanotubule assemblies. Activity in this area has involved construction of an arcdischarge apparatus which provides fine control over synthesis parameters to enable basic studies of the nucleation and growth of carbon nanotubes. Knowiedge of the undertying chemistry and physics of nanotube formation will provide guidance for the large-scale synthesis of optimal carbon nanotubes, which is also a goal of our work. Towards this goal, we have recently succeeded in the synthesis of $12 \mathrm{~A}$ single-walled carbon nanotubes by co-evaporation of cobalt and carbon in the arc-discharge apparatus. Transmission electron microscopy and scanning tunneling microscopy techniques have also been developed to provide structural analysis of the synthesized materials.

Publications/Awards:

Bekkedahi, T.A.; Heben, M.J.(1994). "Advanced Materials for Hydrogen Storage: Carbon Nanotubules" Proceedings of the 1994 DOE/NREL Hydrogen Program Review; April 18-20, 1994, Livermore, CA

M.J. Heben, "Hydrogen Storage Options for Vehicles", Presentation at The Joint Center for Fuel Cell Vehicles, Colorado School of Mines, Golden, CO, June 2, 1994.

M.J. Heben was selected to participate in the workshop entitled "Basic Research Needs for Vehicles of the Future". The Workshop is jointly sponsored by NSF and DOE in partnership with Chnsler, Ford Motor Company, and General Motors, and seeks to develop input for the recently-formed Partnership for the New Generation Vehicle.

Students associated with the Program (Undergraduate, Graduate, Post Doctoral):

Timothy A. Bekkedahl, Undergraduate Student, Physics, Colorado School of Mines, Golden, Co

Andrew F. Cahill, Undergraduate Student, Electrical Engineering, Denver University, Denver, co.

Anne C. Dillon, Postdoctoral Research Associate.

Future Directions/Industry Interactions:

Future work will include measurement of hydrogen capacity and heat of adsorption on separated and purified materials (nanotubes, cobalt nanoparticles, amorphous carbon) produced by co-evaporation of $\mathrm{Co}$ and $\mathrm{C}$ in arc-discharge apparatus. We will also focus on developing methods for the low-cost production of bulk quantities of carbon nanotubes.

Our collaborations with D.S. Bethune at IBM, and J.K. Johnson and J.Q. Broughten at Naval Research Labs, will continue. Recent interactions with TDA Research, Inc. (Wheat Ridge, CO), and MER Corporation (Tucson, AZ) will also continue with the goal of establishing a CRADA, if appropriate. 


\begin{tabular}{|c|c|c|c|c|c|c|c|c|}
\hline $\begin{array}{l}\text { Task } \\
\text { Title }\end{array}$ & \multicolumn{4}{|c|}{ Hydride Development } & Contractor & Sandia National & $\begin{array}{c}\text { Principal } \\
\text {. }\end{array}$ & George J. Thomas \\
\hline \multirow{2}{*}{$\begin{array}{c}\text { Task } \\
\text { Funding } \\
\text { (K\$) }\end{array}$} & FY81 & FY92 & FYo3 & Fre4 & \multirow{2}{*}{$\begin{array}{c}\text { Hydrogen } \\
\text { Program } \\
\text { Area }\end{array}$} & \multirow[t]{2}{*}{ Storage } & \multirow[t]{2}{*}{ Researchers } & \multirow{2}{*}{$\begin{array}{l}\text { S.E. Guthrie } \\
\text { N.Y.C. Yang }\end{array}$} \\
\hline & 0 & 0 & 0 & 200 & & & & \\
\hline
\end{tabular}

Objective:

The task objective is to investigate and improve on the hydrogen storage properties of lightweight hydrides. This task is integrated with a storage system engineering task and will supply materials for an engineering demonstration.

Approach/Background:

Hydrides offer some attractive advantages over high pressure or cryogenic systems: they have very high volumetric density, they are relatively safe, they do not require active cooling or monitoring and they have been demonstrated onboard vehicles. A major disadvantage of hydrides, particularly for transportation applications, is their retatively low weight density. Other factors, such as the relationship between equilibrium pressure and temperature (van't Hoff equation) and kinetic properties, for example, also define the operating envelope of a hydride and must be considered in specific applications.

Hydride technology is a relatively mature field of study and the literature on this subject is extensive. In particular, there have been a number of studies aimed at modifying the behavior of magnesium, a candidate for lightweight hydrogen storage, either by surface treatments or by alloy additions. These previous studies, however, mostly utilized temperature regimes where significant microstructural changes were occurring during measurements and these effects were not considered. Our approach in studying $\mathrm{Mg}$-based hydrides is to (a) enhance kinetic properties by surface modifications to allow low temperature measurements $\left(<300^{\circ} \mathrm{C}\right)$, (b) systematically explore alloy additions to reduce the hydride dissociation enthalpy, and (c) perform microstructural analyses on materials before and after hydride cycling to determine phase structure and stability. Initially, Ni and Al additions will be studied, with equilibrium pressurecomposition-temperature measurements, kinetic release measurements and electron microprobe analysis being the major experimental techniques.

Accomplishments/Status:

- A low temperature $\left(300^{\circ} \mathrm{C}\right)$ data base of overpressure and kinetic properties has been established for Mg based hydrides. This was accomplished by using a simple mechanical alloying technique for enhancing the release kinetics. These measurements have yielded information at lower temperatures than has been previously reported in the literature.

-

A new synthesis approach has been found for fabricating $\mathrm{Mg}_{2} \mathrm{Ni}$ hydride material with controlled particle size. This technique can produce small particle size material with a narrow size range and excellent kinetic properties. The small size appears to mitigate attrition problems, that is, break-up of hydride particles, caused by repeated hydride cycling.

- Kinetic and pressure-composition-temperature (PCT) data were provided for an engineering bed design based on $\mathrm{Mg}_{2} \mathrm{Ni}$ hydride.

- Extensive measurements have been performed on a MgAINi alloy which exhibits very promising results. This alloy had excellent kinetic properties at temperatures as low as $150^{\circ} \mathrm{C}$, and a relatively high overpressure at $200^{\circ} \mathrm{C}$. These hydride properties offer the potential for lower temperature operation than any other $\mathrm{Mg}$ alloy. The alloy was formed in situ and consequently has a complex microstructure. Detailed microstructural analyses have been performed and these results compared with other results to identify the active hydride phases.

We have developed a correlation between microstructure and physical behavior in $\mathrm{Mg}-\mathrm{Ni}$ and $\mathrm{Mg}$-Al hydrides which will be used to define the metallurgical requirements in our ongoing $\mathrm{Mg}$ alloy development. Based on our work to date, a list of ailoys, mainly in the Mg-Al-Ni system, was developed and fabrication of these materials has begun. Two different metallurgical processes are being used to generate the alloys - bulk casting by an industrial supplier and rapidly solidified powder metallurgy at UC Irvine.

Publications/Awards:

G. J. Thomas, B. A. Meyer, S. E. Guthrie, and D.F. Cowgill (1994) "Hydrogen Storage: Advanced Materials Development and Integrated System Design." Proceedings of the DOENREL Hydrogen Program Review; April 1994, Livermore, CA.

Students associated with the Program (Undergraduate, Graduate, Post Doctoral):

None 


\begin{tabular}{|c|c|c|c|c|c|}
\hline $\begin{array}{l}\text { Task } \\
\text { Title }\end{array}$ & Hydride Development & Contractor & $\begin{array}{l}\text { Sandia National } \\
\text { Laboratories }\end{array}$ & $\begin{array}{c}\text { Principal } \\
\text { Investigator }\end{array}$ & George J. Thomas \\
\hline
\end{tabular}

Future Directions/Industry Interactions:

- Extend the work on the MgAINi alloy to develop a metallurgical process which can consistently synthesize material with the required physical properties. Determination of the hydrogen storage weight fraction of this alloy will be made.

- When the above tasks are completed, a metallurgical process will be defined to fabricale a larger quantity of this alloy. An industrial or university partner will then be identified for generating sufficient material for building lab scale and prototype hydride beds.

- A quantity of small particle size $\mathrm{Mg}_{2} \mathrm{Ni}$ will be synthesized using the technique previously developed. This material will be characterized and supplied for incorporation into a lab scale bed. The behavior of the hydride bed containing this material will be compared to that obtained from a conventional $\mathrm{Mg}_{2} \mathrm{Ni}$ material.

- In an effort to make further improvements in the weight-temperature-pressure properties of hydrides, PCT and kinetic measurements will be made on the series of cast and powder alloys which were defined previously. These results will again be correlated with microstructural analyses in order to help define promising new alloys as well as to indicate expected evolutionary changes in the alloys with high temperature exposure. 


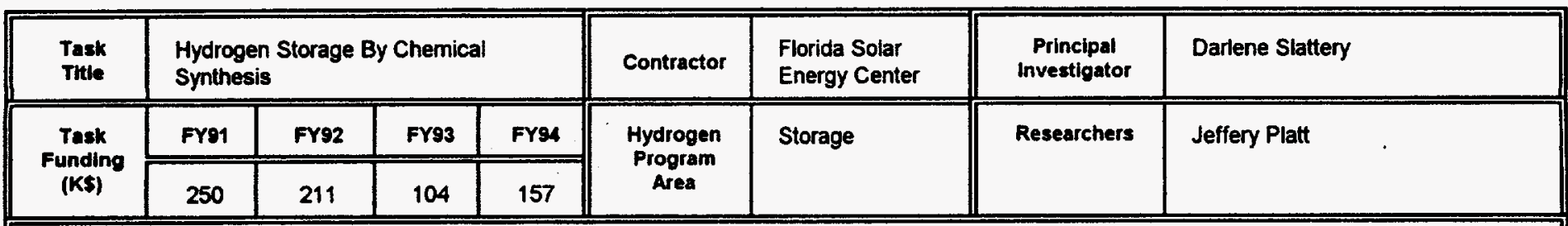

Objective:

To develop a magnesium-based hydride which contains $6 w \%$ hydrogen but which dehydrogenates at around $200^{\circ} \mathrm{C}$.

\section{Approach/Background:}

It is now well established that the use of the chemical approach to preparing magnesium hydride allows the preparation under mild conditions although magnesium has long been considered very difficult to hydride. By applying the same procedure to the synthesis of alloys, it should be possible to form hydrides from materials not previously known to react directiy with hydrogen.

Accomplishments/Status:

Aloys of magnesium-iron-aluminum and magnesium-iron-nickel were found to hydride easily using the chemical approach. The dehydrogenation temperature for these alloys is $30-50^{\circ} \mathrm{C}$ lower than is required for the unalloyed magnesium. A detailed study of $\mathrm{La}_{2} \mathrm{Mg}_{17}$ indicated that there are lower energy level sites accessible to the hydrogen when hydrogenation is carried out at lower temperatures. The result is that the dehydrogenation temperature can be varied by more than $60^{\circ} \mathrm{C}$ by varying the conditions for uptake.

Publications/Awards:

Skattery. D.K (1994). "Chemically Synthesized Hydrogen Storage Compounds." Proceedings of the 1994 DOE/NREL Hydrogen Program Review; April 1994 Livermore. California.

Stattery, D.K. (1994) "Hydrogen Storage Technologies." Presented at a Workshop on Hydrogen Storage, Battelle Institute, Columbus, Ohio, September 13, 1994.

Slattery, D. K. "A Study of the Dehydrogenation Behavior of $\mathrm{La}_{2} \mathrm{Mg}_{17}$ ". Submitted for publication in Int. J. Hydrogen Energy.

Students associated with the Program (Undergraduate, Graduate, Post Doctoral):

Janice Lomness, James Guidry

Future Directions/Industry Interactions:

Although the work is not currently funded, we are continuing to pursue additional support. We have established a collaboration with the Naval Research Laboratory in Washington, D.C. and are analyzing samples of their hydrides in exchange for alloys prepared to our specifications. Additional work needs to be done on the $\mathrm{La}_{2} \mathrm{Mg}_{1}$ system in order to fully understand the results of the investigation. We believe that much can be learned from this system about the hydrogenation - dehydrogenation process in metals. 


\begin{tabular}{|c|c|c|c|c|c|c|c|c|}
\hline $\begin{array}{l}\text { Task } \\
\text { Title }\end{array}$ & \multicolumn{4}{|c|}{$\begin{array}{l}\text { Nonclassical Polyhydrides Metal } \\
\text { Complexes for } \mathrm{H}_{2} \text { Storage }\end{array}$} & Contractor & $\begin{array}{l}\text { Hawaii Natural } \\
\text { Energy Institute }\end{array}$ & $\begin{array}{l}\text { Principal } \\
\text { Investigator }\end{array}$ & $\begin{array}{l}\text { K.R. McKiniey } \\
\text { R.E. Rocheleau }\end{array}$ \\
\hline \multirow[t]{2}{*}{$\begin{array}{l}\text { Task } \\
\text { Fundlng } \\
\text { (K\$) }\end{array}$} & FY91 & Fr92 & FY93 & FY94 & \multirow[t]{2}{*}{$\begin{array}{l}\text { Hydrogen } \\
\text { Program } \\
\text { Area }\end{array}$} & Storage & \multirow[t]{2}{*}{ Researchers } & \multirow{2}{*}{$\begin{array}{l}\text { C.M. Jensen(Task Leader) } \\
\text { Dr. Trang Le-Husebo } \\
\text { Dr. Quiongzhong Jiang } \\
\text { Jack Belli } \\
\text { Mukta Gupta } \\
\text { Melissa Kido }\end{array}$} \\
\hline & 45 & 66 & 56 & $140^{*}$ & & & & \\
\hline
\end{tabular}

Objective:

Synthesis of novel nonctassical polythydride complexes which reversibly bind hydrogen under mild conditions and contain a high weight percentage of available hydrogen.

Approach/Background:

Nonclassical metal hydride complexes contain hydrogen which binds to the metal center while retaining a significant amount of $\mathrm{H}-\mathrm{H}$ bonding. As a result, these complexes reversibly bind $\mathrm{H}_{2}$ under mild conditions. We have synthesized and characterized nonclassical polyhydride complexes of the formula I $\mathrm{H}_{2} \mathrm{X}\left(\mathrm{H}_{2}\right)(\mathrm{PPr})_{2}(\mathrm{X}=\mathrm{CL}, \mathrm{Br}, \mathrm{I})$. An understanding of how the energetics of hydrogen binding can be fine tuned by small changes in the ligand environment is emerging through our continuing studies of the reversible loss of $\mathrm{H} 2$ from these complexes. In an attempt to produce materials which contain a high weight percentage of available hydrogen, we have explored the synthesis of monocobalt complexes that are stabilized by cyclopentadienyl ligands.

Accomplishments/Status:

We have demonstrated through variable temperature $1_{H}$ NMR spectroscopy that the energetics of the reversible loss of hydrogen from non-classical polyhydrides can be fine tuned by the sterics and electronics of the ligand environment. During FY94, the energetics of this process were more reliably determined through variable temperature ${ }^{31} \mathrm{P}$ NMR spectroscopy. The hydrogen binding process has also been studied through infrared spectroscopy and (in collaboration with Dr. Juergen Eckert of Los Alamos National Laboratory) by inelastic neutron scattering. We have also determined the molecular structure, including the metal bound mydrogens, of $\mathrm{IrH}_{2} \mathrm{l}\left(\mathrm{H}_{2}\right)(\mathrm{PPr} 3)_{2}$ through a single crystal neutron diffraction study with Dr. Thomas Koetzle of Brookhaven National Laboratory.

Publications/Awards:

Juergen Eckert, Craig M. Jensen, Ginger Jones, Eric Clot, Odile Einstein, "An Extremely Low Barrier to Rotation of Dihydrogen in the Complex $\left.\mathrm{IrH}_{2} \mathrm{CL}\left(\mathrm{H}_{2}\right)(\mathrm{PPr})_{3}\right)_{2}$." Journal of the American Chemical Society $1993,115,11056$.

Trang Le-Husebo and Craig M. Jensen, "Influence of Halide Ligands on the Energetics of the Reversible Loss of Hydrogen from the Iridium Nonclassical Polyhydride Complexes: $\mathrm{Ir}_{2} \mathrm{X}\left(\mathrm{H}_{2}\right)\left(\mathrm{PPr}^{\mathrm{i}}\right)_{2}(\mathrm{X}=\mathrm{C1}, \mathrm{Br}, \mathrm{I})^{n}$. Inorganic Chemistry 1993, 32, 3797.

Juergen Eckert, Craig M. Jensen, Thomas F. Koetzle, Trang Le-Husebo, Jacqueline Nicol, Ping Wu, "Inelastic Neutron Scattering Studies of the Influence of Ancillary Ligands on Metal-Dihydrogen PI bonding. "Determination of Molecular Structure of $I \mathrm{rH}_{2} \mathrm{I}\left(\mathrm{H}_{2}\right)(\mathrm{PPr} 3)_{2}$ by Neutron Diffraction. Submitted to Journal of the American Chemical Society.

Students associated with the Program (Undergraduate, Graduate, Post Doctoral):

Dr. Trang Le-Husebo (post-doctoral fellow)

Dr. Quiongzong Jiang (post-doctoral fellow)

Jack Belli (grad student)

Mukta Gupta (grad student)

Melissa Kido (undergrad)

Future Directions/industry Interactions:

Exploration of the possibility that idenyl complexes will store hydrogen through reversible hydrogenation of the idenyl ligand as well as the metal center

* FY 94 includes $\$ 44 \mathrm{~K}$ modification for engineering characterization of novel polyhydride complexes. 


\begin{tabular}{|c|c|c|c|c|c|c|c|c|}
\hline Task & \multicolumn{4}{|c|}{ Storage System Engineering } & Contractor & Sandia National & Principal & James L. Hancock \\
\hline \multirow{2}{*}{$\begin{array}{l}\text { Task } \\
\text { Funding } \\
\text { (K\$) }\end{array}$} & FY91 & FY92 & FY93 & FYsA & \multirow{2}{*}{$\begin{array}{l}\text { Hydrogen } \\
\text { Program } \\
\text { Area }\end{array}$} & \multirow[t]{2}{*}{ Storage } & \multirow[t]{2}{*}{ Researchers } & \multirow{2}{*}{$\begin{array}{l}\text { J.L. Hancock } \\
\text { K. Wally }\end{array}$} \\
\hline & 0 & 0 & 0 & 200 & & & & \\
\hline
\end{tabular}

Objective:

Design, fabricate and demonstrate a hydrogen storage system utilizing a lightweight hydride and integrate the system with an oplimized internal combustion engine.

\section{Approach/Background:}

Previous engineering demonstrations of hydride storage beds aimed at vehicular applications have utilized low temperature, but heavy, hydride materials. This weight affects vehicle range and performance, and is a major obstacle to hydrogen use in transportation. Lighter weight magnesium-based alloys offer significant weight savings, but the higher temperature and energy requirements have prevented their consideration in engineering studies. Our work will be directed toward the development of hydride storage systems, based on lightweight hydrides, which consider high temperature operation, efficient and effective heat transfer, efficient bed packing design, and mechanical stability. The materials work on hydride development and containment materials will be closely coupled with these engineering activities, and, from a systems point of view, the storage module performance matched to the engine requirements developed in the hydrogen engine project. This work will be directed towards the goal of hardware demonstrations by the end of FY97.

Accomplishments/Status:

An experimental hydride bed was fabricated which allowed thermal conductivity measurements to be made. The bed consisted of LaNi hydride packed to a density of $50 \%$. It was found that the overpressure gas was the dominant contributor to thermal conductivity except at low pressures. For hydrogen, the conductivity increased rapidly with pressure and saturated to a value $7-8$ times the particle contribution at about 350 psi. Gas flow (permeability) measurements were also performed and reported.

Hardware for a prototype hydride bed using $\mathrm{Mg}_{2} \mathrm{Ni}$ has been fabricated. A long, cylindrical geometry was employed. The intent of this bed is to test high temperature behavior and to measure wall loading resulting from hydride cycling.

Publications/Awards:

G. J. Thomas, B. A. Meyer, S. E. Guthrie, and D.F. Cowgill (1994) "Hydrogen Storage: Advanced Materials Development and Integrated System Design." Proceedings of the DOENREL Hydrogen Program Review; April 1994, Livermore, CA.

Students associated with the Program (Undergraduate, Graduate, Post Doctoral):

None

Future Directions/Industry Interactions:

Future work will be closely coupled to the hydride development and engine tasks. The engineering process will consider overall system requirements in order to optimize the storage system and match hydride requirements (e.g., temperature, energy) with engine requirements (e.g., gas delivery rate, pressure). Furthermore, material development of new alloys (and their fabrication methods) will be fully integrated into the engineering design process. Specific near-term objectives are:

- A study will be initiated to define engineering design objectives for achieving a significant demonstration by the end of FY97, and the process for reaching that goal will be identified. This study will be completed in a 3-4 month time frame.

A prototype hydride bed with $\mathrm{Mg}_{2} \mathrm{Ni}$ will be completed and measurements begun. A manifold to simulate engine requirements will be made and used in these measurements. These will be the first engineering tests aimed at determining the feasibility of high temperature hydride bed operation for supplying hydrogen to an engine. 


\begin{tabular}{|c|c|c|c|c|c|c|c|c|}
\hline $\begin{array}{l}\text { Task } \\
\text { Thtle }\end{array}$ & \multicolumn{4}{|c|}{$\begin{array}{l}\text { Systems Study of Metal Hydride } \\
\text { Storage Requirements }\end{array}$} & Contractor & $\begin{array}{l}\text { Florida Solar } \\
\text { Research Center }\end{array}$ & $\begin{array}{l}\text { Princlpal } \\
\text { Investigator }\end{array}$ & Ali T-Raissi \\
\hline \multirow{2}{*}{$\begin{array}{l}\text { Task } \\
\text { Funding } \\
\text { (KS) }\end{array}$} & FYO1 & FY92 & FY83 & FYs4 & \multirow{2}{*}{$\begin{array}{c}\text { Hydrogen } \\
\text { Program } \\
\text { Area }\end{array}$} & \multirow[t]{2}{*}{ Storage } & \multirow[t]{2}{*}{ Researchers } & \multirow[t]{2}{*}{ Arundhati Banerjee } \\
\hline & 0 & 0 & 0 & 41 & & & & \\
\hline
\end{tabular}

Objective:

To assess various onboard hydrogen storage technologies from the perspective of fuel cell vehicles.

Approach/Background:

Consider and evaluate the state of the art of various hydrogen storage systems in all three forms (i.e., solid, liquid, and gaseous) and their feasibility for use in fuel cell vehicles. Compare analysis of several newly proposed and more conventional storage systems.

Accomplishments/Status:

A critical assessment of various onboard hydrogen storage technologies from the perspective of fuel cell vehicles was completed. The state of the art of various hydrogen storage systems in all three forms (i.e. solid, liquid, and gaseous) has been considered and their feasibility for use in fuel cell vehicles has been evaluated. A comparative analysis of several newly proposed, as well as the more conventional, storage systems has also been made. The three criteria considered for this comparison were: technological status and technoeconomic viability of the storage systems; coherency factors for system integration of fuel cell and fuel storage modules; and characteristic features of the vehicle and the corresponding transportation sector.

Systems chosen for study included: compressed gas, liquid hydrogen, adsorption on activated carton, $\mathrm{Fe} / \mathrm{H}_{2} \mathrm{O}, \mathrm{Mg} / \mathrm{H}_{2} \mathrm{O}$, metal hydrides, polyhydrides and iquid chemical carriers. More specifically, hydride storage systems were compared with present and future competing hydrogen storage systems and their design goals have been defined. Finally, the candidacy of storage systems for fuel cell vehicles was evaluated based on expectations, designs, and primary nature of the vehicle.

In defining the state of the art of various storage technologies, four major criteria were chosen. They were: technological maturity, economic viability, infrastructural compatibility and operational safety of the system. More specifically, the storage systems were evaluated on the basis of following criteria:

- Energy density (volumetric and gravimetric) of the hydrogen carrier

- $\quad$ Temperature requirement of hydrogenation or dehydrogenation

- Onboard energy requirement of both hydrogenation and dehydrogenation processes

- Infrastructural compatibility

- Improvement potential over present systems

- $\quad$ Purity of the gas delivered

- System simplicity (minimum components with easy handling and replaceable quality)

- $\quad$ Compatibility towards fuel cells

- Response time for hydrogen delivery and refueling time

- Safety

Three of the above-mentioned criteria, i.e., dehydrogenation temperature, purity of the delivered hydrogen, and response time of the storage system, have been given highest priority with respect to the system integration between fuel cell and storage systems. Since fuel cells have been proposed for all transportation sectors, the suitability of storage systems was evaluated separately for light duty (passenger car, light duty truck), heavy duty (bus, heawy truck), and off-road locomotives.

The major conclusions and recommendations of the report were:

- With the present status of the technology, only three systems for onboard hydrogen storage are close to commercialization. They are compressed gas at high pressure (3-5 kpsi, composite cylinder), liquid hydrogen, and metal hydrides (low temperature hydrides).

Other $\mathrm{H}_{2}$ storage systems, such as cnyoadsorption and Fe/water and cryopressure storage, need system level improvement and verification before they can be seriously considered. Systems such as carbon nanotubules and polyhydrides are still in the basic research stages and need major improvement. Systems with liquid chemicals (methanol/methane) need a great deal of improvement in reformer design and catalyst technology to be viable.

No single storage technology will satisfy all the above-mentioned criteria for onboard storage of $\mathrm{H}_{2}$. In the wide spectrum of the transportation sector, with thousands of vehicles having different functions, no single technology can provide the best solution for all of these expectations. Therefore, the importance of the evaluation criteria will evidently be ranked differently by various transportation sectors. For example, for passenger cars, volume and weight are major factors, whereas for a locomotive, up to a certain level, volume and weight are not so critical. Locomotives can easily attach a separate car for carrying both the fuel cell and storage system without sacrificing any volume that is required for luggage/passenger transportation. In fact, the attachment of an extra car gives the benefit of four added axles which helps in weightaxle distribution. Similarly, for a bus with a compressed gas cylinder on the roof, safety is not so much of a factor, whereas a passenger car with compressed gas at the luggage space is highly susceptible to rear end collision. 


\begin{tabular}{|c|l|l|l|l|l|}
\hline $\begin{array}{c}\text { Taak } \\
\text { Thtie }\end{array}$ & $\begin{array}{l}\text { Systems Study of Metal Hydride } \\
\text { Storage Requirements }\end{array}$ & Contractor & $\begin{array}{l}\text { Florida Solar } \\
\text { Research Center }\end{array}$ & $\begin{array}{l}\text { Principal } \\
\text { investigator }\end{array}$ & Ali T-Raissi \\
\hline
\end{tabular}

Accomplishments/Status (continued):

-

Compressed gas storage offers the best deal in terms of weight, response time, onboard energy requirement and cost. With the modern day composite cylinders, it also offers a higher safely factor. It suffers from low volumetric density and the perception of being hazardous. It is suitable for use with all three fuel cell technologies (AFC, PAFC, and PEMFC).

Liquid hydrogen offers the highest energy density and high purity. It is compatible with AFC, PEMFC and PAFC systems. Its main limitations are the high cost of liquefaction, cryogenic handling hazards and high boil-off losses. It is only recommended for regular fleets controlled by a trained professional. Liquid hydrogen bears the least chance of wide acceptance as the fuel for passenger cars.

Metal hydrides offer high volumetric storage densities and the highest crashworthy structure - a virtue which will promote its wide acceptance as a fuel storage system. But metal hydrides suffer from excessive weight and very high cost. Currently only LTH systems are available for ready use. For fuel cell systems, their suitability depends on the choice of hydrides. Among LTH, systems based on Ti-Fe, LaNi, and TiVMn (Hydralloy C) groups stand a good chance for use in PEMFCVs and PAFCVs. On the other hand, magnesium hydrides will not be suitable for PEMFCVs, PAFCVs or AFCVs. The TiZrMn group and AB5 (MnNi5, LaNi5) groups with dehydrogenation temperature less than $50^{\circ} \mathrm{C}$ are good candidates for AFCVs, PEMFCVs and PAFCVs. Although for a constant cruise, the effect of weight of the storage system does not alfect the driving mileage drastically, weight does play an important role in determining the overall performance (acceleration time, fuel consumption, etc.) of the vehicle. Therefore, although metal hydrides offer the best safety feature, they are not good candidates for passenger cars or bus applications. The most probable and logical application for metal hydrides should be the off-road locomotives.

Cryoadsorption offers high volumetric density but suffers from low gravimetric density and temperature control problems. In addition, refueling time is long compared to other systems. It can be used with all three types of fuel cells. It does not appear suitable for passenger vehicles, but may be used in fleet applications.

Sponge ironwater system is unsuitable for AFC and PEMFC, but could work with PAFC, provided the system needs only $200^{\circ} \mathrm{C}$ for hydrogen generation.

Liquid chemical carriers do not appear promising for FCVs considering the total weight and cost of reformer. The response time of steam oxidation reformers is high, which makes the fuel delivery slower. Safety issues are also important. The highest hydrogen density carrier, liquid ammonia, is toxic and thereby unacceptable.

Among the three transportation sectors, light duty vehicle (passenger car, pick up truck), heavy duty vehicle (bus, truck), and off-road locomotives, bcomotives with fleet applications may be the best stanting options for launching fuel cell vehicles. Because of their high accommodative nature, locomotives can use a PAFC and metal hydride combination and may enjoy high safety and zero emission quality.

- For bus/tnuck applications with unpredicted driving schedules, compressed gas might be the best option, provided the safety issues are resolved On the other hand, for a bus with a predictable driving schedule run by trained personnel, liquid hydrogen can be used, provided refueling is properly scheduled.

Passenger cars face the greatest challenge as far as FCVs are concerned. The combined requirements of weight, volume, and safety make passenger cars the least favorable sector for applying combined fuel cell and hydrogen storage technology.

Publications/Awards:

None

Students associated with the Program (Undergraduate, Graduate, Post Doctoral):

Dr. Arundhati Banerjee (Post Doctoral fellow)

Future Directions/industry Interactions:

This project is not funded beyond its original one-year grant. However, at FSEC we continue our dialogue with leaders in this area in the U.S. (Arthur D. Little, Energy Partners) and elsewhere. Dr. Raissi will visit Professor Hideo Kameyarma at the Tokyo University of Agriculture and Technology in 1995 as per their invitation. He also will meet with Drs. Tanaka and Doi of the Environmental Energy Section of Solar Energy Utilization Technology Division at the Electrochemical Institute of MITI in Tsukuba. Of special interest is his meeting with Dr. Etsuo Akiba of the National Institute of Materials and Chemical Research, AIST, MITI, Tsukuba, a prominent metal hydride scientist. The main objective of these meetings is fo develop collaborative research with Japanese colleagues. 


\begin{tabular}{|c|c|c|c|c|c|c|c|c|}
\hline $\begin{array}{l}\text { Task } \\
\text { Tikle }\end{array}$ & \multicolumn{4}{|c|}{$\begin{array}{l}\text { High Efficiency Stationary Hydrogen } \\
\text { Storage }\end{array}$} & Contractor & Arthur D. Little, Inc. & $\begin{array}{l}\text { Principal } \\
\text { Investigator }\end{array}$ & Dr. Scott Hynek \\
\hline \multirow{2}{*}{$\begin{array}{l}\text { Task } \\
\text { Funding } \\
\text { (K\$) }\end{array}$} & FY91 & FY92 & FY93 & FYS4 & \multirow{2}{*}{$\begin{array}{l}\text { Hydrogen } \\
\text { Program } \\
\text { Area }\end{array}$} & \multirow[t]{2}{*}{ Storage } & \multirow[t]{2}{*}{ Researchers } & \multirow{2}{*}{$\begin{array}{l}\text { Ware Fuller } \\
\text { David Friedman }\end{array}$} \\
\hline & 0 & 0 & 0 & 254 & & & & \\
\hline
\end{tabular}

Objective:

To demonstrate a technology that will meet the DOE performance goais for utility pathways: storage efficiency of $75 \%$ and added cost of $50 \%$ of delivered hydrogen.

\section{Approach/Background:}

Magnesium hydride is an excellent hydrogen storage medium (inexpensive, high hydrogen weight percentage, high volumetric density) but for three problems, all addressed by this program:

1. High temperature heat needed to dehydride - Store heat of hydriding as heat of fusion in a phase change material (PCM), and retrieve it to provide heat of dehydriding.

2. Poor kinetics - Coat each particle of magnesium with a thin coating of nickel.

3. Susceptibility to poisoning - Coat each particle of magnesium with a thin coating of nickel.

Place nicketcoated magnesium pounder (NCMP) on the tube side, and $\mathrm{PCM}$ (a eutectic mixture of $\mathrm{NaCl}, \mathrm{KCl}$, and $\mathrm{MgCl}_{2}$ ) on the shell side, of a shell-and-tube heat exchanger.

Accomplishments/Status:

The NCMP/PCM reactor has been built and tested. The inefficiency of storage/retrieval is limited to a nominal pressure swing (storage pressure minus withdrawal pressure) and to thermal losses from the reactor. The storage efficiency goal has been met, and the added cost goal is reachable given bulk manufacture of the NCMP and the PCM.

The effects of repeated cycling remain to be determined.

Publications/Awards:

S. Hynek, Hydrogen Storage to Support Fuel Cell Vehicles, $5^{\text {th }}$ Annual U.S. Hydrogen Meeting, March 24, 1994

S. Hynek, W. Fuller \& D. Friedman, High Eficiency Stationary Hydrogen Storage, Annual Review of the DOE/OUT $\mathrm{H}_{2}$ Program, April 19, 1994

S. Hynek \& W. Fuller, Hydrogen Storage Within the Infrastructure, $10^{\text {th }}$ World Hydrogen Energy Conference, June 23, 1994

S. Hynek \& J. Bentley, Hydrogen: Infrastructure and On-Board Storage, Argonne National Laboratory Workshop, September 8, 1994

Students associated with the Program (Undergraduate, Graduate, Post Doctoral):

None, although David Friedman is in ADL's Research Assistant program, for those who wish to work for two years between undergraduate and graduate study.

Future Directions/Industry Interactions:

We plan to minimize temperature gradients within the reactor, and monitor for performance degradation with repeated cycling. We intend to explore with Ultramet (the manufacturer of the NCMP) the possibility of pilot plant-scale production of NCMP. We plan also to investigate the extent to which NCMP can (or can be made to) resist poisoning by chemical species (such as $\mathrm{CO}, \mathrm{CO}_{2}$, and $\mathrm{H}_{2} \mathrm{O}$ ) found in reformate. 


\begin{tabular}{|c|c|c|c|c|c|c|c|c|}
\hline $\begin{array}{l}\text { Task } \\
\text { Title }\end{array}$ & \multicolumn{4}{|c|}{$\begin{array}{l}\text { Develop Improved Metal Hydride } \\
\text { Technology for the Storage of } \\
\text { Hydrogen. }\end{array}$} & Contractor & $\begin{array}{l}\text { Energy Conversion } \\
\text { Devices, Inc. }\end{array}$ & $\begin{array}{l}\text { Principal } \\
\text { Investlgator }\end{array}$ & Krishna Sapru \\
\hline \multirow{2}{*}{$\begin{array}{l}\text { Task } \\
\text { Funding } \\
\text { (KS) }\end{array}$} & FY91 & FY92 & FY93 & FY94 & \multirow{2}{*}{$\begin{array}{c}\text { Hydrogen } \\
\text { Program } \\
\text { Area }\end{array}$} & \multirow[t]{2}{*}{ Storage } & \multirow[t]{2}{*}{ Researchers } & \multirow{2}{*}{$\begin{array}{l}\text { L. Ming } \\
\text { S. Ramachandran }\end{array}$} \\
\hline & 0 & 0 & 0 & 250 & & & & \\
\hline
\end{tabular}

Objective:

To develop superior and low-cost metal hydrides for the storage of hydrogen. Such hydrides will accelerate the commercialization of fuel cells and hydrogen fueled vehicles.

Approach/Background:

While metal hydrides provide a safe and compact method for the storage of hydrogen, there is a need for improved hydriding alloys since presently known alloys lack many of the desired properties. Our approach is to develop practical bulk production techniques for the synthesis of $\mathrm{Mg}$-based high-capacity alloys which we have previously prepared and tested in thin-film form.

Accomplishments/Status:

During 1994, ECD successfully prepared several disordered, multi-component Mg-based alloys in bulk form, with hydrogen storage capacities ranging between $4 \mathrm{wt} \%-5.7 \mathrm{w} . \%$. Atter 2100 hydrogen absorptiondesorption cycles there was no change in $\mathrm{H}$-storage capacity or kinetic behavior of the alloys. Preliminary tests have also shown resistance to poisoning by $\mathrm{H}_{2} / \mathrm{CH}_{4}$ and $\mathrm{H}_{2} / \mathrm{CO}$ gas mixtures. We are continuing to make progress in reducing the $\mathrm{H}$-desorption temperature.

\section{Publications/Awards:}

K. Sapru, L. Ming, S. Ramachandran, "Magnesium Mechanical Alloys for Hydrogen Storage” patent application filed.

K Sapru \& L. Ming, "Preparation \& Characterization of Mg (Fe,Al,Ni,Ti) Alloys for use as Hydrogen Storage Materials" pp. 273-281, Proceedings of the 1994 DOE/NREL Hydrogen Program Review, April 18-21, 1994, Livermore, CA.

K. Sapru, L. Ming, S. Ramachandran, "Study of the Hydrogen Storage Properties of Mg-Ni-Mo System Prepared by Mechanical Alloying" to be submitted for publication.

Students associated with the Program (Undergraduate, Graduate, Post Doctoral):

Mr. S. Ramachandran joined the program as a summer student in July 1994, and later joined as a full-lime employee. Under this program we have collaborated with Professor Claus Borgnakke of the University of Michigan who occasionally uses his students for the project.

Future Directions/industry Interactions

- Continue alloy optimization

- Prototype metal hydride bed design and testing incorporating the new alloys

- Interact with fuel cell manufacturers for future prototype product testing. 


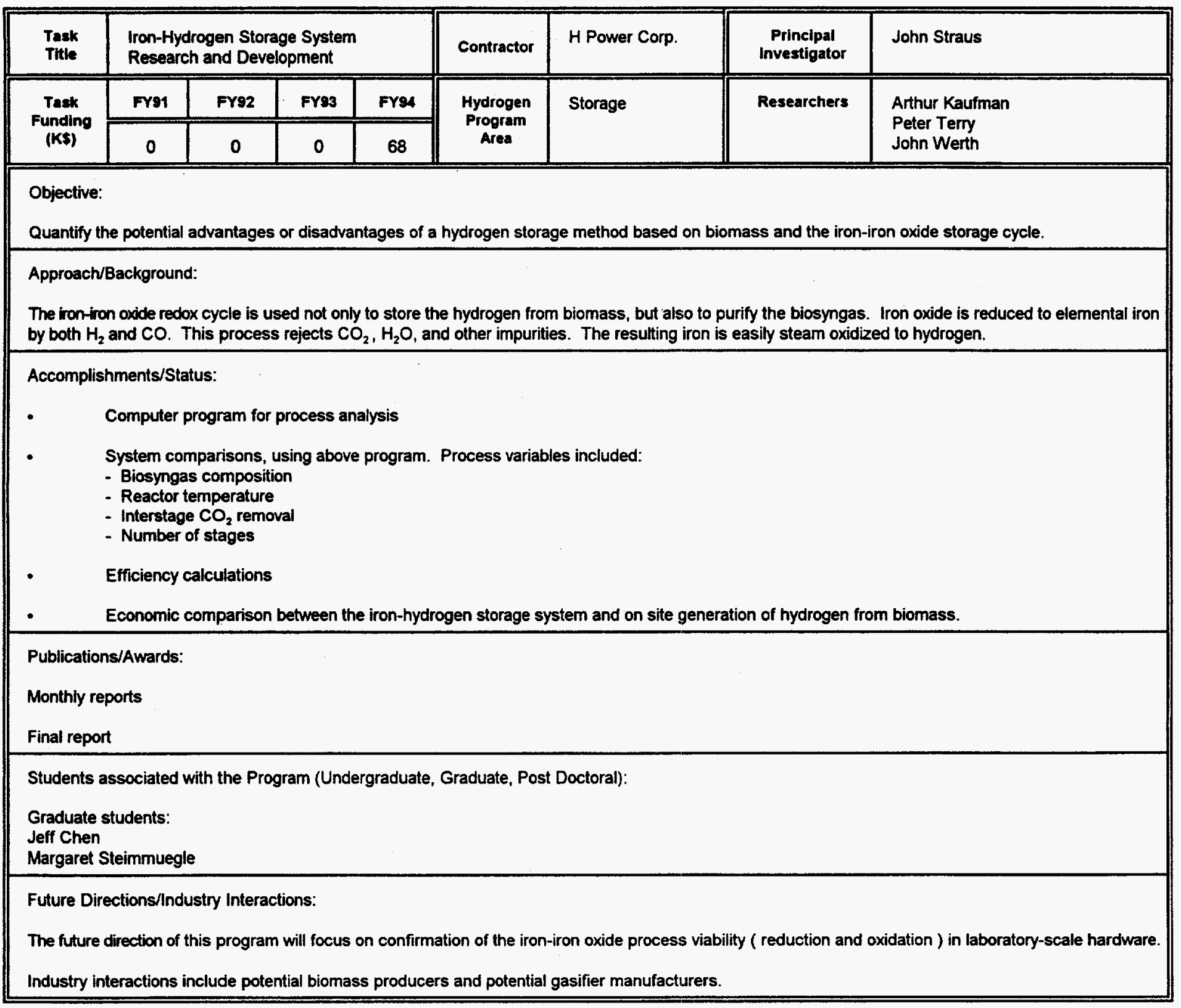




\begin{tabular}{|c|c|c|c|c|c|c|c|c|}
\hline $\begin{array}{l}\text { Task } \\
\text { Title }\end{array}$ & \multicolumn{4}{|c|}{$\begin{array}{l}\text { Research and Development of an } \\
\text { Optimized Hydrogen-Fueled Internal } \\
\text { Combustion Engine }\end{array}$} & Contractor & $\begin{array}{l}\text { Lawrence } \\
\text { Livermore National } \\
\text { Laboratory }\end{array}$ & $\begin{array}{l}\text { Principal } \\
\text { Investigator }\end{array}$ & J. Ray Smith \\
\hline \multirow{2}{*}{$\begin{array}{l}\text { Task } \\
\text { Funding } \\
\text { (K\$) }\end{array}$} & FY91 & FY92 & FY93 & FY94 & \multirow{2}{*}{$\begin{array}{l}\text { Hydrogen } \\
\text { Program } \\
\text { Area }\end{array}$} & \multirow[t]{2}{*}{ Utilization } & \multirow[t]{2}{*}{ Researchers } & \multirow[t]{2}{*}{ Salvador Aceves } \\
\hline & 0 & 0 & 0 & 50 & & & & \\
\hline
\end{tabular}

Objective:

The objective of this project is to develop the design guidelines for a hydrogen-fueled or hydrogen/natural gas-fueled, high-efficiency, low-emissions internal combustion engine for use in hybrid automobiles. These design guidelines will be validated by laboratory demonstration of a prototype hydrogen-fueled engine that exceeds $45 \%$ brake thermal efficiency with NOx emissions of less than $100 \mathrm{ppm}$ without an exhaust catalyst

\section{Approach/Background:}

This is a team effort of LLNL, Los Alamos National Laboratory. Sandia National Laboratories/ California, and a not-yet named industrial partner. LLNL will lead the development by doing vehicle simulation studies to size the hybrid engine and to establish the energy-equivalent mileage and the required hydrogen storage for a given range. The storage requirement, which is the quantity of hydrogen per refueling, will be used in infrastructure studies to size stations and distributed storage requirements and to estimate vehicle fuel operational costs. LLNL will design engine experiments to be performed by Sandia on existing research engines and will also design and fabricate research engine modifications to acquire necessary data. An earty task is to confirm literature data on indicated thermal efficiency and NOx emissions as a function of compression ratio and equivalence ratio. Emissions, indicated thermal efficiency and heat transfer losses in the engine experiments will be modeled by LANL using upgraded versions of KIVA-3 that employ improved kinetic packages from LLNL. The results of these experiments and simulations will be used to specify the combustion chamber geometry, engine speed, ignition system, and fuel delivery system to the engine manufacturer/industrial partner. The engine manufacturer will build the pre-prototype and prototype versions of the optimized engine using currently accepted industry standards and practices and assume the lead in friction-reduction efforts.

Accomplishments/Status:

During FY94 we completed vehicle simulation studies that indicate that $80-90$ miles-per-gailon energy-equivalent mileage is achievable using a series hybridelectric vehicle. Assuming a five-passenger sedan of 2,500 lb empty weight and industry recommendations for drag coefficient and cross-sectional area product, this automobile requires 3.5 to $4 \mathrm{~kg}$ of hydrogen for a 300 -mile range. A paper describing the vehicle simulation code and its application to the hydrogen hybrid sedan design has been accepted for presentation at the 1995 Society of Automotive Engineers Congress and Exposition.

Based on a detailed review of the hydrogen engine experiments in the literature, it is concluded that an optimized engine must be a homogeneous charge to keep NOx low, that heat-transfer losses are minimized at reduced combustion chamber surface-to-volume ratio (this implies a long-stroke engine), that acceptable friction is likely only at moderate engine speed $(<3600 \mathrm{rpm})$, and that specific power output will be low. This analysis will be presented in a paper at the SAE'94 Convergence Congress.

An engine experiment was designed using an existing Sandia research engine (Council for Lubrication Research engine) that demonstrated on neat hydrogen less than 5 pom NOx emissions at equivalence ratio of 0.35 for 8.25-13.7 compression ratios and 1200-2400 rpm. Exhaust gas temperatures were measured at over $300^{\circ} \mathrm{C}$ and therefore likely to be adequate for releasing hydrogen from advanced hydride storage systems. NOx emissions exceeded the target 100 $\mathrm{ppm}$ level at equivalence ratios of 0.5 but were below this level at equivalence ratio of less than 0.45 . Both $\mathrm{NO}$ and $\mathrm{NO}_{2}$ varied dramatically with ignition timing detays and equivalence ratio changes, respectively. This data may serve as a stringent test of the NOx kinetic model. The highest indicated thermal efficiency achieved was $42.5 \%$, which is well below literature values for the compression ratios used. This is thought to be due to high heat-transfer losses caused by the large "squish area" in this engine.

The design of an open chamber (no squish) cylinder head for the available Sandia Onan diesel engine is complete. This conversion of the diesel engine to a spark ignition engine uses dual ignition for the quiescent chamber design. Initial studies will be at 15:1 compression ratio. This configuration should allow direct comparison to similar experiments.

Publications/Awards:

None

Students associated with the Program (Undergraduate, Graduate, Post Doctoral):

Salvador Aceves, Postdoctoral Research Staff 


\begin{tabular}{|c|c|c|c|c|c|}
\hline $\begin{array}{l}\text { Task } \\
\text { Titie }\end{array}$ & $\begin{array}{l}\text { Research and Development of an } \\
\text { Optimized Hydrogen-Fueled Internal } \\
\text { Combustion Engine }\end{array}$ & Contractor & $\begin{array}{l}\text { Lawrence } \\
\text { Livermore National } \\
\text { Laboratory }\end{array}$ & $\begin{array}{c}\text { Principal } \\
\text { Investigator }\end{array}$ & J. Ray Smith \\
\hline \multicolumn{6}{|c|}{ Future Directions/Industry interactions: } \\
\hline \multicolumn{6}{|c|}{$\begin{array}{l}\text { We will have the Onan head design fabricated and will design the experiment parameter range. Both neat hydrogen and hydrogen/natural gas blends will be } \\
\text { used. The initial effort will be to achieve optimum burn duration (about } 30 \text { crank angle degrees, based on Japanese studies) using the dual ignition system. } \\
\text { After indicated themal efficiencies and emission data are measured, brake thermal efficiency (indicated efficiency minus engine friction) will be determined. } \\
\text { A series of experiments will then be designed to reduce engine friction by modifying the standard piston ring package while still achieving low blow-by and } \\
\text { low oil transport into the combustion chamber. The use of allernative lubricating oils will be considered. }\end{array}$} \\
\hline \multicolumn{6}{|c|}{$\begin{array}{l}\text { By midyear an industrial partner will be chosen to help refine the design specifications of the pre-prolotype of the optimized engine. A conceptual design review } \\
\text { will be held to get comments by hydrogen engine researchers and representatives of major automobile manufacturers. The drawings for the pre-prototype } \\
\text { engine will be made by the industrial partner and, because compromises are always necessary in a detail design, another design review will be held before } \\
\text { fabrication is started. The delivery of the pre-prototype engine to Sandia for testing will be targeted for the fourth quarter of Fyg5. }\end{array}$} \\
\hline \multicolumn{6}{|c|}{ Efforts in FY96 } \\
\hline \multicolumn{6}{|c|}{$\begin{array}{l}\text { In FY96, we plan to complete experiments on the pre-prototype engine and analyze the data for further optimization. The experimental results combined with } \\
\text { the KVA will be used to specify the prototype optimized engine. The industrial partner will do detail design and fabricate the prototype optimized engine and } \\
\text { deliver it to Sandia for testing by fourth quarter of FY96. }\end{array}$} \\
\hline \multicolumn{6}{|c|}{$\begin{array}{l}\text { We will request that the Califomia Alr Resources Board review the testing of the prototype engine on the dynamometer at Sandia and declare it Zero Emission } \\
\text { Vehicie equivalent technology. Concurrently we will request that CARB accept similar tests on hydrogen/natural gas blends as Ultra Low Emission Vehicle } \\
\text { equivalent technology. }\end{array}$} \\
\hline \multicolumn{6}{|c|}{ Efforts in FY97 } \\
\hline \multicolumn{6}{|c|}{$\begin{array}{l}\text { Four additional prototype optimized engines will be ordered from the industrial partner. One will be used at Sandia for long-term, life testing and to obtain wear } \\
\text { and late-life emission data. The other three engines will be made available for the OTT hybrid program or to any major U.S. automobile manufacturer that } \\
\text { would like to do their own evaluation. Detailed documentation of the design guidelines that were developed for optimizing the hybrid engine will be made } \\
\text { available to U.S. automotive manufacturers. }\end{array}$} \\
\hline
\end{tabular}




\begin{tabular}{|c|c|c|c|c|c|c|c|c|}
\hline $\begin{array}{l}\text { Task } \\
\text { Titie }\end{array}$ & \multicolumn{4}{|c|}{$\begin{array}{l}\text { Hydrogen Utilization in Internal } \\
\text { Combustion Engines }\end{array}$} & Contractor & $\begin{array}{l}\text { Sandia National } \\
\text { Laboratories/CA }\end{array}$ & $\begin{array}{l}\text { Principal } \\
\text { investigator }\end{array}$ & Peter Van Blarigan \\
\hline \multirow{2}{*}{$\begin{array}{l}\text { Task } \\
\text { Funding } \\
\text { (KS) }\end{array}$} & FY91 & FY92 & FY93 & FY94 & \multirow{2}{*}{$\begin{array}{c}\text { Hydrogen } \\
\text { Program } \\
\text { Area }\end{array}$} & \multirow[t]{2}{*}{ Utilization } & \multirow[t]{2}{*}{ Researchers } & \multirow{2}{*}{$\begin{array}{l}\text { J.D. Naber } \\
\text { D. L. Siebers } \\
\text { Bob Green } \\
\text { J. Ray Smith (LLNL) }\end{array}$} \\
\hline & 0 & 0 & 0 & 600 & & & & \\
\hline
\end{tabular}

Objective:

To develop and demonstrate hydrogen utilization technologies that will establish hydrogen as an alternative energy carrier. Near term, the objective is to specify engine design parameters and operating conditions for use of hydrogen fuels in internal combustion engines suitable for use in a series-type, hybrid-passenger vehicle. This engine will then be demonstrated in an integrated internal combustion engine/electric generator/energy storage/fuel storage/propulsion electric motor package for said series-type, hybrid-passenger vehicle.

Approach/Background:

A key to the introduction of hydrogen into the U.S. energy supply is the development of efficient and reliable utilization systems. In the short term, the use of hydrogen-burning, reciprocating internal combustion engines with high brake thermal efficiency and which meet low emission goals will be essential.

The goal of this project is to optimize thermal efficiency for application in a series-type, hybrid-passenger vehicle, while also meeting ultra low emission vehicle (ULEV) requirements as defined by the California Air Resources Board (CARB). Note that this is a restructuring of our original program in order to be more responsive to the needs of the hydrogen community. The efficiency goal is to meet the standards set by the Partnership for a New Generation of Vehicles (PNGV for the long term, next generation vehicle. The engine development will be an experimental effort conducted by Sandia National Laboratory/California in collaboration with Lawrence Livermore National Laboratory and Los Alamos National Laboratory, requiring three years.

First, experiments will be run in existing research engines to investigate suitable operating regimes for hydrogen operation. The second phase will involve designing with an industrial partner new research engines to investigate at realistic power $(25 \mathrm{~kW})$ the parameters that affect efficiency and emissions. This will lead to the design, again with an industrial partner, and procurement of an optimized engine for the series type hybrid application.

Accomplishments/Status:

\section{Heawy Duty Direct Injection Hydrogen Engine Investigation}

Experimental tests of hydrogen ignition and combustion under direct-injection conditions for utilization in heavy duty internal-combustion engines were made. The autoignition and combustion experiments were performed in the diesel combustion simulation laboratory at the Combustion Research Facility, Sandia National Laboratories. The facility allows the observation and study of the combustion processes occurring in heavy duty engines over all engine compression ratios and inlet conditions.

The autoignition of hydrogen at injection pressures from 14 to $28 \mathrm{MPa}$ was studied over a range of ambient gas pressures ( 2 to $15 \mathrm{MPa}$ ), temperatures $(950-1300 \mathrm{~K})$, and dilution $\left(21 \%-5 \% \mathrm{O}_{2}\right)$. These tests show that compression ignition of hydrogen under direct-injection conditions is possible at reasonable top-dead-center engine conditions $(T=1050-1100 \mathrm{~K}, \mathrm{p}=6.1 \mathrm{MPa})$ even for the maximum dilution studied $\left(5 \% \mathrm{O}_{2}\right)$.

In addition to the autoignition studies, a series of high speed imaging investigations of non-combusting and combusting hydrogen jets issuing from the high pressure fuel injector were completed. These studies quantify the global mixing processes occurring in these transient fuel jets, providing data to fuel injector and engine designers for combustion system optimizations.

\section{Low NOX Emissions from CLR Engine}

A single cylinder CLR engine was configured to run on pure hydrogen at Sandia National Laboratory/California's Combustion Research Facility. Experiments were performed to investigate $\mathrm{NO}_{\mathrm{x}}$ production, the principal emission from hydrogen-fueled engines, as a function of equivalence ratio, compression ratio, rotary speed and spark timing.

This engine was operated in an unthrottled spark ignited mode at three compression ratios $(8.25,11.1,13.7)$, three speeds (1200, $1800,2400 \mathrm{rpm})$, and equivalence ratios ranging from 0.3 to 0.5 . The compression ratio was increased by a boss on top of the piston, reducing the clearance volume, thus maintaining a constant displacement. Hydrogen and air were well mixed before entering the engine for all conditions.

The $\mathrm{NO}_{\mathrm{x}}$ emissions measured were less than five parts per million for all compression ratios and speeds at an equivalence ratio of 0.35 , values which are well below the ULEV standards for this application. Indicated efficiencies, as determined from cylinder pressure measurements, were less than expected, possibly due to compression volume geometry.

\section{Flat Head Research Engine Design}

To understand the effect of combustion chamber geometry on indicated thermal efficiency, a new cylinder head was designed by LLNL with collaboration with the University of Miami for Sandia's single-cylinder Onan diesel research engine. The head is flat as is the piston crown, resulting in a no "squish" zone. Testing will begin in FY95 with premixed hydrogen and air, utilizing two sparkplugs for ignition. 


\begin{tabular}{|c|c|c|c|c|c|}
\hline $\begin{array}{l}\text { Task } \\
\text { Titie }\end{array}$ & $\begin{array}{l}\text { Hydrogen Utilization in Internal } \\
\text { Combustion Engines }\end{array}$ & Contractor & $\begin{array}{l}\text { Sandia National } \\
\text { Laboratories/CA }\end{array}$ & $\begin{array}{l}\text { Principal } \\
\text { Investigator }\end{array}$ & Peter Van Blarigan \\
\hline $\begin{array}{l}\text { Publica } \\
\text { None }\end{array}$ & Awards: & & & & \\
\hline \multicolumn{6}{|c|}{$\begin{array}{l}\text { Students associated with the Program (Undergraduate, Graduate, Post Doctoral): } \\
\text { None }\end{array}$} \\
\hline $\begin{array}{l}\text { Future } 1 \\
\text { Sandia's } \\
\text { will be p } \\
\text { optimize }\end{array}$ & $\begin{array}{l}\text { tions/Industry Interactions: } \\
\text { erimental program involving the r } \\
\text { ed with all collaborators and an ir } \\
\text { ototype engine for the series type }\end{array}$ & $\begin{array}{l}\text { vill be develo } \\
\text { her. It is anti } \\
\text { ation in FY9 }\end{array}$ & $\begin{array}{l}\text { in the beginning } \\
\text { ted to evolve thro }\end{array}$ & $\begin{array}{l}\text { 995. Concur } \\
\text { generations }\end{array}$ & $\begin{array}{l}\text { a full scale research engine design } \\
\text { search engines prior to obtaining the }\end{array}$ \\
\hline
\end{tabular}




\begin{tabular}{|c|c|c|c|c|c|c|c|c|}
\hline $\begin{array}{l}\text { Task } \\
\text { Trite }\end{array}$ & \multicolumn{4}{|c|}{$\begin{array}{l}\text { Chemical Kinetic Modeling of } \mathrm{H}_{2} \\
\text { Applications }\end{array}$} & Contractor & $\begin{array}{l}\text { Lawrence } \\
\text { Livermore National }\end{array}$ & $\begin{array}{l}\text { Principal } \\
\text { Investigator }\end{array}$ & Charles K. Westbrook \\
\hline \multirow{2}{*}{$\begin{array}{l}\text { Task } \\
\text { Funding } \\
\text { (K\$) }\end{array}$} & FY91 & FY92 & FY93 & FYs4 & \multirow{2}{*}{$\begin{array}{c}\text { Hydrogen } \\
\text { Program } \\
\text { Area }\end{array}$} & \multirow[t]{2}{*}{ Utilization } & \multirow[t]{2}{*}{ Researchers } & \multirow{2}{*}{$\begin{array}{l}\text { L. Cloutman } \\
\text { N. Marinov }\end{array}$} \\
\hline & 0 & 0 & 0 & 200 & & & & \\
\hline
\end{tabular}

Objective:

The objective of this work is to develop more detailed kinetic models to be used for hydrogen applications.

Approach/Background:

This project includes two principal elements. In the first approach, the physical geometry of the combustion system is simplified to deal with a zero or onedimensional formulation. This makes it possible then to deal in great detail with selected subprocesses, including the detailed chemical kinetics of fuel axidation, $\mathrm{NO}_{\mathrm{x}}$ production, and pollutant emission. On the other hand, it is also possible to simplify the detailed chemical and physical process submodels and deal in detail with the multidimensional fuid mechanics. Both approaches have been used extensively in the past to study combustion in practical systems, including particularty internal combustion engines. In the present program, both approaches are being pursued, using current models for complex chemical kinetics and multidimensional fluid mechanics. As our program develops in time, it will eventually become feasible to combine both features together and carry out model analyses on a scale that was not possible previously, eventually moving the modeling work onto massively parallel computers.

Accomplishments/Status:

LLNL has carried out kinetic and fluid mechanical models that both advance our current capabilities and also address specific applications problems. in the area of simplified fluid mechanics modeling, we have examined a number of problems associated with hydrogen oxidation. We have also developed and applied simplified kinetic submodels for use within complex fluid mechanics models.

This general approach will be continued in the coming years within this program. This work will be coordinated with other research activities at LLNL, at Sandia National Laboratories, and other projects within the DOEJOUT program.

Publications/Awards:

Gray, J.A. and C.K. Westbrook, "High Temperature Ignition of Propane with MTBE as an Additive: Shock Tube Experiments and Modeling," Intemational Joumal of Chemical Kinetics, in press (1994).

Bozzeli, J.W. and W.J. Pitz, "The Reaction of Hydroperoxy-Propyl Radicals with Molecular Oxygen," Submitted to the 25th International Symposium on Combustion, August 1994.

Naber, J.D, D.L. Siebers, S.S. Di Julio, and C.K. Westbrook, "Effects of Natural Gas Composition on Ignition Delay under Diesel Conditions," Submitted to the 25th International Symposium on Combustion, August 1994.

Ranzi, E., A. Sogaro, P. Gaffuri, G. Pennati, C.K. Westbrook, and W.J. Pitz, "A New Comprehensive Reaction Mechanism for Combustion of Hydrocarbon Fuels," Submitted to the 25th International Symposium on Combustion, August 1994.

Pitz, W.J., C.K. Westbrook, A.E. Lutz, R.J. Kee, S. Senkan, and J.G. Seebold, "Numerical Modeling Capabilities for the Simulation of Toxic By-Products Formation of Combustion Processes," Third International Congress on Toxic Combustion By-Products, Cambridge, MA, June 1993. Combustion Science and Technology, in press (1994).

Naber, J.D., D.L. Siebers, S.S. Di Julio, and C.K Westbrook, "Natural Gas Fuel Variability Effects on Ignition Delay Under Diesel Conditions," Western States Section of the Combustion Institute, Menlo Park, California, October 1993.

Cloutman, L.D. and L. Brookshaw, "Numerical Simulation of Radiative Heat Loss in an Experimental Burner," Western States Section of The Combustion Institute, Menlo Park, California, October 1993. LLNL Report UCRL-JC-115048.

Students associated with the Program (Undergraduate, Graduate, Post Doctoral):

N. Marinov (Post Doctoral) 


\begin{tabular}{|c|c|c|c|c|c|}
\hline $\begin{array}{l}\text { Task } \\
\text { Title }\end{array}$ & $\begin{array}{l}\text { Chemical Kinetic Modeling of } \mathrm{H}_{2} \\
\text { Applications }\end{array}$ & Contractor & $\begin{array}{l}\text { Lawrence } \\
\text { Livermore National } \\
\text { Laboratory }\end{array}$ & $\begin{array}{l}\text { Principal } \\
\text { Investigator }\end{array}$ & Charies K. Westbrook \\
\hline \multicolumn{6}{|c|}{ Future Directions/lndustry Interactions: } \\
\hline \multicolumn{6}{|c|}{ Some of the above activities will be continued into FY95 and other new activities will be initiated. These include the following: } \\
\hline - & \multicolumn{5}{|c|}{$\begin{array}{l}\text { Detalied Kinetic Modeling - We are using our detailed models to examine conditions related to the recent engine experiments carried out at Sandia } \\
\text { with hydrogen fuel. The experiments examined very lean conditions and focused on production of NO, in the engine. We are combining our detailed } \\
\text { linetic model with the current best kinetics for NO, chemistry to see what reactions are most important in determining the NOx production under } \\
\text { these conditions. We are also calculating the results of adding small amounts of other fuels, especially methane and natural gas, but also other } \\
\text { species as well. This work will be completed by December } 1994 \text {. }\end{array}$} \\
\hline - & \multicolumn{5}{|c|}{$\begin{array}{l}\text { Model Development - We will complete our tests of the composite model of KIVA with detailed kinetics for hydrogen by January } 1995 \text {. We will then } \\
\text { begin to use that model in several interrelated studies. These will include using hydrogen as a fuel in internal combustion engines. We will attempt } \\
\text { to use the same engine model as used in previous LANL studies, which used global reaction models. We will aiso examine in detail hydrogen } \\
\text { oxidation in burners similar to those currently being simulated with a global kinetics mechanism. These studies will begin once the model itself has } \\
\text { been tested, as noted above, and should be completed by the end of FY95. }\end{array}$} \\
\hline - & \multicolumn{5}{|c|}{$\begin{array}{l}\text { Colorado State University - A group at CSU is building large-scale internal combustion engines and using mixtures of natural gas and hydrogen } \\
\text { as fuel. They have asked LLNL to do some preliminary two-dimensional calculations to suggest optimal operational conditions for these engines, } \\
\text { and we have provided them with some information and a few computed sets of results. We expect this effort to continue at a relatively low level } \\
\text { in FY95 and feel that this is an appropriate minor task to carry out within the DOE/OUT program. }\end{array}$} \\
\hline - & \multicolumn{5}{|c|}{$\begin{array}{l}\text { LLNL Hytrid Engine Effort - We expect to provide computational support for this concurrent reseach project during FY95. This work will explore } \\
\text { optimal operating conditions for this engine to minimize } \mathrm{NO}_{x} \text { production and maximize efficiency. As other issues arise we will work closely with } \\
\text { this project to resolve issues that relate to combustion questions. }\end{array}$} \\
\hline \multicolumn{6}{|c|}{ Efforts in FY96 and FY97 } \\
\hline \multicolumn{6}{|c|}{$\begin{array}{l}\text { As the massively parallel version of KIVA and its related other codes becomes available with detailed submodels for chemical kinetics, we will continue to use } \\
\text { that model to examine hydrogen combustion in practical systems. The emphasis of our work, as always, will be to identify physical and chemical mechanisms } \\
\text { that lead to improved performance and reduced pollutant emissions. Hydrogen reaction mechanisms will be combined with NO } \mathrm{x}_{\mathrm{x}} \text { reaction mechanisms, along } \\
\text { with hydrocarbon systems in applications where that is appropriate. We would be available to collaborate with other projects supported by DOE/OUT where } \\
\text { it is appropriate and mutually productive. }\end{array}$} \\
\hline
\end{tabular}




\begin{tabular}{|c|c|c|c|c|c|c|c|c|}
\hline $\begin{array}{l}\text { Task } \\
\text { Title }\end{array}$ & \multicolumn{4}{|c|}{$\begin{array}{l}\text { Hydrogen Program Combustion } \\
\text { Research, Three Dimensional } \\
\text { Computer Modeling }\end{array}$} & Contractor & $\begin{array}{l}\text { Los Alamos } \\
\text { National Laboratory }\end{array}$ & $\begin{array}{c}\text { Principal } \\
\text { Investigator }\end{array}$ & T. Daniel Butler \\
\hline \multirow{2}{*}{$\begin{array}{l}\text { Task } \\
\text { Funding } \\
\text { (K\$) }\end{array}$} & Fre1 & FY92 & FY93 & FY94 & \multirow{2}{*}{$\begin{array}{c}\text { Hydrogen } \\
\text { Program } \\
\text { Area }\end{array}$} & \multirow[t]{2}{*}{ Utilization } & \multirow[t]{2}{*}{ Researchers } & \multirow{2}{*}{$\begin{array}{l}\text { A.A. Amsden } \\
\text { N.L. Johnson }\end{array}$} \\
\hline & 0 & 0 & 0 & 350 & & & & \\
\hline
\end{tabular}

Objective:

The work Los Abamos National Laboratory (LANL) supports industry collaboration in the DOE Hydrogen Program in two areas by developing the knowledge to enable industry and government laboratories: (1) to build a stationary, hydrogen-fueled internal combustion engine to power an electric generator system, and (2) to build an advanced internal combustion engine fueled by hydrogen to meet zero emission requirements. Our objectives are to demonstrate by means of comparisons with test data, the utility of the computational approach in the overall research program to develop such internal combustion engines and then to collaborate with industry in their applications of the computer models. We also will be responsive to resolving critical design issues as our capability evolves and as issues arise in the progress of the Sandia National Laboratory (SNL) and Lawrence Livermore National Laboratory (LLNL) programs.

Approach/Background:

Our approach is to refine, modify and utilize state-of-the-art computer models, embodied in the KIVA-3 and KIVA-F90 computer codes, developed at Los Alamos for internal combustion engines operating on hydrocarbon fuels, to facilitate the analysis of combustion with both pure hydrogen fuel and fuel mixtures of hydrogen and hydrocarbon gases. LANL will use the chemistry submodels under development at LLNL. The hydrogen combustion simulation capability can then be benchmarked with experiments performed by SNL and LLNL and then be used to aid in the support of the development of the optimized test engine and demonstration engine also planned by SNL and LLNL. Because of the wide use of KIVA in the automotive, diesel and aerospace industries, the capability to use hydrogen fuel can be quickly utilized by industry. Transfer of the modeling capability to industry and other government laboratories will occur as the capability and need evolve.

Accomplishments/Status:

Summary

The DOE Hydrogen Program at Los Alamos, initiated in January 1994, has focused to date on three areas: (1) the simulation of hydrogen injection and combustion, and comparison to the SNL data, (2) the simulation of the spark-ignited, two-stroke CLR engine and comparison with data and (3) the implementation of a vertical valve capability into KIVA-3 and the development of the accompanying mesh generation capability.

Modeling and Simulation of Hydrogen Injection and Combustion

Our studies of the SNL hydrogen injection experiments are completed. We found that the hydrogen injection problem is comparable in computational difficulty to the liquid fuel diesel injection problem. We outlined a computational approach that divided the injection flow into tractable problems that can be analyzed separately and then sequentially coupled. The approach obtained good agreement with the hydrogen penetration data using a highly resolved, threedimensional mesh. A similar approach to hydrogen injection is not feasible using the coarse mesh resolutions typically required by large-scale engine simulations as used by industry. Hence the current studies are limited by execution time and computer memory in the duration and complexity of the problem that can be examined. We have outlined an approach for hydrogen injection on coarse meshes based on existing computational approaches for liquid fuel injection. Although the engine design is now focused on homogeneous-charged engines, an efficient computational approach to hydrogen injection remains an issue in hydrogen-fuel designs as a means of premixing the hydrogen with air.

We examined alternatives to modeling the combustion of hydrogen using a single-step reaction and a 22-equation reaction model. Comparisons to the SNL combustion data were made, and it was found that experimentally determined autoignition delay times must be specified to reproduce the experimental results. This indicates a deficiency in the chemical kinetics for the hydrogen combustion. From these studies we conclude that: (1) the hydrogen jet penetration with combustion is comparable to the penetration without combustion, (2) the pressure rise and penetration compares well with the SNL experiment, (3) the two approaches to combustion performed similarty, with the single step oxidation running 3.2 times faster and producing a stightly higher pressure rise as a result of the absence of equilibrium chemistry, (4) the hydrogen buming rate reached steady-state conditions very quickly (0.05 ms after ignition), (5) the 22-reaction set alone severely underpredicts the experimental autoignition time $(0.05 \mathrm{~ms}$ vs. $0.355 \mathrm{~ms})$, and (6) NO production could be reasonably calculated using the standard Zeldovich mechanism.

\section{Modeling of Homogeneous-Charged, Spark-Ignited Engines}

KVA 3 simulations were performed of the monocylinder, two-stroke engine (CLR engine), tested by SNL-CA. Because of the absence of a valve model in KIVA at the time, the inlet and exhaust valves were not included in the mesh description. The engine was examined at two different mesh resolutions to evaluate the effect of combustion on mesh size. We observed that for the two mesh resolutions, different constants in the chemical kinetics are required to match the time of peak pressure in the experiments. But within a given mesh size, the same kinetic constants match the time of the peak pressure for different ignition times. Pressure histories have been compared to experiments, and the breadth of the peak pressure pulse is narrower in the computation than in the experiment. The dependence of the $\mathrm{NO}_{x}$ production on the changes in ignition timing is described qualitatively, but not quantitatively, when compared to the experiments. We attribute both of these discrepancies to the absence a mixing-controlled combustion model in the simulations. 


\begin{tabular}{|c|c|c|c|c|c|}
\hline $\begin{array}{l}\text { Task } \\
\text { Thie }\end{array}$ & $\begin{array}{l}\text { Hydrogen Program Combustion } \\
\text { Research, Three Dimensional } \\
\text { Computer Modeling }\end{array}$ & Contractor & $\begin{array}{l}\text { Los Alamos } \\
\text { National Laboratory }\end{array}$ & $\begin{array}{l}\text { Principal } \\
\text { Investigator }\end{array}$ & T. Daniel Butler \\
\hline
\end{tabular}

Accomplishments/Status (continued):

We have begun to apply a mixing-controlled combustion model to the simulations of the CLR engine using KIVA-3. Previously we had observed that the combustion in the simulations of the CLR engine were prone to run-away temperatures typical of using Arrhenius kinetics. Presently the inclusion of the moxing-controlled combustion in the simulations results in limited or no combustion occurring. Although we have not specifically identified the problem, we suspect that the absence of including valve opening and closing in the simulation results in a low level of turbulence at the time of combustion and consequently, llmited combustion.

\section{Implementation of Valve Model into KIVA-3}

In order to better describe the flow field at the time of spark ignition, the intake of air and the release of exhaust gases through the valves must be modeled. To this end, a valve model has been implemented in KIVA-3. The current model is restricted to valves that move in the same direction as the piston; the removal of this restriction is under investigation. The implementation of the valve model is compatible with all previous features. A valve model in KIVA-3 significantly extends the applicability of KIVA to valved engines, which includes all the planned homogeneous-charged, spark-ignited engines by SNL and LLNL, with the exception of the two-stroke, opposed-piston engine that uses ports. This implementation will become a standard option in KIVA-3 and will be available to other participants of the project. The mesh generation code for KIVA was modified to include the addition of valves.

Using the new version of KIVA, we have duplicated the results of an isothermal, two-valve engine simulation done by University of Wisconsin for a diesel engine. The simulation using a 122,000-zone mesh took 11.5 hours on a Cray YMP8/128, compared to the 25 hours with original implementation by Hessel on a comparable computer. The significant decrease in run time is due to a much faster sorting routine and elimination of an interpolation error in the original implementation

\section{Modeling of Homogeneous-Charged, Spark-Ignited Engines}

KIVA-3 simulations were performed on the monocylinder, two-stroke engine (CLR engine), tested by SNL-CA. Because of the absence of a valve model in KIVA at the time, the inlet and exhaust valves were not included in the mesh description. The engine was examined at two different mesh resolutions to evaluate the effect of combustion on mesh size. We observed that for the two mesh resolutions, different constants in the chemical kinetics are required to match the time of peak pressure in the experiments. But within a given mesh size, the same kinetic constants match the time of the peak pressure for different ignition times. Pressure histories have been compared to experiments, and the breadth of the peak pressure pulse is narrower in the computation than in the experiment. The dependence of the $\mathrm{NO}_{x}$ production on the changes in ignition timing is described qualitatively, but not quantitatively, when compared to the experiments. We attribute both of these discrepancies to the absence a mixing-controlled combustion model in the simulations.

We have begun to apply a mixing-controlled combustion model to the simulations of the CLR engine using KIVA-3. Previously we had observed that the combustion in the simulations of the CLR engine were prone to run-away temperatures typical of using Arrhenius kinetics. Presently the inclusion of the mioing-controlled combustion in the simulations results in limited or no combustion occurring. Although we have not specifically identified the problem, we suspect that the absence of including valve opening and closing in the simulation results in a low level of turbulence at the time of combustion and, consequently, limited combustion.

\section{Implementation of Valve Model into KIVA-3}

In order to better describe the flow field at the time of spark ignition, the intake of air and the release of exhaust gases through the valves must be modeled. To this end, a valve model has been implemented in KIVA-3. The current model is restricted to valves that move in the same direction as the piston; the removal of this restriction is under investigation. The implementation of the valve model is compatible with all previous features. A valve model in KIVA-3 significantly extends the applicability of KJVA to valved engines, which includes all the planned homogeneous-charged, spark-ignited engines by SNL and ULN, with the exception of the two-stroke, opposed-piston engine that uses ports. This implementation will become a standard option in KIVA-3 and will be available to other participants of the project. The mesh generation code for KIVA was modified to include the addition of valves.

Using the new version of KIVA, we have duplicated the results of an isothermal, two-valve engine simulation done by University of Wisconsin for a diesel engine. The simulation using a 122,000-zone mesh took 11.5 hours on a Cray YMP8/128, compared to the 25 hours with original implementation by Hessel on a comparable computer. The significant decrease in run time is due to a much faster sorting routine and elimination of an interpolation error in the original implementation.

Publications/Awards:

None

Students associated with the Program (Undergraduate, Graduate, Post Doctoral):

None 


\begin{tabular}{|c|l|l|l|l|l|}
\hline $\begin{array}{c}\text { Task } \\
\text { Title }\end{array}$ & $\begin{array}{l}\text { Hydrogen Program Combustion } \\
\text { Research, Three Dimensional } \\
\text { Computer Modeling }\end{array}$ & Contractor & $\begin{array}{l}\text { Los Alamos } \\
\text { National Laboratory }\end{array}$ & $\begin{array}{c}\text { Principal } \\
\text { Investigator }\end{array}$ & T. Daniel Butler \\
\hline
\end{tabular}

Future Directions/industry interactions:

The DOE Hydrogen Program at LANL extends to September 1997 and includes the continued modeling and testing of the KIVA codes for hydrogen combustion. Parallel with this task is the transfer of the technology to other government laboratories and industry. The specific plans for the project are as follows:

- The dynamics of the two-stroke CLR and four-stroke Onan engines being tested at SNL will be analyzed using KIVA-3. Comparison to operating efficiencies and $\mathrm{NO}_{x}$ formation will be made. Once the simulations are validated, an analysis of the operation of the engine will be made to better understand the experimental observations of the effect of combustion chamber geometry, turbulence levels, flame speed, and heat transfer on efficiency and $\mathrm{NO}_{\mathrm{x}}$ formation.

-

The detailed and simplified hydrogen combustion chemistry models as developed by LLNL will be implemented in KIVA-3 and KIVA-F90. The validity of the models will be tested by comparison to the SNL engine data. The range of applicability of the simplified chemistry, which is essential for full engine simulations, will be evaluated by comparisons to engine simulations using the detailed hydrogen chemistry.

KIVA-FSO, the massively-parallel version of KIVA, will be applied to design problems that require long run times or highly resolved meshes. Simulations using KIVA-F9O on massively parallel computers and clusters of workstations can examine significantly more detailed problems with faster run times and reduced cost. These calculations will be a demonstration to industry of the significantly increased capability afforded by massively-parallel architectures or clusters of workstations.

- LANL will aid in evaluation of a two-stroke, opposed-piston design being suggested by SNL and LLNL, using the LANL experience in an ongoing program for a similar ARPA design based on diesel fuel injection. This effort takes advantage of the standard option in KIVA-3 for modeling two-piston engines.

The development and analysis of the $1 \mathrm{MW}$ hydrogen and hydrogen-mixture burner for utility and residential stationary sources will be evaluated. We will take advantage of the current LANL program for the NASA steady-state combustor, in particular the techniques used to speed the approach to steady-state using local time-stepping in KIVA.

Ongoing with the development and testing of the KVA codes, the modeling capabilities will be transferred to industry and other government laboratories. The process has begun with discussions with potential industrial partners, proceed with the transfer of appropriate versions of KIVA with extensions for hydrogen combustion, and conclude with support of the development of hydrogen-fueled engines. 


\begin{tabular}{|c|c|c|c|c|c|c|c|c|}
\hline $\begin{array}{l}\text { Task } \\
\text { Titie }\end{array}$ & \multicolumn{4}{|c|}{$\begin{array}{l}\text { Technical and Economic Assessments } \\
\text { of the Transport and Storage of } \\
\text { Hydrogen }\end{array}$} & Contractor & $\begin{array}{l}\text { Lawrence } \\
\text { Livermore National } \\
\text { Laboratory }\end{array}$ & $\begin{array}{c}\text { Principal } \\
\text { Investigator }\end{array}$ & Robert N. Schock \\
\hline \multirow{2}{*}{$\begin{array}{l}\text { Task } \\
\text { Funding } \\
\text { (K\$) }\end{array}$} & FY91 & FY92 & FY98 & FY94 & \multirow{2}{*}{$\begin{array}{c}\text { Hydrogen } \\
\text { Program } \\
\text { Area }\end{array}$} & \multirow[t]{2}{*}{ Utilization } & \multirow[t]{2}{*}{ Researchers } & \multirow{2}{*}{$\begin{array}{l}\text { Gene D. Berry } \\
\text { Pamela Campos }\end{array}$} \\
\hline & 0 & 0 & 0 & 100 & & & & \\
\hline
\end{tabular}

Objective:

This project seeks to estimate delivered hydrogen costs at each step in energy transmission, storage, and distribution and to identify promising low-cost hydrogen energy pathways, particularly early in a transition to hydrogen vehicles.

\section{Approach/Background:}

We are performing integrated technical and economic assessments of present and future hydrogen technologies so as to estimate the delivered costs at each step in energy transmission, storage, and distribution. We are attempting to identify promising low-cost hydrogen energy pathways, particularly early in a transition to hydrogen vehicles. In addition to microeconomic parameters, the issues of market size and structure, infrastructure vulnerability, market flexibility, energy efficiency, and time scales are being addressed, all in the context of the existing energy infrastructure. Alternative options for hydrogen delivery, such as local hydrogen production using small-scaie electrochemical or thermochemical methods, are also being examined as a viable first stage of a smooth transition to hydrogen.

The lack of an infrastructure to supply hydrogen at a competitive price and in a form compatible with the utilization technology is the chief barrier to the introduction of hydrogen as an alternative fuel. Such an infrastructure helps determine not only price but also the absolute availability of fuel. Investments in today's energy infrastructure are already-sunk costs, and a future energy infrastructure will require market risks not faced by energy suppliers within the current infrastructure. A smooth hydrogen transition will require a good match among technologies, markets, consumers, and producers. The pathway from production to end-use must be well-integrated in temporal, economic, and technological terms. To accomplish this, hydrogen infrastructure systems need to be analyzed and evaluated using a consistent and clear methodology. The results of an infrastructure analysis will allow planning for transitional strategies that can achieve rapid energy market penetration. Analysis and minimization of infrastructure losses and costs is especially important for early, successful hydrogen development because hydrogen production costs are expected to be initially high and because hydrogen infrastructure generally has higher costs and lower energy efficiency than conventional energy infrastructure (natural gas, gasoline, electricity).

Various yardsticks apply to each infrastructure issue. For example, a good measure of the scaie of a technology is the number of hydrogen vehicles or homes required to make it viable. Flexibility and vulnerability are both economic and physical issues and infrastructure options vary widely in their flexibility and vulnerability. Safety encompasses the dimensions of probability and magnitude of accidents. Energy efficiency is the fraction of final delivered energy used by the infrastructure to transform, transport, store, and deliver a unit of hydrogen energy. The separation of costs into capital, energy, and operating are important distinctions that make the assumptions of economic projections clear and subject to critical review.

Accomplishments/Status:

We have completed an outtine of the options for small-scale production and distribution to enable the beginnings of a transition to hydrogen vehicles. Emphasis has been on assembling technologies and costs for steps from production, through transportation and storage, to transfer to the vehicle. The data were assembled and analyzed on a uniform basis with regard to costs and the utilization system and technology and were differentiated as near-term, mid-term, and long-term technologies. The final product is consumer costs for various methods. We have examined electrolysis at the home with storage as compressed gas or metal hydride, and liquid hydrogen distribution to small fleets. Assuming that a home-size electrolysis unit can be purchased for $\$ 3500$, an individual hybrid-electric car can be operated for about $9 \$ / \mathrm{mile}$. This compares with $5 \% / \mathrm{mile}$ for a $25-\mathrm{mpg}$ conventional car operating on $\$ 1.25 / g a l l o n$ gasoline. For fleets operating on liquid hydrogen at today's prices, the operating costs drop to $4.5 \$$ to $6 \$ / m i l e$, depending on the exact cost of the hydrogen. Comparable costs operating on hydrogen reformed from natural gas at a small service station as estimated to be $4 \phi / m i l e$. We have supplied Energetics Inc. with the input data for pathways analysis of the scenarios studies.

Publications/Awards:

Berry, Gene D., Alan D. Pasternak, Glenn D. Rambach, J. Ray Smith, and Robert N. Schock, Hydrogen as a Future Transportation Fuel, LLNL Report UCRL-JC-117945 (1994).

Students associated with the Program (Undergraduate, Graduate, Post Doctoral):

Gene D. Berry (University of llinois, Urbana-Champagne)

Pamela Campus (Massachusetts Institute of Technology) 


\begin{tabular}{|c|l|l|l|l|l|}
\hline $\begin{array}{c}\text { Task } \\
\text { Titie }\end{array}$ & $\begin{array}{l}\text { Technical and Economic Assessments } \\
\text { of the Transport and Storage of } \\
\text { Hydrogen }\end{array}$ & Contractor & $\begin{array}{l}\text { Lawrence } \\
\text { Livermore National } \\
\text { Laboratory }\end{array}$ & $\begin{array}{c}\text { Principal } \\
\text { Investigator }\end{array}$ & Robert N. Schock \\
\hline
\end{tabular}

Future Directions/Industry Interactions:

\section{FY95 Efforts}

We will provide updated assessments of small-scale production options, emphasizing those that look most feasible and economic from the previous genera assessment. We expect to expand the assessment to include local station or fleet refueling using gas or liquid made by on-site steam reforming, electrolysis, or truck transport from a central production facility and to include various fleet and station technologies, such as natural gas direct conversion, mediated electrochemical oxidation, and high-temperature steam electrolysis, as well as steam-iron production and storage as ammonia. For steam reforming at a local station, we will rely on the analyses of Joan Olden at Princeton, also part of this DOE program. Regional effects, such as off-peak electricity or natural gas processes, will also be examined. Distribution variations - such as truck, rail, and ship - will be studied to examine the expansion of the hydrogen infrastructure and the practical economic paths likely to be followed.

\section{FY96 Efforts}

We will prepare a final report on infrastructure options for a transition to a hydrogen economy. This report will include up-to-date assessments for all phases of the infrastructure, with emphasis on the cost of the individual technical components and the delivered cost to the consumer. Data from other infrastructure studies will be incorporated. Analyses will be integrated with work at Princeton and Energetics inc., to provide balanced input into the Hydrogen Program Plan. 
System Studies 


\begin{tabular}{|c|c|c|c|c|c|c|c|c|}
\hline $\begin{array}{l}\text { Task } \\
\text { Thtie }\end{array}$ & \multicolumn{4}{|c|}{$\begin{array}{l}\text { Energy Pathway Analysis - Case } \\
\text { Studies }\end{array}$} & Contractor & $\begin{array}{l}\text { Energetics, } \\
\text { Incorporated }\end{array}$ & $\begin{array}{l}\text { Princlpal } \\
\text { Investlgator }\end{array}$ & Joseph S. Badin \\
\hline \multirow{2}{*}{$\begin{array}{l}\text { Task } \\
\text { Funding } \\
\text { (K\$) }\end{array}$} & FY91 & Fro2 & FY93 & FYS4 & \multirow{2}{*}{$\begin{array}{c}\text { Hydrogen } \\
\text { Program } \\
\text { Area }\end{array}$} & \multirow{2}{*}{$\begin{array}{l}\text { Life Cycle Cost } \\
\text { Analysis }\end{array}$} & \multirow[t]{2}{*}{ Researchers } & \multirow{2}{*}{$\begin{array}{l}\text { Phil DiPietro } \\
\text { George Kervitsky } \\
\text { Steve Mack }\end{array}$} \\
\hline & 0 & 0 & 0 & 100 & & & & \\
\hline
\end{tabular}

Objective:

To provide DOE with an analytical framework for the evaluation and screening of hydrogen pathways through the development of the Energy, Economics, Emissions (E3) Pathway and Network Analysis Models. To apply this framework to specific applications (case studies) of interest to the program, and to provide an objective and comprehensive assessment of the near-, mid-, and long-term competitiveness of hydrogen systems in those specific applications. Trade-offs, issues, and related information that affect the efforts to develop and commercialize hydrogen systems will be evaluated. Sensitivity studies will be performed to determine breakeven values for capital cost, efficiency, and values of externalities (emissions).

\section{Approach/Background:}

In order for hydrogen to gain commercial acceptance, in niche markets and in the national energy mix, hydrogen energy systems must compare favorably on an economic, efficiency, and environmental basis with competing energy carriers and systems. Each potential hydrogen application has a variety of performance requirements and a unique set of competing energy systems. The E3 Pathway and Network models have been developed in cooperation with DOE management, NREL, and the Hydrogen Technical Advisory Panel (HTAP) to provide a consistent basis in which to evaluate and compare the life-cycle costs, primary energy requirements, and emission impacts of different energy systems.

The E3 Pathway Analysis Model was developed to analyze energy systems that are comprised of a series of transformation steps or nodes (e.g., hydrogen production, storage, transport, end use). The cost of required capital equipment, annual operation cost, energy efficiency, and other performance data are estimated for each node and inputted to the model. The model calculates the capacity requirements and cost of each node per unit of energy consumed at the final stage, thereby determining the total amount of primary energy consumed (e.g., natural gas, biomass, solar insolation). The energy system's total present worth, annual cost, and the life-cycle cost are calculated. Pathway model results enable the program manager to compare competing energy pathways and identify specific critical technologies along an energy pathway that, because of low efficlency or high capital cost, drive the total cost of hydrogen energy use.

The E3 Network Analysis Model is a linear programming (LP) model that has been developed to study the interactions that occur with pathways that share common resources. The model combines all polential resource combinations from the E3 Pathway Analysis Model to create an energy lattice. The elements of the lattice, along with various end-use and activity constraining factors can be modified to create several scenarios that are evaluated using LP to determine the least-cost solution or pareto-optimum energy mix. Network Model results enable the program manager to evaluate the effects of government policies or incentives designed to accelerate the commercial penetration of hydrogen-based energy systems (e.g., placing a cap on emissions, or mandating a specific market share for renewable-based technologies). The Network Model can also analyze the effects caused by changes in the cost of fossil energy inputs due to carbon taxes or other measures of externalities.

The combined capabilities of the E3 Pathway and Network analysis models can be very useful in providing the Hydrogen Program management with key pieces of information to support decision making. These models ensure that all contributors to system cost, from primary energy consumption to end use, are considered when comparing different hydrogen technologies. Pathway analysis identifies financial information and component and system related life-cycle cost information for linear pathways based on the capital and operating costs and performance characteristics of system components. Network analysis identifies least-cost solutions to the simultaneous analysis of multiple pathway combinations and the resource/production/output constraints that may apply. Sensitivity analyses in both models estimate the magnitude of cost and efficiency improvements necessary to achieve cost parity with competing energy systems and identify emission values which improve the cost competitiveness of hydrogen technologies. In addition, the models allow analysis of the effect of changes in cost factors (e.g., capital, fuel, O\&M) and ultimately allow comparison of the commercial feasibility of hydrogen in different applications.

The E3 modeling systems provide information and detailed insights to help guide R\&D efforts to those components that drive the total cost of hydrogen systems. The program is able to set defensible cost and efficiency goals for R\&D projects that reflect the performance needed to achieve commercial penetration. Markets can then be targeted for industry outreach and demonstrations can be identified that hold the most promise for hydrogen technology. The models can help evaluate the impact that the introduction of such systems will have on costs, emissions, and the energy mix.

\section{Accomplishments/Status:}

A version of the E3 Pathway Analysis Model (version 2.0) has been finalized and submitted to the NREL. This version contains nominal cost and efficiency numbers for a comprehensive set of hydrogen production, management storage, transport, and end-use nodes and a library of 25 pathways previously defined in the Hydrogen Program Multiyear Plan FY 1993-1997. The model allows the user to vary costs and efficiencies to determine the impact they will have on the total cost of hydrogen production, delivery, and use.

A version of the E3 Network Model (version 1.0) has been finalized and submitted to NREL. The version submitted has the capabilities needed to generate, define, and analyze energy scenarios. Five scenarios (three modeling the utility sector, two modeling the transportation sector) have been developed, analyzed, and documented. 


\begin{tabular}{|c|c|c|c|c|c|}
\hline $\begin{array}{l}\text { Task } \\
\text { Thle }\end{array}$ & $\begin{array}{l}\text { Energy Pathway Analysis - Case } \\
\text { Studies }\end{array}$ & Contractor & $\begin{array}{l}\text { Energetics, } \\
\text { incorporated }\end{array}$ & $\begin{array}{l}\text { Princlpal } \\
\text { Investigator }\end{array}$ & Joseph S. Badin \\
\hline
\end{tabular}

Accomplishments/Status (continued):

In response to comments from the Hydrogen Program Review Committee, a Hydrogen Technology Cost and Performance Data base has been developed. The data base is a compendium of published cost and performance values associated with hydrogen production, storage, transport, and end-use technologies as well as conventional and renewable-based electricity generation technologies. The data base was presented to the Hydrogen Program System Studies Coordination Group, and comments have been incorporated. The data serve as the basis for inputs to the pathway analyses.

Pathway analysis has been applied to six specific hydrogen system applications. The six applications are as follows:

- A wind-powered electricity generation system for a remote village in Alaska. The wind-powered system contains an electrolyzer/fuel cell energy storage system to match the generation and load.

- A small $(2-3 \mathrm{~kW})$ electrolyzer installed at residential location fuels a vehicle powered by a hydrogen ICE/flywheel engine.

- A wind turbine/electrolyzer hydrogen production system provides fuel for a fleet of $10-20$ golf carts.

- A hydrogen bromine electrolyzer/fuel cell generates both off-peak electricity and hydrogen. In the hydrogen production mode, the electrolyzer/fuel cell operates in conjunction with a solar-powered hydrogen bromine reactor.

- Municipal solid waste is slurried and gasified to produce hydrogen gas to feed a fuel cell.

- Switchgrass is farmed and gasified to produce hydrogen gas for fuel cell generated electricity.

Energetics has compared and validated the estimated costs with parameter values contained in both the Cost and Performance data base and the literature. Research has been performed to identify pertinent competing energy systems for each application and to develop levelized life-cycle costs. For each of the six applications, a draft synopsis containing a cost estimate, sensitivity analysis, and a brief assessment was prepared.

Publications/Awards:

Recormmendation of Emission Values for the E3 Pathway Analysis Modeling System, Badin, J.S., Kervitsky, G., Energetics, Incorporated for DOE, October 1993.

Energy Pattway Analysis-A Hydrogen Full Cycle Framework for System Studies, World Hydrogen Energy Conference, Badin, J.S., Tagore, S., Energetics, Incorporated for DOE, January 1994.

Energy Pathway Analysis, U.S. DOE Hydrogen Annual Review Meeting, Badin, J.S., Kervitsky, G., Mack, S., Energetics, Incorporated for DOE, April 1994.

E3 Pathway Analysis Model Sensitivity Analysis Runs, Badin, J.S., Kervitsky, G., Energetics, incorporated for DOE, June 1994.

Technology Characterizations for the E3 Pathway Analysis-Cost and Performance Data base, Badin, J.S., DiPietro, J.P., Energetics, incorporated for DOE, June 1994.

E3 Network Analysis Model and User's Guide, Badin, J.S., Kervitsky, G., Mack, S., Energetics, Incorporated for DOE, August 1994.

E3 Pathway Analysis Model and User's Guide, Badin, J.S., Kervitsky, G., Mack, S., Energetics, Incorporated for DOE, August 1994.

Students associated with the Program (Undergraduate, Graduate, Post Doctoral):

None.

Future Directions/Industry interactions:

Final reports on the six pathways mentioned above will be submitted to DOE and the Hydrogen System Studies Coordination Group. Pathway analysis of additional applications will be performed as requested by the Hydrogen Program Manager.

The capability of the E3 Pattway Anatysis Model will be expanded to consider both the relative safety issues associated with hydrogen pathways and reliability of components in hydrogen systems.

The Hydrogen Technology Cost and Performance Data base will be updated on a periodic basis as information is received from published literature as well as from industry contacts.

The E3 pathway analysis framework abong with other state-of-the-art analytical tools will be utilized as part of the efforts under the International Energy Agency (IEA) Agreement Annex 11, integrated Systems, that is involved with data gathering from past and present demonstration projects, component modeling, and system design guidelines. 


\begin{tabular}{|c|c|c|c|c|c|c|c|c|}
\hline $\begin{array}{l}\text { Task } \\
\text { Title }\end{array}$ & \multicolumn{4}{|c|}{ Hydrogen Energy Systems Studies } & Contractor & Princeton University & $\begin{array}{l}\text { Princlpal } \\
\text { Investigator }\end{array}$ & Dr. Joan M. Ogden \\
\hline \multirow{2}{*}{$\begin{array}{l}\text { Task } \\
\text { Funding } \\
\text { (KS) }\end{array}$} & FY91 & FY92 & FY93 & FYr & \multirow{2}{*}{$\begin{array}{l}\text { Hydrogen } \\
\text { Program } \\
\text { Area }\end{array}$} & \multirow{2}{*}{$\begin{array}{l}\text { Life Cycle Cost } \\
\text { Analysis }\end{array}$} & \multirow[t]{2}{*}{ Researchers } & \multirow{2}{*}{$\begin{array}{l}\text { Dr. Eric Larson } \\
\text { Dr. Robert Williams }\end{array}$} \\
\hline & 50 & 50 & 130 & 130 & & & & \\
\hline
\end{tabular}

Objective:

For several years our group has carried out technical and economic assessments of hydrogen energy systems. The goal of this work has been to understand the potential for developing renewable hydrogen as an energy carrier for use in efficient low polluting end-use systems (such as fuel cells). Over the past year, we have explored how a transition toward eventual use of renewable hydrogen might begin by using hydrogen derived from natural gas.

\section{Approach/Background:}

To assess alternative pathways for producing and using hydrogen, we considered the entire energy system, estimating: 1) the cost and performance of hydrogen production systems, 2) the levelized cost of hydrogen production, 3) the cost of delivering hydrogen for various end uses, 4) the cost and performance of hydrogen end-use equipment, 5) the consumer's life-cycle cost of energy services, 6) environmental effects, 7) resource constraints, and 8) infrastructure issues. We have worked closely with researchers in industry, government and academia in developing the data for these studies.

Accomplishments/Status:

We have recently completed a study of the role of hydrogen from natural gas in a transition toward large-scale use of renewable hydrogen. In particular, we have 1) assessed various strategies for supplying hydrogen transportation fuel derived from natural gas, 2) examined the possibility of using pure hydrogen and hydrogen blends in the existing natural gas transmission, distribution and end-use systems, and 3) assessed the possibility of using PEM fuel cells fueled with hydrogen for residential congeneration.

Publications/Awards:

Ogden, J.M., "Hydrogen Energy Systems Studies," presentation to the U.S. DOE Hydrogen Systems Working Group, Princeton, NJ., February 8, 1994.

Ogden, J.M., E.D. Larson, and M.A. Delucchi, "Assessment of Renewable Transportation Fuels and Technologies, "Report to the U.S. Congress Office of Technology Assessment, March 1994.

Ogden, J.M., J. Strohbehn, and E. Dennis. "Hydrogen Energy Systems Studies," presented at the U.S. DOE Hydrogen Program Review Meeting, Livermore, CA, April 19-20, 1994.

Ogden, J.M., E. Dennis, and J. Strohbehn, "The Role of Hydrogen in a Transition to Hydrogen Transportation Fuel," presented at the 10th World Hydrogen Energy Conference, Cocoa Beach, FL, June 20-24, 1994.

Ogden, J.M., "Hydrogen Energy Systems Studies," presentation to the U.S. DOE Hydrogen Systems Working Group, Washington, DC, July 19, 1994.

Ogden, J.M., E.D. Larson, R.H. Wiliams, R. Katofsky, J. Chen, and M. Steinbugler, "Fuels for Fuel Cell Vehicles," presented at the Vice President's Meeting on Fuel Cell Vehicles, Partnership for a New Generation of Vehicles, Washington, DC, July 27, 1994.

Students associated with the Program (Undergraduate, Graduate, Post Doctoral):

None

Future Directions/Industry Interactions:

We are now beginning a study assessing technologies for small-scale production of hydrogen from natural gas. 


\begin{tabular}{|c|c|c|c|c|c|c|c|c|}
\hline $\begin{array}{l}\text { Task } \\
\text { Titie }\end{array}$ & \multicolumn{4}{|c|}{$\begin{array}{l}\text { Risks in Compressed Gas Storage - } \\
\text { Hydrogen versus Natural Gas }\end{array}$} & Contractor & Clean Energy & $\begin{array}{l}\text { Principal } \\
\text { Investigator }\end{array}$ & T. Nejat Veziroglu \\
\hline \multirow{2}{*}{$\begin{array}{l}\text { Task } \\
\text { Funding } \\
\text { (K\$) }\end{array}$} & FYos & FY92 & FY93 & FYre & \multirow{2}{*}{$\begin{array}{l}\text { Hydrogen } \\
\text { Program } \\
\text { Area }\end{array}$} & \multirow[t]{2}{*}{ System Safety } & \multirow[t]{2}{*}{ Researchers } & \multirow{2}{*}{$\begin{array}{l}\text { Michael R. Swain } \\
\text { Matthew N. Swain } \\
\text { Gregory J. Schade }\end{array}$} \\
\hline & 84 & 44 & 40 & 62 & & & & \\
\hline \multicolumn{9}{|c|}{ Objective: } \\
\hline \multicolumn{9}{|c|}{$\begin{array}{l}\text { This is a full-scale study to assess the risk of storing hydrogen in compressed form as opposed to storing natural gas in compressed form. Risk includes two } \\
\text { components: the likelihood of combustion and the severity of combustion. This study has direct applicability to vehicular storage and stationary storage of } \\
\text { hydrogen. }\end{array}$} \\
\hline \multicolumn{9}{|c|}{ Approach/Background: } \\
\hline \multicolumn{9}{|c|}{$\begin{array}{l}\text { During previous work, a comparison of hydrogen and natural gas pipeline leakage was made. Both the ignition tests and the computer modeling of the leakage } \\
\text { showed that the hydrogen clouds were smalier and contained less energy than did natural gas clouds. The present effort will determine if similar results are } \\
\text { found in leaks produced from ruptured compressed gas containers. }\end{array}$} \\
\hline \multicolumn{9}{|c|}{$\begin{array}{l}\text { The experiments consist of simulated tank ruptures as follows: compressed gas storage cylinders have been fitted with pneumatically actuated valves of } \\
\text { sufficient capacity to provide minimal restriction to the flow when open. The outlet side of each valve has been connected to an orifice (a simulated fractured } \\
\text { container wall) consistent with real world rupture geometries. Opening the valve initiates the leak, simulating tank rupture. The size of the resulting cloud of } \\
\text { hydrogen or natural gas will be quantified by testing ignitability at the periphery of the cloud with electric arcs, much the same way as has been done in previous } \\
\text { work. }\end{array}$} \\
\hline \multicolumn{9}{|c|}{ In addition, measurements of overpressure will be made and high-speed photography will be used to document the combustion. } \\
\hline \multicolumn{9}{|c|}{ Accomplishments/Status: } \\
\hline \multicolumn{9}{|c|}{$\begin{array}{l}\text { After the first four months of the project, the survey and review of applicable safety standards are complete. Infrared film and filters have been tested and film } \\
\text { selection has been made. The experimental apparatus has been designed and assembled. Initial testing indicated minor modifications should be made and } \\
\text { they are ongoing. The project is on schedule. }\end{array}$} \\
\hline \multicolumn{9}{|c|}{ Publications/Awards: } \\
\hline \multicolumn{9}{|l|}{ None } \\
\hline \multicolumn{9}{|c|}{ Students associated with the Program (Undergraduate, Graduate, Post Doctoral): } \\
\hline \multicolumn{9}{|c|}{ Graduate Student - Gregory J. Schade. } \\
\hline \multicolumn{9}{|c|}{ Future Directions/Industry Interactions: } \\
\hline
\end{tabular}




\begin{tabular}{|c|c|c|c|c|c|c|c|c|}
\hline Task & \multicolumn{4}{|c|}{ Supporting Analyses and Assessments } & Contractor & NREL & Principal & J. Ohi \\
\hline \multirow{2}{*}{$\begin{array}{l}\text { Task } \\
\text { Funding } \\
\text { (K\$) }\end{array}$} & FYs1 & FY92 & FYes & FYS4 & \multirow{2}{*}{$\begin{array}{l}\text { Hydrogen } \\
\text { Program } \\
\text { Area }\end{array}$} & \multirow{2}{*}{$\begin{array}{l}\text { Market Analysis and } \\
\text { Assessment }\end{array}$} & \multirow[t]{2}{*}{ Researchers } & \multirow{2}{*}{$\begin{array}{l}\text { N. Rau } \\
\text { S. Adelman } \\
\text { M.R. Szoka }\end{array}$} \\
\hline & 0 & 0 & 200 & 82 & & & & \\
\hline
\end{tabular}

Objective:

Provide a sound analytic foundation and focus for program planning, evaluation, and coordination by identifying and, where possible, quantifying program benefits and identifying transitional strategies for earty market penetration through industrial partnerships.

\section{Approach/Background:}

Participate and contribute to the comprehensive and coordinated effort in DOE/EE to identify and quantify program contributions to economic productivity, international competitiveness, and environmental quality. Develop a comprehensive set of metrics to measure the contributions of the Hydrogen Program to the overall mission of DOEJOEM and DOE/EE. Coordinate analysis with the integrated energy storage program in OEM, with the advanced propulsion and alternative fuels programs in the OTT, and with other relevant federal and non-federal programs. Work with the National Hydrogen Association and with industry to identify and facilitate near-term market opportunities for hydrogen production, storage, transport, and utilization.

Accomplishments/Status:

Prepared draft assessment of program benefits for fuel savings and emission reductions in the transportation, utility, and industrial sectors; developed analytic approach to assess the potential benefits of hydrogen production, storage, distribution, and use in a utility system; and began development of a systematic evaluation procedure for near-term hydrogen market opportunities.

Publications/Awards:

Draft benefits assessment for hydrogen use in the transportation, utility, and industrial sectors.

Students associated with the Program (Undergraduate, Graduate, Post Doctoral):

None

Future Directions/Industry Interactions

Work with selected utilities to develop comprehensive benefits analysis of hydrogen production, storage, transport, and utilization in a competitive utility market; work with industry to identify and evaluate near-term opportunities for hydrogen in all market sectors. 


\begin{tabular}{|c|c|c|c|c|c|c|c|c|}
\hline $\begin{array}{l}\text { Task } \\
\text { Title }\end{array}$ & \multicolumn{4}{|c|}{$\begin{array}{l}\text { Development of Industrial Interest in } \\
\text { Hydrogen }\end{array}$} & Contractor & $\begin{array}{l}\text { The National } \\
\text { Hydrogen }\end{array}$ & $\begin{array}{l}\text { Principal } \\
\text { Investigator }\end{array}$ & $\begin{array}{l}\text { Robert Mauro } \\
\text { Susan Leach }\end{array}$ \\
\hline \multirow{2}{*}{$\begin{array}{l}\text { Task } \\
\text { Funding } \\
\text { (KS) }\end{array}$} & FY91 & FY92 & FYos & FYoA & \multirow{2}{*}{$\begin{array}{c}\text { Hydrogen } \\
\text { Program } \\
\text { Area }\end{array}$} & \multirow{2}{*}{$\begin{array}{l}\text { Market Analysis } \\
\text { and Assessment }\end{array}$} & \multirow[t]{2}{*}{ Researchers } & \\
\hline & 0 & 50 & 20 & 150 & & & & \\
\hline
\end{tabular}

Objective:

The National Hydrogen Association (NHA) is working on activities that complement and support market analysis and assessment efforts to identify potential near-term markets for hydrogen technologies. The NHA is working with industry and other stakeholders to identify the institutional, regulatory, and nontechnical issues that must be resolved before commercial-scale markets for hydrogen emerge. The role that these constituencies want to play in developing mydrogen as a commercial fuel will be identified and assessed. Particular attention is being paid to the development of demonstration projects that have the potential for the formation of public/private partnerships.

\section{Approach/Background:}

The study approach is to work with industry, principally NHA members, to:

- Assess production, transport, and use of hydrogen by region

- Identify hydrogen consortia, describe their programs, and discuss participants' interests

- Determine NASA's interest in a hydrogen vehicle demonstration in the Southeast

- Examine supply and demand of hydrogen from the southeastern U.S. and southern California to determine the feasibility of a hydrogen pipeline

- Determine interest and identify a potential DOE role in consortium activities

- Categorize the nature of industry interest in hydrogen through NHA contacts.

\section{Accomplishments/Status:}

The NHA has surveyed the major hydrogen producers for information about the hydrogen market. Yearly output, consumption, use, and other current information such as the cost ranges for reforming hydrogen from natural gas and average amounts of hydrogen shipped via pipeline were investigated. The data collected from this survey are being used to update, extend, and supplement the information on hydrogen production and use in the Chemical Economics Handbook published by SRI. The survey also examined the present supply and demand of hydrogen in the south central states and southern California, and evaluated the potential of dispensing by-product hydrogen from the south central states to southern California.

Taking southem Califomia as a study area, the NHA is identifying the industries, organizations, utilities, potential users, and regulatory agencies with an interest in developing hydrogen as a fuel and energy storage medium. Near-term opportunities are being explored. In the course of these activities, the NHA seeks to identify specific roles for DOE in ongoing and proposed demonstration and commercialization activities that are compatible with the interests of the demonstration leaders.

Publications/Awards:

Leach, S. and R. Mauro, Opportunities for Hydrogen in the Energy Market, CryoGas International, November 1994.

Students associated with the Program (Undergraduate, Graduate, Post Doctoral):

None

Future Directions/Industry Interactions:

A workshop on Codes and Standards for Hydrogen Energy will be conducted in late January, 1995 to identify the code and standard requirements for hydrogen as an energy carrier. The emphasis will be on the transportation market. Safety experts, demonstration project participants, officials from federal agencies, and researchers will be brought logether to identify what needs to be done to put new codes and standards in place. Strategies to overcome the non-technical barriers to the commercialization of hydrogen-related technologies will also be addressed.

The NHA will provide a summary of industry review of the quality metrics developed by NREL. These quality metrics will compare the net energy and emissions benefits of hydrogen over fossil fuels.

The NHA has submitted a proposal for a grant to work with DOE to provide a procedure for the formation of partnerships between the National Hydrogen Program and industry to develop and commercialize hydrogen technologies. The following activities are proposed:

- Industry information exchange - includes activities such as expanding current NHA publications and initiating a quarterly newsletter, writing and publishing articles, providing funding to enable NHA to be represented at hydrogen-related meetings and workshops, and organizing industry review of DOE Strategic Plans and policy decisions. 


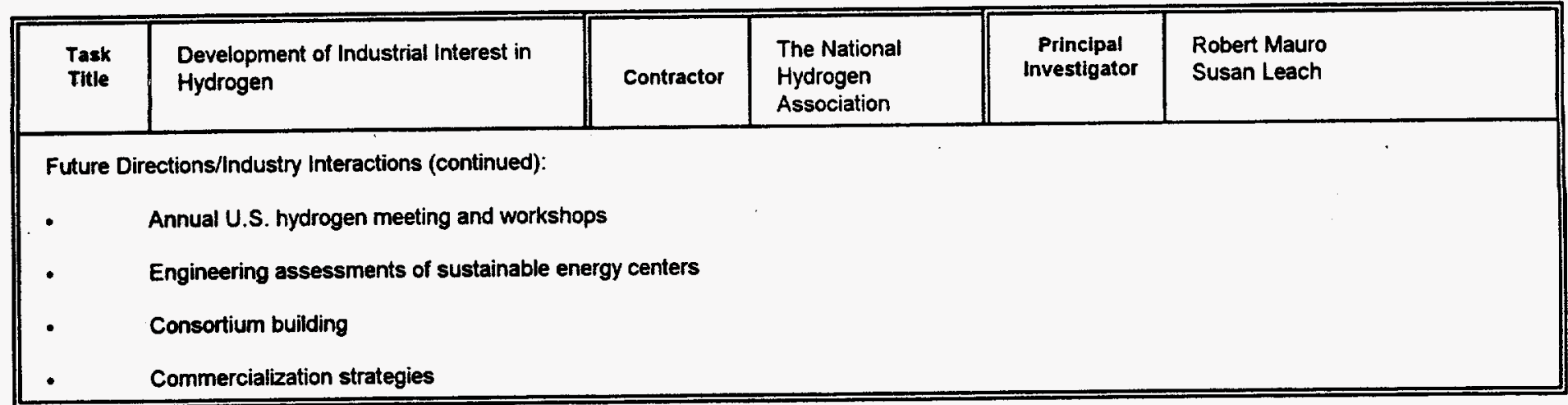




\begin{tabular}{|c|c|c|c|c|c|c|c|c|}
\hline $\begin{array}{l}\text { Task } \\
\text { Titte }\end{array}$ & \multicolumn{4}{|c|}{$\begin{array}{l}\text { Hydrogen Fuels Infrastructure } \\
\text { Development }\end{array}$} & Contractor & $\begin{array}{l}\text { Oak Ridge National } \\
\text { Laboratory }\end{array}$ & $\begin{array}{c}\text { Principal } \\
\text { Investigator }\end{array}$ & Suman P. N. Singh \\
\hline \multirow{2}{*}{$\begin{array}{l}\text { Task } \\
\text { Funding } \\
\text { (KS) }\end{array}$} & FY91 & FY92 & FY93 & FY94 & \multirow{2}{*}{$\begin{array}{c}\text { Hydrogen } \\
\text { Program } \\
\text { Area }\end{array}$} & \multirow{2}{*}{$\begin{array}{l}\text { Market Analysis and } \\
\text { Assessment }\end{array}$} & \multirow[t]{2}{*}{ Researchers } & \multirow[t]{2}{*}{ Andrea A. Richmond } \\
\hline & 0 & 0 & 0 & 200 & & & & \\
\hline
\end{tabular}

Objective:

To perform technical and economic assessments to develop the infrastructure requirements for a conceptual hydrogen fuel-dispensing station (similar to the present-day gasoline station) to provide fuel hydrogen for light-duty transportation vehicles.

\section{Approach/Background:}

The approach includes the following:

- Review industrial hydrogen production processes.

- $\quad$ Develop the design basis for a typical hydrogen-dispensing station for fueling light-duty transportation vehicles.

- Develop the process design and cost estimates for a grassroots, stand-alone, hydrogen-dispensing facility using the steam methane reforming and water gas shift conversion processes.

- Evaluate the regulatory and other permitting requirements for the conceptual stand-alone, hydrogen-dispensing station located in, for example, the Los Angeles basin in southern California.

Perform sensitivity analyses on the conceptual dispensing station design.

Prepare the technology assessment report on the hydrogen fuel-dispensing station study.

Background:

The transportation sector is a major user of fossitderived fuels and a major contributor of anthropogenic atmospheric emissions. Hydrogen-powered fuel cells are being studied as the prime movers for future transportation applications. Because of the projected increasing global demand for energy, the relatively limited supply of fossil fuels, and the heightening concerns regarding environmental pollution, hydrogen is being evaluated as an environmentally acceptable fuel to meet the growing energy demands of the future. However, there is no infrastructure for providing the hydrogen fuel. This study evaluates the infrastructure requirements for providing the hydrogen fuel for light-duty transportation vehicles thereby enhancing the viability of hydrogen as a preferred alternative to fossil-derived fuels for the future.

Accomplishments/Status:

The assessment was started in late May 1994. The study is presently on track and the following activities have been accomplished:

- Developed the basic premises for the stand-aione, small-scale grassroots hydrogen fuel-dispensing station.

- Completed the review and the design of the hydrogen production processes to provide the fuel hydrogen for the automotive dispensing station.

- Initiated a review of the potential regulatory and permitting requirements for the conceptual hydrogen fuel-dispensing station located in the Los Angeles basin in southern California.

Publications/Awards:

None

Students associated with the Program (Undergraduate, Graduate, Post Doctoral):

Ms. Kris Pleiss, graduate student

Mr. Jason Williams, undergraduate student.

Future Directions/industry Interactions:

The tectnology assessment report will serve as a guide for a prototype demonstration facility of a future dispensing station providing fuel hydrogen for light-duty transportation vehicles. This prototype facility is expected to be built to demonstrate hydrogen fuel production and dispensing capabilities to meet the needs of hydrogen-fueled, light-duty vehicles. These vehicles are expected to meet the zero emission vehicle (ZEV) requirements mandated by California for 1998 and beyond. The prototype facility is likely to be buit and operated as a joint venture between industry and relevant government agencies such as the Department of Energy (DOE), the Environmental Protection Agency (EPA), and the South Coast Air Quality Management District (SCAQMD) of California.

Extensive cooperation and consultations are being made with various relevant industrial organizations during the course of the assessment. A list of these organizations include Air Products, Praxair, International Fuel Cells, Ballard Power Systems, Hydrogen Burner Technology, Inc., Ford Motor Company, and General Motors. 


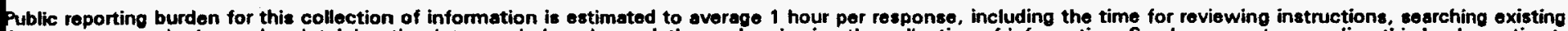

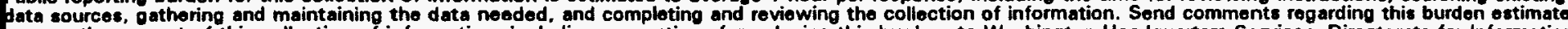

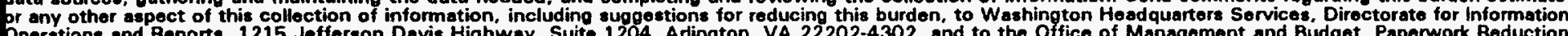

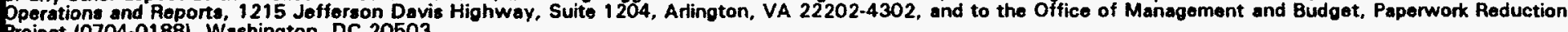
Project (0704-0188), Washington, DC 20503.

\begin{tabular}{|l|l|l|l}
\hline 1. AGENCY USE ONLY (Leave blank) & $\begin{array}{c}\text { 2. REPORT DATE } \\
\text { Merch } 1995\end{array}$ & $\begin{array}{l}\text { 3. REPORT TYPE AND DATES COVERED } \\
\text { Technical annual report }\end{array}$ \\
\hline
\end{tabular}

4. TITLE AND SUBTITLE

Hydrogen Program Summary: Fiscal Year 1994

AUTHOR(S)

Cathy Gregorie Padro, program manager

. PERFoRMING ORgANIZATION NAME(S) AND ADDRESSIES)

B. PERFORMING ORGANIZATION REPORT NUMBER

DE95004033

9. SPONSORING/MONITORING AGENCY NAME(S) AND ADDRESS(ES)

10. SPONSORING/MONITORING AGENCY REPORT NUMBER

National Renewable Energy Laboratory

1617 Cole Boulevard

NAEL TP-430-7752

Goiden, CO 80401-3393

\section{SUPPLEMENTARY NOTES}

\section{2a. DISTRIBUTION/AVAILABILITY STATEMENT}

National Technical Information Service

U.S. Department of Commerce

5285 Port Royal Road

Springfield, VA 22161

5. FUNDING NUMBERS

(C)

(TA) HY51.1010

\section{ABSTRACT (Maximum 200 words)}

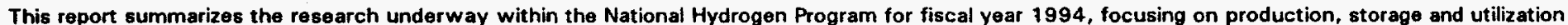
bf hydrogen.

\begin{tabular}{|c|c|c|c|}
\hline \multicolumn{3}{|c|}{$\begin{array}{l}\text { 14. SUBJECT TERMS } \\
\text { chemical reactions, hydrogen, utilities, electricity, fuel cells }\end{array}$} & \multirow{2}{*}{$\begin{array}{l}\text { 15. NUMBER OF PAGES } \\
\frac{56}{16 . \text { PRICE CODE }} \\
\text { A04 }\end{array}$} \\
\hline & & & \\
\hline $\begin{array}{l}\text { 7. SECURITY CLASSIFICATION } \\
\text { OF REPORT } \\
\text { Unclassified }\end{array}$ & $\begin{array}{l}\text { 18. SECURITY CLASSIFICATION } \\
\text { OF THIS PAGE }\end{array}$ & $\begin{array}{l}\text { 19. SECURITY CLASSIFICATION } \\
\text { OF ABSTRACT }\end{array}$ & 20. LIMITATION OF ABSTRACT \\
\hline
\end{tabular}

